\title{
ELEVERS ANVÄNDANDE AV FORMATIV ÅTERKOPPLING I MATEMATIK
}




\section{Studies in Science and Technology Education Nr 79}

Grafisk form omslag: Thomas Ottosson, Högskolan Kristianstad

Tryck: AM-tryck, Hässleholm 2014

ISSN 1652-5051

ISBN 978-91-7519-164-5

(c) Jenny Green 2014 


\section{JENNY GREEN ELEVERS ANVÄNDANDE AV FORMATIV ÅTERKOPPLING I MATEMATIK}

Högskolan Kristianstad, december 2014 Sektionen för lärande och miljö 

Till min familj 



\section{Innehållsförteckning}

$\begin{array}{ll}\text { INTRODUKTION OCH BAKGRUND } & 17\end{array}$

$\begin{array}{lc}\text { SKOLÄMNET MATEMATIK } & 18\end{array}$

$\begin{array}{lr}\text { FORSKARENS DRIVKRAFT } & 20\end{array}$

$\begin{array}{ll}\text { ÅTERKOPPLING } & 20\end{array}$

FORSKNINGSPROBLEMET $\quad 22$

STUDIENS SYFTE OCH FORSKNINGSFRÅGOR $\quad 22$

TEORETISKA UTGÅNGSPUNKTER OCH TIDIGARE FORSKNING 24

$\begin{array}{ll}\text { ÅTERKOPPLING } & 25\end{array}$

Hur återkoppling kan definieras $\quad 25$

$\begin{array}{ll}\text { Olika dimensioner } & 26\end{array}$

FORMATIV ÅTERKOPPLING $\quad 26$

$\begin{array}{ll}\text { Hur formativ återkoppling kan definieras } & 27\end{array}$

$\begin{array}{ll}\text { Återkoppling på fyra nivåer } & 27\end{array}$

Vad vi vet om hur elever använder återkoppling 29

Olika dimensioner $\quad 29$

FORMATIV ÅTERKOPPLING I MATEMATIK

De olika dimensionerna är applicerbara på formativ

återkoppling i matematik $\quad 33$

Vad vi vet om hur elever använder formativ återkoppling i matematik $\quad 35$

$\begin{array}{ll}\text { SJÄLVREGLERING } & 38\end{array}$

Hur olika perspektiv är integrerade med varandra 39

Har kontexten betydelse för självreglerat lärande? $\quad 41$

Hur situationen ser ut i matematikklassrum $\quad 42$

Kognitiva aspekter och motivationsaspekter är tydligast 43

MÅLORIENTERING I MATEMATIK $\quad 44$

Lärandemål och prestationsmål $\quad 44$

FAKTORER SOM INVERKAR PÅ ANVÄNDANDE AV FORMATIV ÅTERKOPPLING 47

Utmaningar med återkoppling att överbrygga $\quad 47$

Motivation $\quad 49$

Föreställningar som har betydelse för elevers motivation att

Den sociala dimensionen $\quad 55$

$\begin{array}{lr}\text { SLUTSATSER INFÖR FÖRELIGGANDE STUDIE } & 59\end{array}$

METOD OCH GENOMFÖRANDE

$\begin{array}{ll}\text { FORSKNINGSDESIGN } & 61\end{array}$

Val av skola och möte med klassen $\quad 62$

Utformande av intervjuguide och val av uppgifter 63

$\begin{array}{ll}\text { Test av intervjuguiden genom pilotstudie } & 63\end{array}$ 
$\begin{array}{ll}\text { Interventionsprov } & 64\end{array}$

Bearbetning av elevernas svar på interventionsprovet 66

Skriftlig återkoppling kompletterat med muntliga frågor 66

$\begin{array}{ll}\text { Ordinarie lärares prov } & 70\end{array}$

$\begin{array}{ll}\text { Urval } & 70\end{array}$

$\begin{array}{ll}\text { Djupintervjuer } & 71\end{array}$

HUR DEN NORMALA KONTEXTEN SER UT FÖR ELEVERNA

$\begin{array}{ll}\text { Klassen } & 72\end{array}$

$\begin{array}{ll}\text { Elevernas ambitionsnivå } & 72\end{array}$

Ordinarie lärares försök att arbeta med formativ bedömning 73

$\begin{array}{ll}\text { Sammanfattning av den normala kontexten } & 74\end{array}$

$\begin{array}{ll}\text { ANALYS } & 74\end{array}$

$\begin{array}{lr}\text { ETISKA FRÅGOR } & 77\end{array}$

$\begin{array}{ll}\text { RESULTATREDOVISNING } & \mathbf{7 8}\end{array}$

HUR ELEVERNA UPPLEVDE DEN FORMATIVA ÅTERKOPPLINGEN 80

Återkopplingen var användbar eftersom den hade fokus på vad de konkret behövde göra för att förbättra sina resultat $\quad 80$

Elevernas motivation ökade när de blev medvetna om sin nuvarande individuella situation $\quad 82$

Det var en ny situation för eleverna och de förstod inte syftet 83

Eleverna upplevde återkopplingen som skrämmande och de blev besvikna 85 $\begin{array}{ll}\text { Eleverna förstod inte återkopplingen } & 86\end{array}$

Eleverna upplevde det svårt att hantera återkopplingen 87

HUR ELEVERNA ANVÄNDE DEN FORMATIVA ÅTERKOPPLINGEN 89

Använder genom i huvudsak reflektion $\quad 89$

Läser och reflekterar inte $\quad 90$

ELEVERNAS MÅLORIENTERING I MATEMATIK

Lärandemål $\quad 92$

Prestationsmål $\quad 92$

HUR ELEVERNAS UPPLEVELSER, ANVÄNDANDE OCH MÅLORIENTERING SAMVERKAR 93

Kopplingar mellan hur eleverna upplevde och använde återkopplingen $\quad 94$

Kopplingar mellan målorientering och användande 96

Kopplingar mellan målorientering och upplevelser $\quad 99$

DE INFORMELLA SAMTALEN ÖVERENSSTÄMMER MED DJUPINTERVJUERNA 100

$\begin{array}{ll}\text { DISKUSSION } & 101\end{array}$

VILKEN BETYDELSE OLIKA ASPEKTER HAR FÖR ELEVERS ANVÄNDNING
AV FORMATIV ÅTERKOPPLING

$\begin{array}{ll}\text { Den individuella eleven } & 101\end{array}$

$\begin{array}{ll}\text { Återkopplingens karaktär } & 108\end{array}$

$\begin{array}{ll}\text { Kontexten eleverna befinner sig i } & 109\end{array}$ 
STYRKOR OCH SVAGHETER MED STUDIENS DESIGN OCH METODER

Styrkor

113

Svagheter

114

SUMMERANDE SVAR PÅ FORSKNINGSFRÅGORNA SAMT SLUTSATSER

118

IMPLIKATIONER FÖR UNDERVISNING OCH FORTSATT FORSKNING

119

REFERENSER

121

BILAGOR

137

BILAGA 1

137

Exempel 1

137

Exempel 2

138

BILAGA 2

142

Exempel 1

142

Exempel 2

143

BILAGA 3

147

Exempel 1

147

Exempel 2

148 



\section{Acknowledgements}

Jag vill rikta ett stort tack till de personer som gjort denna uppsats möjlig. Ett speciellt stort tack vill jag ge till mina handledare Kristina Juter, Anders Jönsson och Torgny Ottosson. Era kommentarer och utmanande frågor har varit så betydelsefulla. Jag vill även uttrycka ett stort tack till de diskutanter, Ingemar Holgersson och Mogens Niss, som läst texten under arbetets gång. Jag är tacksam för de givande diskussioner vi haft kring texten. Dessutom vill jag tacka läraren och eleverna som deltagit i studien, utan er hade detta varit omöjligt. Jag vill rikta ett särskilt tack till rektor Jörn Johansson och utvecklingschef Åsa Melkersson, båda Kristianstad kommun, för att ni möjliggjort för mig att genomgå dessa forskarstudier. Följande personer förtjänar även att omnämnas för sitt stöd, Maria Eriksson, Ingrid Lundh, Lotta Leden, Therese Granekull, Per Ranebo och Johannes Duelund samt LISMA-gruppen och personer kopplade till FontD. Slutligen vill jag även tacka min man Dan Green för det fantastiska stöd du bidragit med. 



\section{Abstract}

Students are often not satisfied with the feedback they receive, and do not always use it. Providing feedback on student learning has been shown to have a positive effect on learning, and is a key strategy in formative assessment. Students need to know (1) the goal, (2) their current level, and (3) the gap between these two, in order to advance towards the goal. In addition to receiving information about (1)-(3) above, students also need to actively engage with the feedback. In order to facilitate students' use of the feedback given, a sample of upper-secondary mathematics students in this study received formative feedback (i.e. non-evaluative, supportive, timely and specific). The purpose of this research was to examine how students experienced this formative feedback, how they used it, and how experience, usage and goal orientation interacted.

Data collection was done in the following steps. First, an intervention test with two calculation problems was given to the students. The answers were then handed in and processed based on theories of formative assessment and feedback. The students were given the formative feedback and, in order to capture their first impressions, they were asked how they perceived it. The next step was the regular teacher's test - to give the students an opportunity to use the feedback. Finally, in-depth interviews were conducted in order to study students' experiences of the formative feedback.

An attempt was made to find factors explaining why the students use, or don't use, their feedback. The students experienced the feedback in different ways, most notably finding the feedback useful, confusing or frightening. Some of these experiences indicate a view that assessment focuses on whether or not a mathematics question is answered correctly. Consequently, they view feedback as an extracurricular activity rather than as a learning situation. Some students seem to be able to overcome the contextual barriers and some do not even experience any barriers at all. The results suggest that it is essential to integrate feedback in the day-to-day instruction in order to increase the likelihood that all the students will derive benefit from it. 
Sökord: Upplevelse av återkoppling, målorientering, formativ återkoppling, återkoppling i matematik, självreglerat lärande. 
Figurer

\begin{tabular}{lll}
\hline Figur & Rubrik & Sida \\
\hline $\mathbf{1}$ & Tidslinje med genomförandesteg & 62 \\
\hline $\mathbf{2}$ & Interventionsprov & 65 \\
\hline $\mathbf{3}$ & Delar av formativ återkoppling som eleverna fick & 69 \\
\hline $\mathbf{4}$ & $\begin{array}{l}\text { Påverkansfaktorer hypotiseras genom elevernas upp- } \\
\text { levelser, vilka i sin tur eventuellt påverkar använd- }\end{array}$ & 79 \\
& ning & 98 \\
\hline $\mathbf{5}$ & De tre Elevprofilerna & 9 \\
\hline
\end{tabular}

\section{Tabeller}

\begin{tabular}{lll}
\hline Tabell & Rubrik & Sida \\
\hline $\mathbf{1}$ & $\begin{array}{l}\text { Sammanställning av elevernas upplevelser i olika } \\
\text { kategorier }\end{array}$ & 95 \\
\hline $\mathbf{2}$ & Antal elever i respektive kategori & 96 \\
\hline
\end{tabular}





\section{Introduktion och bakgrund}

Att mäta, bedöma och betygsätta enskilda människors prestationer och även samhälleliga företeelser är inget nytt. Man kan se den ökade användningen av utvärderingar och bedömningar som ett sätt att driva utvecklingen framåt. Idag framhålls vikten av att noggrant följa, kontrollera och värdera prestationer. Inom skolan är dessa prestationer relaterade till kunskap och vi talar om kunskapssamhälle och livslångt lärande.

Idag brukar man skilja på två olika syften med bedömning: Summativ bedömning, som har som syfte att ta reda på vad eleven har lärt sig hittills och formativ bedömning, vars syfte är att utveckla elevens lärande. Det handlar alltså inte om att formativ och summativ bedömning är två olika sorters bedömning utan skillnaden ligger i hur bedömningen används. Formativ bedömning karaktäriseras av att målet för undervisningen är känt för eleven och att man tar reda på var eleven befinner sig i förhållande till målet och ger återkoppling på hur eleven kan minska skillnaden mellan målet och den egna nivån. Formativ bedömning har visat sig vara effektivt när det gäller att höja elevers prestationer (Black \& Wiliam, 1998). Wiliam (2010) har identifierat fem nyckelstrategier inom formativ bedömning: Tydliggöra mål och kriterier för framgång, skapa aktiviteter som synliggör lärandet, ge återkoppling som för lärandet framåt, aktivera eleverna som läranderesurser för varandra och aktivera eleven till att äga sin egen lärprocess. Fokus för denna studie riktas mot formativ återkoppling som har för avsikt att föra lärandet framåt i ett matematikklassrum på gymnasiet. Jag undersöker vad som händer om gymnasieelever får en formativ återkoppling i matematik, vilken borde (i alla fall enligt teorier om formativ återkoppling) gynna eleverna i deras lärande. Kommer eleverna att använda återkopplingen eller finns där andra faktorer, så som tidigare upplevelser och känslor som kanske påverkar hur de tar emot och använder sig av återkopplingen?

Vad gäller återkoppling med avseende på elevers lärande finns ett flertal studier gjorda. Ett antal forskningsöversikter och metaanalyser bekräftar att återkoppling är centralt för lärande (Black \& Wiliam, 1998; Hattie, Biggs \& Purdie, 1996) och Ramsden (2003) argumente- 
rar för att effektiva kommentarer på elevers arbete utgör en av huvudfaktorerna för god undervisning. Enligt Yorke (2003) är det inte bara återkopplingens innehåll som är av vikt utan det krävs även en medvetenhet kring psykologin om att ge och få återkoppling avseende elevers lärande. Det finns många olika faktorer som kan påverka elevers användning av en återkoppling, till exempel faktorer relaterade till läraren, återkopplingens innehåll, hur den levereras, dess sammanhang, timing och eleverna själva (Jönsson, 2012). Även Wiliam (2010) skriver att det inte endast är kvaliteten på återkopplingen som är av vikt, utan läraren och den lärandemiljö i vilken återkopplingen ges och tas emot spelar också roll (Black \& Wiliam, 2006; 2009). För att återkopplingen ska vara effektiv måste den vara begriplig, komma i rätt tid och eleverna måste dessutom agera på den (Gibbs \& Simpson, 2004). Trots dess potential kan man i forskning se att elever ofta är missnöjda med den återkoppling som de får. Detta för att den ofta saknar specifika råd för förbättring av studieresultaten (Higgins, Hartley \& Skelton, 2001), men även för att studenterna ${ }^{1}$ tycker att återkopplingen är svårtolkad (Chanock, 2000) samt att den dessutom kan ha ett negativt inflytande på deras självuppfattning och självförtroende (James, 2000).

\section{Skolämnet matematik}

På grund av dess speciella symbolspråk är matematiken annorlunda än andra ämnen. Inom matematiken använder man speciella ord och uttryck som kan vara förvirrande för elever, till exempel ord som har en eller flera betydelser, användandet av metaforer, eller att matematiska uttryck ska vara så koncisa som möjligt. En del av lärarens roll är att förmedla mellan matematikens diskurs och den diskurs eleven befinner sig i så att eleven kan använda det matematiska språket för att frambringa matematiska idéer och för att utforska dessa (Lee, 2006). När läraren hjälper dem att göra detta kan elevers lärande markant förbättras (ibid). Ett sätt är att ge eleverna formativ återkoppling. En återkoppling bör hjälpa till med att svara på frågorna: (1) Vad är målet? (2) Var befinner sig elevens prestation i förhållande till målet

\footnotetext{
${ }^{1}$ I föreliggande studie används både begreppet elever och studenter eftersom såväl litteratur inom högre utbildning som litteratur inom utbildning för lägre åldrar presenteras.
} 
samt (3) Hur ska eleven förbättra prestationen i riktning mot målet (Hattie \& Timperley, 2007)?

Bland elever på gymnasiet finns det stora skillnader i hur de upplever skolämnet matematik (Skolverket, 2003). Det finns:

- Elever som känner glädje och intresse då de plötsligt förstått matematiken genom att de lärt sig rutiner för problemlösning och fått djupare insikt i matematikens begrepp och metoder.

- Elever som inte vill ge ämnet en chans när de kommer till gymnasiet eftersom de har dåliga erfarenheter med misslyckanden och oförståelse, som "dödat motivationen".

- Elever som tycker att det är viktigt att lära sig matematik till en viss del, men som inte tror de klarar av det.

- Elever som väljer bort matematik eftersom de ger upp och tycker att det är ett ämne för andra, även om de inser att det är ett viktigt ämne.

Skolinspektionens rapport från 2009 visar att skillnaderna ökar ju högre upp i skolsystemet man kommer mellan de som förstår och har tillit till den egna förmågan och de som inte förstår och som därmed förlorat både tilltron till den egna förmågan att lära sig matematik och lusten till att lära sig. Bland högstadie- och gymnasieelever är det främsta skälet till att lära sig matematik betyg och poäng (dvs. prestationsinriktning på lärandet) och många elever verkar vara omotiverade och uttråkade eftersom det $\mathrm{i}$ undervisningen saknas en miljö som skapar motivation och en lust till att lära sig matematik (Skolinspektionen, 2009).

För att en undervisningssituation ska bidra till att eleverna blir engagerade och intresserade måste det finnas utrymme för "både känsla och tanke, upptäckarglädje, engagemang och aktivitet hos både elever och lärare" (Skolverket, 2003, s. 14). Ett bra samspel mellan engagerade och kunniga lärare och deras elever leder till att innehållet $i$ skolmatematiken upplevs relevant och begripligt. Ett bra samspel leder också till en känsla av att lyckas hos eleverna, som leder till personligt växande och ökad självtillit. För att påverka motivationen till att vilja lära sig är det viktigt att känna att man kan och förstår, att man lyckas, att det finns en tilltro till den egna förmågan att lära sig 
och att man lär sig (Bandura, 1994, 1997). Även Skolinspektionens granskning (2009) visar empiriskt tydliga samband på detta. Elever som ständigt möter misslyckanden i matematik förlorar snabbt motivation och en vilja till att lära sig. Därför är det viktigt att misstag och otillräckliga lösningar behandlas som naturliga delar i lärandet (Kloosterman \& Gorman, 1990) och då kan en formativ återkoppling ha en stor betydelse.

\section{Forskarens drivkraft}

Jag är själv verksam lärare sedan några år tillbaka och denna forskarresa startade med en känsla av att jag inte bedömde mina elever rättvist då det som de gjorde långt innan betyg skulle sättas, påverkade deras slutliga betyg. Jag ville se en lärandeprocess, en utveckling där varje elev var delaktig. Där eleverna själva kunde se vad som förväntades av dem, där de själva kunde följa sin utveckling och därmed se sin egen progression. Att lära matematik är en aktiv process och ingen utantillkunskap, begreppen hänger samman och kontinuitet är viktigt (Hiebert \& Lefevre, 1986). Med detta i tankarna växte användandet av ett nytt bedömningssätt fram för oss kollegor på skolan. Vi använde oss av en analytisk bedömning där delarna av processen eller produkten bedömdes var för sig. Eleverna bedömdes på varje enskilt moment som förekommer inom matematikämnet och respektive kurs. Vi satte sedan inte ut några betyg på respektive del eftersom om den analytiska bedömningen summeras till en poängsumma eller ett betyg, förloras informationen om resultatet, som i detta fall måste anses vara det väsentliga. Detta väckte ett visst motstånd hos eleverna och vi tyckte inte det gav upphov till ett så stort engagemang hos dem som vi önskat. Min nyfikenhet på varför eleverna reagerade som de gjorde blev början på föreliggande forskning.

\section{Återkoppling}

Att ge en högkvalitativ återkoppling som för lärandet framåt borde ligga i linje med alla lärares tankar kring bedömning. Men hur en sådan återkoppling ska se ut och hur den bör levereras till eleverna för att den verkligen ska gynna dem i deras lärande är inte helt självklart. Förutom att återkopplingen bör vara kvalitativ krävs det också att ele- 
verna reagerar på och använder denna återkoppling på ett konstruktivt sätt.

Sadler (1989) anser att återkoppling är det viktigaste inslaget i bedömning för lärande ${ }^{2}$. För att ha så stor nytta som möjligt av en bedömning måste en elev veta vad hon ${ }^{3}$ ska göra för att komma $\mathrm{i}$ fatt eller komma vidare. Eleven har ingen nytta av att bara veta att hon "ligger efter" (Lindström, 1995). Det finns undersökningar som visar att enbart information om utfallet, till exempel i form av betyg, inte främjar lärandet (Black, Harrison, Lee, Marshall, \& Wiliam, 2003; Kluger \& DeNisi, 1996). För att eleven successivt ska kunna ta ett ökat ansvar för det egna lärandet är det viktigt att lärare och elev i stort sett har samma uppfattning om vad som utgör kvalitet i en uppgift. Under arbetets gång är det även viktigt att eleven kan jämföra den aktuella kvalitativa nivån med den hon önskar nå upp till (Sadler, 1989). Idag bör inte bedömningen fokusera på att eleven ska kunna reproducera minneskunskaper som är rätt eller fel, utan idag bör det istället mer fokuseras på vilken kvalitet som eleven kan visa i sina kunskaper (Kjällström, 2005). Detta sätt att se på bedömning stöds av de läroplaner, bedömningens inriktning och de kunskapskrav som vi har nu.

För att klara denna typ av bedömning behövs nya bedömningsredskap och det är mycket viktigt hur en bedömning förmedlas. Eftersom information om resultatet försvinner då resultaten från olika typer av uppgifter vägs samman eller bara summeras, beskrivs information (om resultat av bedömningar) bäst med någon typ av profil. Resultat $\mathrm{i}$ form av en ensam siffra eller bokstav ligger långt ifrån en strävan att beskriva elevers prestationer i termer av vad de kan och det visar inte komplexiteten i det som avses bedömas (Gipps, 1994). Därför måste vi söka alternativa vägar att presentera resultat från en bedömning (Kjellström, 2005). Denna studie undersöker ett sätt att bedöma elevers prestationer som är en del i processen. Min strävan är att försöka

\footnotetext{
${ }^{2}$ Bedömning för lärande handlar om att anpassa bedömningen till läroplanens mer komplexa mål genom till exempel bedömningsmatriser, öppna frågor, framåtsyftande återkoppling, kamratbedömning och självrättning (Lundahl, 2011).

${ }^{3}$ För att få flyt $\mathrm{i}$ texten har jag valt att skriva hon/henne istället för att skriva hon/han eller henne/honom.
} 
beskriva och förstå elevers upplevelser av en bedömning, en formativ återkoppling.

\section{Forskningsproblemet}

Återkoppling nämns ofta i artiklar som handlar om lärande och undervisning, men förvånansvärt få studier har systematiskt undersökt återkopplingens betydelse och vad det är som pågår i klassrum gällande återkoppling (Hattie \& Timperley, 2007). Effektiv återkoppling har en kognitiv påverkan genom att hjälpa eleverna att förstå var de befinner sig i sitt lärande och vart de behöver ta sig härnäst. Återkoppling kan även ha en motiverande effekt genom att hjälpa eleverna att utveckla en känsla av kontroll över sitt eget lärande (Brookhart, 2007). Men för att dessa effekter ska uppstå måste eleverna vara engagerade och verkligen använda den återkoppling de får. Det räcker alltså inte att återkopplingen innehåller "perfekt information", utan också att eleverna faktiskt använder sin återkoppling.

Jönsson (2012) skriver att studenters mottagande och användande av återkoppling inte är väl undersökt. Även Hounsell (2003) skriver att det finns få tillgängliga studier på återkoppling och att de saknar djup. Hounsell hävdar också att det saknas en djupare insikt kring studenters strategier för användande av återkoppling och de faktorer som påverkar deras användande.

Enligt tidigare forskning vet vi att eleverna inte alltid är engagerade och tar till sig den återkoppling som de får (Brown \& Glover, 2006; MacDonald, 1991; MacLellan, 2001). Dock så kan återkoppling vara det som har mest inverkan på inlärningsprocessen (Hattie, 2009). Denna inverkan kan vara av både negativ och positiv karaktär, det vill säga både hindra och stödja lärande (Kluger \& DeNisi, 1996).

\section{Studiens syfte och forskningsfrågor}

Syftet med denna studie är att undersöka hur elever upplever en formativ återkoppling och hur de använder den. Elevernas mål med skolmatematiken (s.k. målorientering) identifieras eftersom denna visat sig ha betydelse för deras agerande $\mathrm{i}$ undervisningen (Ames, 1992; Pintrich \& De Groot, 1990). Vidare görs kopplingar mellan 
elevernas målorientering, deras upplevelser och hur de använder återkopplingen. Avsikten är att hitta mönster genom att identifiera och beskriva specifika kännetecken/särdrag av elevernas upplevelser av återkopplingen, att kategorisera dessa mönster och försöka se skillnader samt likheter i upplevelserna.

Studien syftar till att belysa följande frågeställningar:

- Hur upplever eleverna en formativ återkoppling?

- Hur använder eleverna en formativ återkoppling?

- Hur samverkar elevernas upplevelser, hur de använder återkopplingen och deras målorientering? 


\section{Teoretiska utgångspunkter och tidigare forskning}

I detta kapitel presenteras och redogörs för studier och teorier som berör olika faktorer som verkar påverka elevers upplevelser av formativ återkoppling samt deras möjligheter till användande av återkoppling och därmed deras lärande i matematik. Begrepp som presenteras är självreglering, målorientering och motivation. Motivation kopplas i sin tur till affektiva upplevelser (såsom förväntningar och självförtroende), föreställningar och till en social dimension i form av didaktiskt kontrakt och sociomatematiska normer. Valet av denna litteratur är gjord eftersom dessa aspekter har betydelse för hur elever använder sin återkoppling. Inledningsvis ges en presentation av litteratur om återkoppling generellt, som är ett område som är oerhört omfattande. Forskningen inom området har tagit avstamp i flera olika lärandeteorier samt delvis förmedlat motstridiga resultat (Shute, 2008), vilket gjort det svårt att göra en kort och koncis litteraturgenomgång. Därefter ges en presentation av litteratur om formativ återkoppling. I litteraturgenomgången görs en åtskillnad mellan utformning av återkoppling och hur återkopplingen används. Både litteratur inom högre utbildning och litteratur inom utbildning för lägre åldrar presenteras eftersom återkoppling handlar om liknande processer i lärandet oavsett stadium. Litteratur har valts för att kunna resonera kring vad som definierar god återkopplingspraktik och presenteras tillsammans med forskning kring elevers upplevelser och hur de använder sin återkoppling även om sådana studier inte är många till antalet (Jönsson, 2012). Det har inte heller varit lätt att hitta något om återkoppling med formativt syfte i matematikklassrum. Istället har annan forskning hittats, som jag kan dra paralleller till i föreliggande studie och som inneburit integrering av olika perspektiv. I den matematikdidaktiska forskningen behövs fokus på matematikens innehåll i sig, elevers förståelse av detta innehåll, hur innehållet hanteras i undervisningen och på de aspekter som rör klassrum utifrån ett matematikperspektiv (Björklund Boistrup, 2012). I föreliggande studie handlar det om att utifrån ett matematikklassrum få ökad förståelse av elevers upplevelser och användande av formativ återkoppling i ämnet.

Återkoppling presenteras i förhållande till matematiklärande och undervisning. När litteratur sökts har följande frågor varit vägledande: 
Vad för särskilda möjligheter och hinder/svårigheter finns det för formativ återkoppling i just matematik? Det finns ett antal viktiga förutsättningar för att elever ska ta till sig återkoppling och förbättra sina prestationer, men hur ser relationen ut mellan dessa förutsättningar å ena sidan och mellan matematiklärande och -undervisning å den andra? Teorier och studier om lärande i matematik presenteras för att visa vilka specifika möjligheter och svårigheter det finns med att ge återkoppling i matematik.

\section{Återkoppling}

Återkoppling i utbildningssammanhang är information om resultatet av en bedömning och kan se ut på många olika sätt. Beroende på hur återkopplingen ser ut påverkas elevernas fortsatta lärande på olika sätt. Nedan följer hur återkoppling kan definieras samt en diskussion kring vad återkoppling kan vara.

\section{Hur återkoppling kan definieras}

Enligt Hattie och Timperley (2007) kan återkoppling beskrivas som information som tillhandahålls av en agent (t.ex. lärare, eleven själv, kamrat, bok) avseende aspekter av en individs prestation eller förståelse. Det huvudsakliga syftet är att minska skillnaden mellan den nuvarande förståelsen eller resultatet och den önskade nivån på prestationen eller målet.

Sadlers (1989) definition av återkoppling skiljer sig från den ovan nämnda definitionen av Hattie och Timperly (2007) genom att hävda att det inte existerar någon återkoppling om eleven inte använder sig av informationen. Hattie och Timperley (2007) relaterar återkoppling till de tre frågorna: "Vad är målet?", "Var befinner sig elevens prestation i förhållande till målet?" samt "Hur ska eleven förbättra prestationen i riktning mot målet?". När både lärare och elever söker svar på dessa frågor kan en idealisk miljö för lärande uppstå. Enligt Brown (2007) är återkoppling ett sätt att delge viktiga kommentarer som kan bli till nytta för studenter genom att skapa medvetenhet om hur man kan/bör göra ("självreflekterande process"). I föreliggande studie används återkoppling i enlighet med Hattie och Timperleys (2007) definition tillsammans med en önskan om att återkopplingen används (enligt Sadlers definition, 1989). 


\section{Olika dimensioner}

Återkoppling kan beskrivas i ett antal dimensioner, varav några kan vara:

- Sändare

- Mottagare

- Överföringsmetod

- Innehåll

- Tidsaspekt

- Kontext

Enligt Jönsson (2013) kan exempel på andra sändare vara kamrater, datorer och matriser. Avseende mottagare har eleverna olika behov och kan därmed anses representera multipla mottagare. Även läraren kan vara mottagare. Överföringsmetod kan vara muntlig, skriftlig, grafisk och så vidare och de sistnämnda kan ske såväl i pappersform som elektroniskt. Innehållet kan variera i det oändliga och kan vara kort, omfattande, numeriskt, med eller utan betyg, specifikt, allmänt, personligt, uppgiftsrelaterat och så vidare. Återkopplingen kan ha olika tidsaspekt beroende på om den kommer direkt eller fördröjd, oftast kopplat till hur omfattande en uppgift är, och relatera till en eller flera tidpunkter bakåt i tiden. Kontext i vilken återkopplingen ges kan vara klassrum, andra lärandemiljöer, olika ämnen, årskurser och skolformer.

\section{Formativ återkoppling}

Formativ återkoppling har sin utgångspunkt i den bedömning som görs av elevens prestation eller förståelse. Återkoppling bör innehålla information som eleven kan använda och den bör präglas av en dialog mellan elev och lärare där fokus riktas mot hur eleven ska komma vidare i sin utveckling (Wiliam, 2010).

Formativ återkoppling syftar till att överbrygga skillnaden mellan var eleven befinner sig och målet. Således måste eleven känna till både sin nuvarande situation och målbilden. Forskning presenterar motstridiga resultat gällande återkoppling eftersom det finns många olika faktorer som kan påverka ifall effekten blir stark eller svag, vilket gör 
det svårt att säga hur en återkoppling bör se ut. Däremot finns det vissa indikationer på hur återkoppling bör utformas, vilken information den bör innehålla och när den bör ges för att effektivt stödja elevers utveckling. Nedan följer en presentation av hur formativ återkoppling kan definieras samt hur den kan se ut.

\section{Hur formativ återkoppling kan definieras}

Shute (2008) definierar formativ återkoppling som "information communicated to the learner that is intended to modify his or her thinking or behavior for the purpose of improving learning" (s. 154). I den här definitionen ligger det underförstått en aktiv handling som utförs av eleven genom att det förutses att eleven använder återkoppling för att förbättra sina prestationer. Dock koncentrerar sig både Shute (2008) och Hattie och Timperley (2007) mycket på själva informationen (t.ex. vad återkopplingen bör innehålla för information och hur den bör vara utformad). Kvaliteten på återkopplingen är en nyckelfaktor i den formativa bedömningsprocessen och har stor betydelse för undervisningens kvalitet. Återkoppling kan vara ett av de mest kraftfulla pedagogiska verktyg som påverkar elevers lärande och prestation (Black \& Wiliam, 1998; Hattie \& Timperley, 2007). Eleverna kan använda informationen i återkopplingen för att förbättra sina prestationer och lärarna kan använda informationen i beslut om undervisningen (Black \& Wiliam, 1998; Sadler, 1989). Däremot framträder inte elevens roll i dessa forskares artiklar (Sadler, 1989; Wiliam, 2011). I föreliggande studie används begreppet formativ återkoppling med fokus på hur vi kan få eleverna att använda sin återkoppling och den kombinerar de faktorer som i tidigare studier visat sig vara fördelaktiga för elevers lärande (om än i laboratoriekontext).

\section{Återkoppling på fyra nivåer}

Hattie och Timperley (2007) hävdar att det finns fyra huvudsakliga nivåer av återkoppling som gör skillnader för elevers lärande. Återkopplingen kan ges på uppgifts-, process-, metakognitiv (självregleringsnivå enligt Hattie och Timperley, 2007) respektive personlig nivå. 


\section{Återkoppling på uppgiftsnivå}

För att en återkoppling ska kunna stötta elever i sitt lärande behöver den tydligt vara kopplad till uppgiften och inte vara för abstrakt eller generell (Shute, 2008). Allt för mycket återkoppling på uppgiftsnivå kan medföra att elever fokuserar på kortsiktiga mål istället för att ha mer långsiktiga strategier (Hattie \& Timperley, 2007). Istället behöver återkoppling på denna nivå kombineras med en inriktning på de processer som eleven använder för att fullgöra en uppgift. Denna kombination gör återkopplingen mer effektfull genom att den då i högre utsträckning är generaliserbar till andra uppgifter än den uppgiftsrelaterade återkopplingen (Hattie \& Timperley, 2007).

\section{Aterkoppling på processnivå}

Björklund Boistrup (2010) har i linje med Hattie och Timperley (2007) visat att återkoppling som fokuserar på processer (vad som krävs, det vill säga strategier för att lösa en uppgift i matematik) medför goda förutsättningar för elevers lärande. Enligt Jönsson (2010) är processrelaterad återkoppling en nyckelfaktor inom formativ bedömning då den skapar grundläggande förutsättningar för förbättring av prestationer genom att tydliggöra kvaliteter i återkommande aktiviteter.

\section{Aterkoppling på metakognitiv nivå}

Den metakognitiva återkopplingen syftar till att stärka elevens förmåga till att utvärdera sina framgångar, reglera sitt lärande samt till att motivera sig själv. Det kan innebära att utveckla strategier för självbedömning och självdisciplin samt att stärka elevens förmåga till att själv ta ansvar för att få återkoppling.

\section{Aterkoppling på personlig nivå}

Enligt Hattie och Timperley (2007) är det vanligt med återkoppling på personlig nivå, men det är inte effektivt för att förbättra elevers prestationer. Bedömningshandlingar med fokus på eleven själv eller på uppgiften ger inte samma förutsättningar för elevers lärande, eftersom de då inte uppmuntras till att använda matematikens semiotiska resurser (symboler, gester, tal och liknande; Björklund Boistrup 2010; Hattie \& Timperley, 2007). Personlig återkoppling inriktar sig på eleven som person och svarar inte på frågan vad eleven måste göra för att nå de aktuella målen. Beröm utan förklaring (såsom "bra jobbat") är ett 
exempel på denna typ av återkoppling och är ineffektivt avseende att stärka elevers lärande och kan till och med ha en negativ effekt på prestationer.

\section{Vad vi vet om hur elever använder återkoppling}

Det finns belägg på att många studenter inom högre utbildning inte använder den återkoppling som de får och alltså inte utnyttjar den potential som återkoppling kan ha (Jönsson, 2012). Enligt Brown och Glover (2006) uppskattar studenter att få återkoppling, men deras forskning tyder på att studenter inte agerar på den. Vidare skriver Maclellan (2001) att studenter inte använder bedömning för att förbättra sitt lärande. Mindre än hälften av studenterna i en studie gjord av Sinclair och Cleland (2007) brydde sig om att hämta ut sin formativa återkoppling. Från en litteraturöversikt av återkoppling drar MacDonald (1991) slutsatsen att många studenter inte läser sina lärares skriftliga återkopplingar och de som gör det använder dem sällan som guide för att revidera sitt arbete eller sina uppgifter. Dessutom visar MacDonalds studie att studenters huvudsakliga intresse är vilket betyg de fått på en given uppgift och inte lärarens kommentarer.

\section{Olika dimensioner}

Formativ återkoppling kan beskrivas $\mathrm{i}$ ett antal dimensioner, varav några kan vara (Shute, 2008; Hattie \& Timperley, 2007):

- Specifik, men inte för specifik

- Kopplad till en specifik uppgift

- Framåtsyftande

- Begriplig

- Levererad i rätt tid

- Individuellt anpassad

- Icke-värderande (ej poäng, betyg, levererad i form av matris)

Det är utifrån denna forskning som återkopplingen i föreliggande studie formulerats. Den beskrivs mer utförligt i kapitlet Metod och genomförande. 
Specifik, men inte för specifik och kopplad till en specifik uppgift Shute (2008) poängterar att återkoppling bör vara specifik, tydlig och att den relaterar till målen för att inte hindra eleverna i deras lärande. Därför behöver återkoppling tydligt kopplas till uppgiften och inte vara för abstrakt eller generell. Exakt hur specifik återkopplingen bör vara är beroende på typ av uppgift och hur eleven förväntas använda återkopplingen. Återkoppling som är för specifik kan leda till att den inte känns användbar eftersom eleven då kan känna att återkopplingen inte är återanvändbar för andra uppgifter, vilket därmed kan leda till att eleven inte behöver tänka själv. Specifik återkoppling kan vara extra gynnsam inledningsvis (Goodman, Wood \& Hendrickx, 2004).

Att få reda på vad som var rätt eller fel eller vad som skulle kunna bli bättre på en specifik uppgift kan vara effektivt för att prestera bättre. När återkoppling ges på process- och metakognitiv nivå har det visat sig kunna öka lärandet och på dessa nivåer behöver den också vara tydligt kopplad till en specifik uppgift (Hattie \& Timperley, 2007; Nicol \& Macfarlane-Dick, 2006). Mängden information är av betydelse när återkoppling ges på de olika nivåerna och att återkopplingen sker under arbetets gång är av vikt.

\section{Framåtsyftande}

En återkoppling innehållande information om vilka styrkor och utvecklingsbehov en elevs prestation uppvisat har visat sig vara effektivt för elevers lärande (Hattie \& Timperley, 2007, Kluger \& DeNisi, 1996). För att en elev ska finna strategier för hur hon ska kunna utvecklas vidare behövs även en framåtsyftande del, det vill säga hur prestationen kan bli bättre vid nästa tillfälle. Till exempel Nyquists studie (2003) visar att olika typer av återkoppling får olika effekt på lärandet. Hans forskningssammanställning, som baserats på 185 studier gällande högre utbildning, visar till exempel att återkoppling som endast förmedlar resultat $\mathrm{i}$ form av poäng eller betyg har den svagaste effekten. Återkoppling som däremot innefattar korrekta resultat, förklaringar och information om specifika aktiviteter för att förbättra resultaten har mycket god effekt för att stödja studenter i sitt lärande.

\section{Begriplig}

Elever behöver stöd för att förstå och för att kunna använda den återkoppling de får (Burke, 2007). Detta innebär att elever behöver lära 
sig strategier för kunna använda sig av återkoppling. I förlängningen innebär det att elever och lärare behöver ha samma känsla för kvalitet. Elever ska helst kunna veta sina egna utvecklingsbehov i förhållande till prestationer av högre kvalitet (Jönsson, 2010). För att eleverna ska kunna förstå vad olika begrepp betyder krävs både erfarenhet och variation (ibid). Ett sätt att få elever bekväma med att kommunicera mål och kriterier är att ge exempel på varierande kvalitet tillsammans med en återkoppling (Burke, 2007). Återkoppling som eleverna inte förstår kan komma att ses som icke användbar (Jönsson, 2012).

\section{Levererad $i$ rätt tid}

Det finns mycket forskning på när en återkoppling bör ges (se t.ex. Shute, 2008). Tiden för "leverans" är nära sammankopplad med uppgiftens form och svårighetsgrad. Därför finns det inga generella råd avseende tidpunkt för återkoppling, utan istället bör fokus riktas mot huruvida återkopplingen stöder lärandet. Det är i första hand kvaliteten på återkopplingen som är av vikt, det vill säga att den svarar på de tre frågorna: "Vad är målet?", "Var befinner sig elevens prestation i förhållande till målet?" samt "Hur ska eleven förbättra prestationen i riktning mot målet?" (Hattie \& Timperley, 2007).

\section{Individuellt anpassad}

Shute (2008) visar också på vikten av individuellt anpassad återkoppling och hon lyfter forskning som visar att återkoppling bör skilja sig åt beroende på om eleverna är hög- eller lågpresterande. Lågpresterande elever behöver ofta stöd för att klara av uppgiften i form av återgivande av korrekt svar och för att bygga upp självförtroendet medan hög-presterande elever ofta blir hjälpta av små hintar.

\section{Icke-värderande}

Värderande återkoppling i form av betyg eller beröm tenderar att inte ge någon positiv effekt på elevers lärande, utan kan till och med ge negativa effekter på lärandet (Black \& Wiliam, 1998; Hattie \& Timperley, 2007; Shute, 2008). Denna form av återkoppling är väldigt informationslös eftersom alla nyanser i form av elevens styrkor och utvecklingsbehov i relation till specifika mål eller uppgifter försvinner när den nyanserade informationen komprimeras till en betygsbeteckning (eller motsvarande, Jönsson, 2010). Även en kombination av 
betyg och framåtsyftande återkoppling tenderar att ta uppmärksamheten ifrån det som behöver revideras.

I en studie av Butler (1988) undersöktes olika typer av återkoppling bland 132 elever i år 7 (11-12 år) i fyra olika israeliska skolor. Urvalet bestod av både högpresterande och lågpresterande individer. Vid första lektionstillfället fick eleverna en uppgift som samlades in efter att de genomfört den. Eleverna fick sedan återkoppling på uppgiften $\mathrm{i}$ form av betyg, enbart kommentarer eller en kombination av betyg och kommentarer. Sedan fick eleverna en ny uppgift liknande den första samt fick veta att de skulle få samma sorts återkoppling som de fick efter den första lektionens arbete. Undersökningen visade att de svagare eleverna nådde samma resultat vad gällde lösningen av den andra uppgiften (denna var svårare), oberoende av vilken återkoppling de fick. Skillnaderna var dock stora för de högpresterande eleverna. De elever som enbart fick kommentarer presterade högre på nästa uppgift än de som enbart fått betyg. Däremot ledde kombinationen betyg och kommentar till sämst resultat. Enligt Butler berodde detta på att betyget tar uppmärksamhet ifrån kommentaren.

Kluger och DeNisi (1996) genomförde en metaanalys inkluderande 131 studier gjorda på återkopplingsinterventioner med olika typer av återkoppling och de fann att prestationerna i genomsnitt ökade, men över en tredjedel av återkopplingarna till och med försämrade elevernas prestation. De flesta av dessa interventioner var inte klassrumsbaserade och därmed inte autentiska. I deras "Feedback Intervention Theory" försöker Kluger och DeNisi att förklara detta fenomen. De föreslår att återkopplingsinterventionernas effekt minskar då återkopplingen fokuserar på eleven som person istället för på uppgiften. Desssutom anser de att icke specifik återkoppling kan leda till att eleverna ser den som meningslös. Återkoppling som däremot är för specifik kan orsaka problem vid bearbetning av informationen eller återigen rikta uppmärksamheten från uppgiften som till exempel att fokusera på mer kortsiktiga mål (Hattie \& Timperley, 2007).

\section{Formativ återkoppling i matematik}

En matematiklärare måste vara medveten om elevens matematiska kunskap och måste även kunna utvärdera och analysera elevernas 
konstruktioner av matematisk kunskap (Steinbring, 1998). Med elevers konstruktioner menas deras tolkningar av matematisk kunskap genom att reflektera och generalisera sina lösningar (Engström, 2004). Läraren måste även kunna jämföra dessa konstruktioner med vad som var avsikten med lärandet både för att hjälpa eleven vidare i sitt lärande samt för att kunna utveckla nya lärandesituationer. Matematisk kunskap är inte "färdig" utan dessa begreppsrelationer konstrueras aktivt av eleven i undervisningens sociala processer (Engström, 2004). Genom formativ bedömning, som återkoppling är en del av, kombineras elevens lärandeprocess och den interaktiva undervisningsprocessen mellan lärare och elev. Även om läraren inte direkt kan styra elevens lärandeprocess, kan hon eller han erbjuda en god lärandemiljö för eleverna. Därför är det viktigt hur en återkopplingspraktik ser ut.

\section{De olika dimensionerna är applicerbara på formativ återkoppling i matematik}

Formativ återkoppling i matematik kan beskrivas med samma dimensioner som för formativ återkoppling generellt. En återkoppling i matematik bör kombinera behovet av svar på Hattie och Timperleys (2007) tre frågor med fokus på kognitiva och självreglerande processer (återkoppling på metakognitiv nivå), återkoppling på uppgiftsnivå och återkoppling på processnivå (Rakoczy, Harks, Klieme, Blum \& Hochweber, 2013). Nedan beskrivs hur man skulle kunna kombinera dimensionerna med de fyra nivåerna och koppla detta till formativ återkoppling i matematik. Beskrivningen görs utifrån dimensionsperspektivet snarare än nivå-perspektivet eftersom alla dimensioner inte går att kopplas till en av de fyra nivåerna. Beskrivningen gör inte anspråk på att vara heltäckande, utan det kan finnas andra dimensioner som kan vara viktiga att ta hänsyn till.

\section{Specifik, men inte för specifik och kopplad till en specifik uppgift}

En formativ återkoppling bör bestå av en del som innehåller information angående området (till exempel ett speciellt ämne inom matematiken; Butler \& Winne, 1995). Vidare behövs information om vilka av de matematiska strategier som behövs för att lösa en uppgift som har tillämpats korrekt av eleven (styrkor) och vilka som inte har det (svagheter). Denna information anger var eleven befinner sig i förhållande till målet och vart hon är på väg. Återkopplingen blir mer effek- 
tiv om den inte bara är av korrektiv karaktär och inte bara fokuserar på rutinprocedurer, det vill säga inte hänger samman med begreppens betydelse eller problemlösningsprocessen. Denna dimension motsvarar återkoppling på uppgiftsnivå, enligt Hattie och Timperleys (2007) definition.

På detta sätt fungerar återkopplingen korrigerande samtidigt som den har grundläggande motiverande funktioner såsom att ge incitament (synliggör resultatet; Rakoczy m.fl., 2013).

\section{Framåtsyftande}

En formativ återkoppling bör även bestå av en del som reglerar lärandeprocessen (till exempel när och hur en särskild strategi är lämplig). Dessutom behövs information om hur de matematiska lösningarna kan bli bättre, det vill säga hur eleven ska närma sig målet. Detta bidrar till att återkopplingen blir framåtsyftande. Bedömningshandlingar med inriktning på process möjliggör hantering och tillämpande av matematiska begrepp och metoder samt kritiskt reflekterande av matematiska tillämpningar (Björklund Boistrup, 2010, s. 205). Denna dimension motsvarar återkoppling på processnivå, enligt Hattie och Timperleys (2007) definition och underlättar slutförande av uppgifter (erbjuder förslag på hur svårigheter kan hanteras).

När man arbetar på uppgifts- och processnivå (Hattie \& Timperley, 2007) innebär det att kognitiva processer (i detta fall matematiska beräkningar) används. Genom att kombinera återkoppling på uppgiftsoch processnivå med återkoppling på metakognitiv nivå stärks elevens "self-efficacy" (skapar möjlighet att klara av saker) och bidrar till upplevelsen av att man kan klara av saker.

\section{Begriplig}

Förutom att ge elever stöd för att förstå och för att kunna använda sin återkoppling i matematik måste återkopplingen inom matematik ta hänsyn till att matematik är representerat med symboler. Enligt Sfard (2000) beror betydelsen av symboler på hur de används även om de representerar ord eller annat. Det är genom att gradvis ta till sig olika sätt att använda ord och symboler som eleven kommer att förstå vad de betyder. Att ge återkoppling baserad på elevens prestation ger möjlighet till att utveckla olika begrepps betydelser och användning. Det 
ger även erfarenhet och ökar möjligheter till att närma sig prestationer av högre kvalitet genom att visa hur prestationen kan bli bättre. Kriterierna för högre kvalitet behöver omvandlas till något som eleven kan förstå, till exempel i form av att peka på vad som är bra, men som kan bli ännu bättre. Eleven blir därigenom även medveten om det egna utvecklingsbehovet och återkopplingen kommer troligen då också att upplevas som användbar.

\section{Levererad $i$ rätt tid, individuellt anpassad och icke-värderande}

Avseende när återkopplingen bör ges, att den ska vara individuellt anpassad och att den ska vara icke-värderande gäller samma förutsättningar som för formativ återkoppling generellt. Möjligen skulle en icke-värderande återkoppling kunna vara viktigare i matematik eftersom det finns kopplingar mellan förståelse och elevers uppfattningar. Man har sett att elevens uppfattning om sig själv och sin egen förmåga kan ha koppling till bland annat problemlösning och läsförståelse i matematik. Detta har rimligtvis då även betydelse för hur elever använder sin återkoppling i matematik (se vidare Österholm, 2006).

Positiv återkoppling fokuserar på styrkor och negativ återkoppling fokuserar på svagheter (Hattie \& Timperley, 2007). Både positiv och negativ återkoppling kan alltså förbättra lärandet såvida innehållet av information är tillräckligt för att hjälpa eleven till att kännas vid vad som är rätt eller fel i sin prestation eller förståelse. Intressant är att Hattie och Timperley (2007) beskriver att när elever beslutat sig för att uppnå ett mål kommer de sannolikt att lära sig mer som en följd av positiv återkoppling. När elever däremot tvingas att göra uppgifter är de mer benägna att lära sig då de får negativ återkoppling. Dock varnar Hattie och Timperley (2007) för kortsiktiga effekter av negativ återkoppling och för risken av undvikande av uppgifter på grund av återkommande negativ återkoppling. Negativ återkoppling riskerar också medföra hot mot elevers självkänsla och självtillit.

\section{Vad vi vet om hur elever använder formativ återkoppling i mate- matik}

Forskning visar att elevers engagemang i matematik beror på vilken typ av återkoppling de får. Björklund Boistrup (2010) har genom att följa undervisningen i fem klasser under en vecka i årskurs 4 studerat 
lärares och elevers kommunikation angående bedömning i matematikundervisningen. De vanligaste sätten att arbeta med bedömning i klassrum beskriver Björklund Boistrup utifrån fyra diskurser (kommunikationsmönster för bedömning). De olika sätten att arbeta med bedömning innebär enligt Björklund Boistrup att eleverna ges olika sorters återkoppling som ger olika möjligheter till att aktivt delta $\mathrm{i}$ arbetet och därmed olika möjligheter till lärande. Ju mer en elev bjuds in till att vara med och påverka situationen desto större chans till ökat lärande eftersom eleven då uppvisar större engagemang. De diskurser som är inriktade på matematiska processer ger eleverna möjlighet till hög grad av lärande och aktivt deltagande. Det finns således ett samband mellan återkoppling som fokuserar på processer och självreglerat lärande.

I en studie av Rakoczy med flera (2013) är det tydligt att om eleverna vill lära sig, det vill säga om de är lärandeorienterade, så finner de formativ återkoppling användbar. Om eleverna däremot av olika anledningar inte intresserar sig för att lära sig så spelar det ingen roll vilken återkoppling de får, eftersom de ändå inte har en tanke på att använda den. I studien fick eleverna en processorienterad återkoppling (formativ) för att undersöka hur eleverna upplevde återkopplingen samt om den gav någon effekt på en kommande uppgift. I deras studie stärkte formativ återkoppling elevernas "self-efficacy" (föreställning om sin förmåga att klara av saker) och elevernas uppfattning om användbarhet, vilket i sin tur kopplades till ökat intresse. Ingen motsvarande koppling mellan "self-efficacy" och ökad prestation kunde observeras, däremot mellan elevernas uppfattning om användbarhet och ökad prestation.

Även om eleverna fick en återkoppling som var formativ kunde man alltså inte se några effekter på elevernas prestationer, såvida de inte uppfattade återkopplingen som användbar. Att återkopplingen inte gav några effekter på elevernas prestationer berodde troligen på att eleverna fick återkoppling på ett helt prov (10 uppgifter), vilket medförde att eleverna inte kunde relatera återkopplingen till enskilda uppgifter. Detta är något andra studier tyder på är nödvändigt för att elever ska kunna utnyttja sin återkoppling eftersom det annars blir för abstrakt (t.ex. Shute, 2008). Vad som framförallt gav effekt på elevernas intresse och prestationer, var om de ansåg att återkopplingen var an- 
vändbar. Man vet att generell och abstrakt återkoppling om lärande i största allmänhet inte ger samma effekt som återkoppling som går att använda i närtid (Shute, 2008). Och i Rakoczy med fleras studie ser man att olika elever kan tycka olika om vad som är användbar återkoppling.

Även Havnes, Smith, Dysthe och Ludvigsen (2012) har ägnat uppmärksamhet åt hur elever i tre yrkesämnen och tre teoretiska ämnen (varav matematik var ett) hanterade återkopplingar. Huvudsyftet med deras studie var att undersöka hur både lärare och elever upplevde återkopplingspraktiken i respektive ämne. I studien såg man att elevernas engagemang var avgörande för hur de kunde använda återkopplingen som gavs. Passiva elever som behövde mer stöd kunde inte tillgodogöra sig återkoppling. Lärarna uttryckte att de hade svårt för att ge effektiv återkoppling till elever som inte skrev eller lämnade in uppgifter. Både lärarna och eleverna visade mer elevengagemang vid bedömningar och återkoppling i yrkesämnena än i de teoretiska ämnena. Ett tydligt mönster var att det i matematiken skedde färre återkopplingar. Återkopplingen var dessutom kort och eleverna var inte engagerade $i$ att diskutera kriterier och kamratbedömningar skedde aldrig. Det fanns ett fokus på att undervisa eleverna i strategier för problemlösning och att förvissa sig om att eleverna hade förstått uppgifterna och eleverna var mer engagerade i att korrigera fel efter prov.

Vidare visade det sig att lärarna över lag tenderade att värdera kvaliteten på återkopplingen högre än vad eleverna gjorde och klandrade eleverna för att inte använda den återkoppling som gavs. Eleverna däremot klagade på att återkopplingen som de fick inte var användbar. Dessutom fanns det en motsägelse i elevernas och lärarnas upplevelser, lärarna ansåg att eleverna endast var intresserade av betyg och inte önskade någon informativ återkoppling. Eleverna ville istället få utförlig och konstruktiv återkoppling eftersom de ansåg det vara användbart för deras framtida lärande och detta tyder på ett ökat behov av bättre kommunikation gällande elevernas lärande (Havnes m.fl., 2012). Enligt samma forskare är det av vikt att utveckla något som de kallar "bedömning-för-lärande-kultur"; något som både lärare och elever bör vara bekanta med. I en sådan kultur finns ett fokus på hur återkoppling bäst kan användas för att ökat lärande ska ske och involverar både lärare och elever. En sådan bedömningskultur tar lång tid 
att utveckla och den involverar förutom lärare och elever även skolledningen (Wiliam, 2011). Samtidigt lyfts även vikten av att återkopplingspraktiken ska vara integrerad i undervisningen och inte ses som en separat aktivitet.

Sammantaget har man sett att elever använder återkoppling i matematik mindre aktivt jämfört med till exempel hur återkoppling används i praktiska ämnen. En viktig faktor för att eleverna ska använda sin återkoppling är upplevelsen av användbarhet, som man sett lett till ökad prestation i matematik. Dock verkar det fokuseras mest på korrigering och strategier för problemlösning och/eller återkoppling som är för generell och abstrakt, vilket bland annat medför att eleverna känner att återkopplingen inte är användbar. Vidare har man sett att det $\mathrm{i}$ matematikklassrum sker färre återkopplingar och dessa är dessutom korta och eleverna är inte engagerade $i$ att diskutera kriterier.

Elevernas engagemang kan alltså vara avgörande för hur en återkoppling används. Därför är det viktigt att de aktivt bjuds in i arbetet i matematikklassrummet. Då återkoppling fokuserar på matematiska processer bjuds eleverna in till att delta aktivt, vilket i sin tur hör nära samman med självreglerat lärande.

I följande avsnitt görs en presentation av självreglering, vad det innebär och vad som har betydelse för självreglerat lärande.

\section{Självreglering}

Självreglerat lärande definieras enligt Winne (1996) som ett metakognitivt styrt beteende där eleven anpassar sina strategier i uppgifter de ställs inför. En nyckelstrategi inom formativ bedömning är att aktivera eleven till att "äga sin egen lärprocess" (Black \& Wiliam, 2009), vilket innebär att få eleven till att ta ansvar för och styra det egna lärandet. Elever som lär sig mer effektivt återkopplar till sig själva och har kognitiva strategier för att lära, komma ihåg och förstå i samband med att de genomför uppgifter i skolan (Hattie \& Timperley, 2007; Nicol \& Macfarlane-Dick, 2006). Dessutom tolkar de extern återkoppling från lärare eller andra elever i förhållande till deras interna mål (Nicol \& Macfarlane-Dick, 2006). De som är mindre effektiva är oftast 
mindre självreglerande och är mer beroende av externa faktorer såsom lärare eller matematikuppgifter för att skapa återkoppling (Butler \& Winne, 1995). Vidare söker eller införlivar de sällan återkoppling så att den förbättrar deras självreglerande strategier och därmed deras framtida lärande (Hattie \& Timperley, 2007).

Självreglering handlar således om hur elever styr och reglerar sitt agerande mot lärandemål (fokus på att lära sig) och innefattar autonomi, engagemang, självkontroll, självförtroende, självständighet och självdisciplin. Återkoppling har även en viktig funktion när det gäller att stärka elevens förmåga till självreglering (Butler \& Winne 1995; Hattie \& Timperley 2007; Black \& Wiliam 1998; Nicol \& MacfarlaneDick 2006).

Om man får tro Corno (2001) har många elever dessa självreglerande färdigheter, men utan att de alltid används. Problemet kan vara brist på motivation eller kraft att vilja. Enligt Wiliam (2010) har tidigare forskning efterlyst en breddning av detta forskningsfält för att bättre få en förståelse av elevers självreglering. I föreliggande studie kopplas självreglering ihop med elevers användande av en formativ återkoppling - en elev som använder en återkoppling är i viss mån självreglerande eftersom hon genom återkopplingen styr sitt eget lärande.

\section{Hur olika perspektiv är integrerade med varandra}

Avseende självreglerat lärande är det enligt Boekaerts (2006) svårt att skilja mellan kognitiva aspekter och motivationsaspekter, eftersom självreglerat lärande både är metakognitivt reglerat (övervakning, styrning och korrigering av egna lärandet) och affektivt laddat (kopplat till känslor). I Boekaerts "dual processing model" (1993) integreras kognitiva aspekter (t.ex. self-efficacy och målorientering), och motivationsaspekter (t.ex. intresse) och modellen kan appliceras när det handlar om elevers självreglering. Modellen bistår med att integrera en mängd olika aspekter genom att inkludera relationer mellan motivation och intresse, hur elever ser på sina framgångar och misslyckanden samt hur de utvecklar tankar om sin "self-efficacy" (Wiliam, 2010). 
I en undersökning gjord av Boekaerts (2001) fann man att hur mycket eleverna ansträngde sig för att klara uppgifterna primärt berodde på deras värdering av uppgiften, det vill säga uppgiftens värde i förhållande till arbetsinsats. Om uppgiften upplevs som värd att investera $i$ antar eleven vägen som Boekaerts (1993) benämner "growth pathway", där målet är att öka kompetensen och få eleven intresserad av uppgiften. Vidare benämns denna självreglering "top-down" eftersom drivkraften styrs av eleven. I denna process leder elevens "selfefficacy" till kognitivt anpassningsbara och metakognitiva strategier (strategier kopplade till lärande, att komma ihåg, att förstå samt övervakning och styrning av det egna lärandet; Bandura, 1977) och associeras med motivation med värde kommande inifrån eleven själv (Deci \& Ryan, 1994). En syn på sin förmåga som utvecklingsbar hjälper eleven att stanna på denna väg (Dweck, 2000). Vidare följer elever med lärandemål (dvs. fokus är att lära sig) sannolikt denna väg (Dweck \& Leggett, 1986). Då uppgiften inte upplevs lika värd att investera i styrs istället handlingen mot vägen "well-being pathway", där målet är att undvika "hot, skada eller förlust" (Wiliam, 2010, s. 35). Denna självreglering benämns "bottom-up". På denna väg leder sannolikt elevens "self-efficacy" istället eleven bort från en prestationsorientering (dvs. fokus är på betyg, beröm från läraren eller för att ge intryck av kompetens) där hon strävar efter att undvika något negativt och mot en prestationsorientering där hon strävar efter att uppnå något positivt (Bandura, 1977). Aktiviteter i samband med denna väg associeras med motivation vars värden relaterar till faktorer utanför individen (Deci \& Ryan, 1994) och eleven har ofta en syn på sin förmåga som oföränderlig (Dweck, 2000). Vidare är elever som antar denna väg oftast prestationsorienterade (Dweck \& Leggett, 1986) och de aktiveras alltså av yttre faktorer i lärandemiljön som till exempel betyg eller press från omgivningen, istället för av lärandemål. Vägen "Well-being pathway" leder ofta till sämre lärande (Wiliam, 2010), men kan dock ibland vara positivt för lärande eftersom eleven temporärt kan finna drivkraft och ledas in på vägen "growth-pathway".

Sammanfattningsvis kan elever anta endera av två olika vägar, beroende på vad som motiverar dem, då de tar sig an uppgifter. De kan befinna sig på olika nivåer på respektive väg och dessutom växla mellan vägarna (se vidare Boekaerts, 1993). 


\section{Har kontexten betydelse för självreglerat lärande?}

Ibland har självreglering beskrivits vara oberoende av kontextuella påverkansfaktorer (Pintrich \& Wolters, 1998). Självreglerande elever förväntas vara medvetna och ha förmågan att kontrollera sitt agerande för att nå uppsatta mål och en viktig aspekt av denna medvetenhet och kontroll är förmågan att kunna hantera och övervinna kontextuella hinder (Corno, 1989) och att därmed ha motivation och kognitiva resurser som krävs för att nå det uppsatta inlärningsmålet.

Zimmerman (2002) anser dock att den klassrumskontext eleverna befinner sig i spelar en viktig roll för främjandet av självreglerat lärande. Klassrum som inte ger utrymme för inflytande $\mathrm{i}$ form av till exempel tid eller val och utförande av uppgifter begränsar elevers utveckling av självreglerande strategier. Klassrumsforskning visar att skillnader i lärarnas undervisningsmetoder, bland annat den typ av arbete och uppgifter de ber eleverna att engagera sig i, kan påverka elevers motivation och de mål de sätter för sitt lärande och deras lärande till att bli självreglerande (Ames, 1992). Det verkar som att lärare inom matematik, naturvetenskap, samhällsvetenskap och språk har olika syn beroende på vilket ämne de undervisar i och att deras syn kan relateras till olika föreställningar om ämnets undervisning och praktik. Pintrich och Wolters forskning (1998) visar på att många matematiklärare uppfattade sitt ämne som definierat, sekventiellt och statiskt. Detta tyder på att matematikklassrum i vissa avseenden är annorlunda än andra klassrum (se vidare Grossman \& Stodolsky, 1994, 1995; Stodolsky \& Grossman, 1995; Stodolsky, 1988; Eccles, 1983, 1984; Wigfield, 1994; Wigfield \& Eccles, 1992, 1994) och att det finns en risk att dessa klassrum inte främjar självreglerande elever (Pintrich \& Wolters, 1998). Även den forskning som Havnes med flera (2012) bedrivit i sex skolämnen (varav matematik ett) visar på att matematik skiljer sig från andra ämnen genom att det finns ett stort fokus på korrekt svar och hur man kommer fram till det korrekta svaret (se även $\mathrm{Vad}$ vet vi om elevers användande av formativ återkoppling $i$ matematik). Vidare visar Havnes med fleras forskning att återkopplingspraktiken till viss del är mer relaterad till respektive ämne än till skolor som helhet och att undervisningskontexten och ämnets natur påverkar återkopplingspraktiken. 


\section{Hur situationen ser ut i matematikklassrum}

Om klassrumskontexten eleverna befinner sig i spelar en viktig roll för främjandet av självreglerat lärande är det intressant att veta hur situationen i svenska matematikklassrum ser ut. Därför följer en kort redogörelse för några utvärderingar/studier där matematikklassrum studerats.

Enligt Skolverkets undersökning från 2003 domineras matematikundervisningen på högstadiet och gymnasiet av en undervisningsmodell. Undersökningen är några år gammal, men senare utvärderingar/studier talar för att det på många håll ser likadant ut idag. Flertalet av lektionerna innehåller i huvudsak en gemensam genomgång av ett moment och därefter elevernas eget arbete. Vidare domineras undervisningen av diagnostiskt materiel, prov från läroböcker och traditionella poängsatta prov (där uppgifterna ofta är av rutinkaraktär liknande de som finns i läroböckerna). Dessutom tenderar läroböckerna att fokusera på procedurhantering och erbjuder ofta få andra kompetensaktiviteter eftersom elevers arbeten i hög utsträckning sker utifrån läroboksuppgifter (Skolverket, 2003). Även Skolinspektionens (2009) kvalitetsgranskning av 55 gymnasieskolor runt om i landet visar liknande resultat. Enligt denna granskning finns det en tradition i hur lärarna utformar undervisningen (Matematik A i detta fall).

Björklund Boistrup och Selander (2009) har identifierat två bedömningsdiskurser i matematikklassrum som de kallar "traditionell diskurs" respektive "aktivt deltagande diskurs". I fokus för den traditionella diskursen står elevernas korrekta svar på uppgifter och antal lösta uppgifter och det är främst skriftliga lösningar som bedöms. I fokus för den deltagande diskursen står problemlösningsprocesser och elevers kompetens då de arbetar tillsammans och detta tyder därmed på att matematikundervisningen ser annorlunda ut i vissa klassrum.

Även forskning av Bergqvist, Bergqvist, Boesen, Helenius, Lithner, Palm \& Palmberg (2009) och Björklund Boistrup (2010) visar att det $\mathrm{i}$ matematikklassrum är vanligt med ett fokus på procedurer med "litet matematikinnehåll” (dvs. fokus på uppgiften som sådan och ingen egentlig koppling till elevens fortsatta lärande i matematik). Här kan det till exempel handla om att bedöma ett svar på en uppgift som an- 
tingen rätt eller fel eller om strategierna eleverna använder är de rätta eller hur många uppgifter eleven löst. Det kan också handla om att $\mathrm{i}$ bedömningen fokusera på antalet rätta svar. Ofta är det så att eleven eller läraren jämför elevens svar på uppgifter med svar enligt facit som sedan markeras vara antingen korrekt eller fel (Björklund Boistrup, 2010; Skolverket, 2003; Skolinspektionen, 2009). I Skolverkets undersökning är det uppenbart att den rådande och uttalade provkulturen inom skolmatematiken påverkar elevers syn på kunskap och lärande i mycket hög grad. Mekaniskt räknande verkar vara det som skolämnet matematik i huvuddelen består av. Det viktigaste för eleverna under matematiklektionerna tenderar till att bli att hinna långt och inte till att förstå och utveckla begrepp och resonemang. Målet för studierna är för flera elever att hinna med boken och detta är något som även många lärare anser (Skolverket, 2003; Skolinspektionen, 2009).

Enligt Skolverkets rapport (2003) har elever som är vana vid att arbeta processinriktat en större lust att lära. Att arbeta processinriktat innebär en utveckling av förmågan att beskriva och reflektera kring matematiska lösningsprocesser och ett arbete med lösningar av icke rutinmässig karaktär. Eleverna har trots frustration inför svåra matematikuppgifter inte gett upp, utan de har utgått ifrån att de visst kan lösa uppgifterna eller att det i alla fall är värt ett försök. Det finns alltså svenska matematikklassrum där bedömningar fokuserar på processerna, vilket ökar möjligheter för elever att lära sig matematik (Björklund Boistrup, 2010).

Sammanfattningsvis verkar det som att processinriktat arbete skapar mer självreglering bland elever och eftersom matematikundervisningen verkar domineras av fokus på procedurer främjas därmed inte elevernas självreglering.

\section{Kognitiva aspekter och motivationsaspekter är tydligast}

Det kan konstateras att de tydligaste aspekterna som påverkar självregleringen är kognitiva och motivations-aspekter. Både kognitiva och motivations-aspekter har lyfts i tidigare forskning (se Pintrich \& Schrauben, 1992) om elevers studieresultat och deras engagemang i klassrumsundervisning. Även om det finns många faktorer som påverkar 
elevers motivation har speciellt tre konsekvent kopplats till självreglerat lärande. Dessa är elevens oro, elevens föreställning om sin förmåga att klara av saker ("self-efficacy") och värdet av att klara av dessa uppgifter (Pintrich \& Schrauben, 1992). Avseende kontextens påverkan pekar tidigare forskning i olika riktningar.

\section{Målorientering i matematik}

För att förstå elevers agerande och därmed deras användande av en återkoppling behöver man känna till deras mål med skolmatematiken (Hannula, 2006b). Elevernas mål (lärandemål respektive prestationsmål, t.ex. Dweck, 1986) kan beskrivas i två dimensioner (avoidance respektive approach; Elliot \& Murayama, 2008) och dessa varierar från elev till elev.

\section{Lärandemål och prestationsmål}

Den ena dimensionen av målorientering består av elevens definition av kompetens och hur denna kompetens bör utvärderas. Detta kan göras i förhållande till tillgänglig kunskap inom det aktuella området, i förhållande till den egna kompetensen sedan tidigare eller i förhållande till kunskapen hos andra i omgivningen. De två huvudkategorierna lärandemål och prestationsmål, vilket är en vanlig uppdelning av många motivationsforskare (se Dweck, 1986; Elliot, 2005; Lemos, 1999; Linnenbrink \& Pintrich, 2000; Nicholls, 1984), innefattas i denna dimension. En elev med lärandemål har fokus på utveckling av den egna kompetensen, det vill säga att lära sig, och eleven utvärderar därför sin måluppfyllelse i förhållande till den kunskap hon vill lära sig. Hon försöker alltså att öka sin kompetens och förstå eller att klara något nytt. En elev med prestationsmål fokuserar på att "visa" sin kompetens och hon "jämför" sig gärna med andra (Waege, 2007). Denna elev försöker med andra ord få sin kompetens bekräftad eller önskar hon undvika negativa bedömningar av densamma (Dweck, 1986; Nicholls, 1984). Målorienteringarna går ut på att man utvecklar kompetens eller att man visar sin kompetens (Deci \& Ryan, 2000).

Dweck och Nicholls menar att man kan se ett samband mellan inre motivation (dvs. handling utförs eftersom den upplevs som intressant, rolig eller på annat sätt tillfredsställande) och lärandemål å ena sidan och yttre motivation (handling utförs för att nå ett annat mål, till ex- 
empel bra betyg eller annan form av belöning) och prestationsmål å andra sidan (Ryan \& Deci, 2000). Dock anser Deci och Ryan att det inte går att se samband mellan prestationsmål och yttre motivation. De menar att det finns olika former av yttre motivation beroende på grad av autonomi eller självbestämmande som målet skapar för eleven. Självbestämmelseteorin (se vidare Deci \& Ryan, 2000; Ryan \& Deci 2002) innebär att människor har medfödda behov som de strävar efter att tillfredsställa för att på bästa sätt kunna utvecklas och växa. Dessa behov är personlig autonomi, kompetens och social meningsfullhet (Deci \& Ryan, 2000).

Yttre motivation kan internaliseras i olika grad och ju större grad av internalisering, desto mer positiva är följderna av handlingen. En elev kan till exempel försöka uppnå ett prestationsmål genom en kontrollerad form av reglering (intentionen med handlingen kommer ifrån omgivningen) eller från en mer autonom reglering (intentionen med handlingen skapad utifrån eleven själv; Deci, 1975). Ett exempel kan vara en elev som mycket gärna vill in på en särskild universitetsutbildning med en hög intagningspoäng, vilket genom internalisering skapar en drivkraft till att studera för att nå detta prestationsmål. Utfallen för dessa handlingar blir inte desamma; att en elev är prestationsorienterad säger ingenting om målets eller handlingens kvalitet. Det räcker inte med att ta reda på elevens mål med undervisningen, utan man måste även veta varför eleven försöker nå det bestämda målet (Deci \& Ryan, 2000).

Lärandemål som målorientering tycks vara sammankopplat med hög kvalitet i lärandet vad gäller metakognition, ihärdighet och benägenhet att revidera befintlig kunskap då eleven får information som inte stämmer med dess tidigare uppfattning (Ames, 1992; Pintrich \& De Groot, 1990). Elever med lärandemål har en viss benägenhet att relatera resultatet av lärandet till inre och kontrollerbara faktorer, till exempel kunskapsnivå eller ansträngning, och de kopplar inte resultatet av lärandet till självvärdet (Kamins \& Dweck, 1999). Dessa elever exponerar gärna sin kunskap för att upptäcka och korrigera brister och anledningar till detta kan vara ovan nämnda benägenheter. Elever med prestationsmål tenderar tvärtemot att sammankoppla prestation med självvärde och har oftare problem med att exponera sina bristande kunskaper för andra. Hos vissa kan till och med ett misslyckande in- 
nebära en känsla av mindre värde som människa. Dessa elevers självkänsla kan skyddas genom att eleven skyller misslyckanden på yttre faktorer snarare än på sig själva (Covington, 2000).

\section{Elever har positiv eller negativ strävan}

Den andra dimensionen av målorientering är i huvudsak affektiv och består av huruvida eleven strävar efter att uppnå något positivt (approach) eller att undvika något negativt (avoidance). Förväntningarna på framtida prestationer är ofta låga hos elever med prestations- och undvikandemål, de vill inte visa sig dumma eller misslyckas (Elliot \& Harackiewicz, 1996). Däremot har elever med prestationsmål, men med fokus på att vara bättre än andra, ofta bra självförtroende och de är ofta framgångsrika i skolan. Dessa elever kopplar ofta framgångar till inre, okontrollerbara och stabila faktorer som medfödd intelligens eller talang och de arbetar ofta hårt och med goda resultat (Dweck, 2000). Dock tyder flera studier på en ytinlärning hos dessa elever som är kontraproduktivt eftersom effektivt lärande kräver kontinuerlig granskning och revidering (Marton \& Säljö, 1984).

\section{Formativ återkoppling kan få elever mer lärandeorienterade}

Elevers mål är inte personliga karaktärsdrag utan i högsta grad påverkbara och ett resultat av tidigare erfarenheter av lärandet (Stipek, Salmon, Givvin \& Kazemi, 1998). Undervisningssituationer där misstag eller otillräckliga lösningar behandlas som naturliga delar i lärandet (dessa är dessutom nödvändiga inslag i lärandet (Kloosterman \& Gorman, 1990) främjar lärandeorientering (Tytler, Osborne, Williams, Tytler \& Cripps Clarke, 2008; Stipek m.fl., 1998). Det går alltså att få elever mer lärandeorienterade. En lärandeorientering bland eleverna bidrar i sin tur till en vilja hos eleverna till att arbeta med utmanande uppgifter och till att våga ta risker (Resnick, Bill, Lesgold \& Leer, 1991; Stipek m.fl.,1998), vilket i sin tur kan skapa en känsla av kompetens (Stipek m.fl., 1998). Dessutom kan formativ återkoppling få elever mer lärandeorienterade (ibid).

A learning orientation is also fostered more by feedback that is substantive and that focuses on improvement and mastery than by grades based on relative performance (Stipek m.fl., 1998, s. 467). 
Faktorer som inverkar på användande av formativ återkoppling

Tidigare har faktorer som är viktiga för hur en återkoppling utformas presenterats. Nedan beskrivs faktorer som påverkar hur elever använder sin återkoppling.

För att förstå hur elevers lärande bäst kan stödjas räcker det inte med att uppmärksamma enstaka aspekter av de faktorer som påverkar elevers beteende, kognition och affektiva upplevelser under lärandet (t.ex. Hannula 2006a). I föreliggande studie presenteras ett antal faktorer som visat sig vara viktiga för elevers agerande på en formativ återkoppling. Elevers agerande hör nära ihop med huruvida eleverna är motiverade till att använda en återkoppling i matematik. Enligt Hannula (2006b), Wedege och Evans (2004) finns det inte inom matematikdidaktisk forskning mycket skrivet angående elevers motivation till att lära matematik. Allt fler forskningsstudier pekar på att affektiva faktorer spelar roll i elevernas inlärningsprocess (se vidare Op't Eynde, De Corte, \& Verschaffel, 2002). Men enligt Hannula (2006b) behövs det mer forskning på detta område.

I föreliggande studie kopplas elevers upplevelser av formativ återkoppling samman med teorier om målorientering, deras föreställningar om matematik och bedömning, didaktiskt kontrakt, sociomatematiska normer och teorier om självreglerat lärande som ett försök till att få fram ytterligare betydande faktorer.

\section{Utmaningar med återkoppling att överbrygga}

Även om det inte finns några enkla riktlinjer för att stödja elevers lärande kan man åtminstone till viss del veta möjliga orsaker till varför eleverna inte använder sin återkoppling och därmed vilka hinder som behöver överbryggas (Jönsson, 2012). I litteraturen kan man hitta många faktorer som kan påverka studenters användning av återkoppling (här avses litteratur från högre utbildning och som inte är ämnesspecifik, men rimligen kan kopplas till gymnasieelever i matematik). Resultaten är ibland motsägelsefulla och därför har det enligt Jönsson (2012) varit svårt att urskilja tydliga tendenser. Dock finns det en del gemensamma utmaningar, vilka har kunnat identifieras. Nedanstående 
avsnitt baseras främst på Jönssons (2012) forskningsöversikt om olika hinder för att studenter ska använda sin återkoppling:

1) Återkopplingen behöver vara användbar genom att erbjuda tillräckligt med information för eleverna att agera utifrån och inom en snar framtid. Att ge återkoppling efter att eleverna har avslutat en kurs eller ett särskilt avsnitt skapar också problem eftersom det gör det svårt för eleverna att använda den. Det är viktigt att återkopplingen relaterar till kommande uppgifter och med hänsyn till dessa uppgifter gällande vilken nivå den bör ges på (uppgifts- eller processnivå). Elever uppskattar nämligen återkoppling på uppgiftsnivå då de ska lämna in sitt arbete igen, men för framtida uppgifter föredras återkoppling på processnivå.

2) Elever föredrar specifik, detaljerad och individuell återkoppling. Flera elever föredrar mycket återkoppling, men längden säger ingenting om användande, även om längre kommentarer kan ha positiv inverkan på ändringar (Ferris, 1997). Mer viktig återkoppling kan då dock överskuggas av mindre viktig (Shute, 2008). Vidare finns det en konflikt mellan det som eleverna önskar och det som gynnar dem i deras lärande. Till exempel önskar elever gärna få en positiv återkoppling i form av positiva kommentarer (Lipnevich \& Smith, 2009), speciellt elever med låg självkänsla (t.ex. Pitts, 2005) och detta har visat sig leda till färre ändringar (Ferris, 1997). Gradering eller poängsättning är ytterligare en sak där det finns en konflikt mellan vad eleverna vill ha och deras användning eftersom betyg riskerar att ta uppmärksamheten ifrån det som behöver revideras.

3) Auktoritär återkoppling är oftast inte produktiv. Läraren måste inta rollen som en samtalspartner, istället för att vara en auktoritär i klassrummet. Exempel på auktoritär återkoppling är att använda imperativ, ha en icke mjuk framtoning och att i huvudsak ge värderande kommenterar.

4) Eventuellt saknar elever strategier för produktiv användning av återkoppling. Istället tar de till tillfälliga och diffusa strate- 
gier som att arbeta hårdare eller göra "mentala anteckningar". Vidare använder de återkoppling som en indikator på framsteg eller för att motivera sig själva. Alternativt använder de den inte alls. Vissa studenter vänder sig dock till sin lärare för att få ytterligare hjälp, men det är viktigt att elever lärs hur man använder återkoppling (Burke, 2007).

5) Ett annat problem kan vara att elever inte förstår den återkoppling som de får. Eventuellt saknar elever förståelse av akademisk terminologi eller jargong. Enligt forskning så är ett sätt för elever att bli bekväma med den akademiska diskursen att få exempel tillsammans med återkopplingen (Burke, 2007) och att engagera elever med aktiviteter som tydliggör mål och kriterier.

Även om dessa utmaningar överbryggas är det inte säkert att återkopplingen leder till användande. Utöver detta finns ytterligare utmaningar.

\section{Motivation}

Motivation är ett komplext fenomen, men en grundläggande förutsättning för lärande och goda prestationer (Hannula, 2006). På grund av dess komplexitet har det utvecklats flera olika teorier om motivation och dessa har använts för att förklara dess olika aspekter.

Sedan tidigare vet vi att elever inte alltid använder den återkoppling som de får (Jönsson, 2012) och enligt Wigfield och Eccles (2002) borde det höra samman med bristande motivation. Motivation handlar alltså om en påverkan till att göra någonting, som orsakar faktisk handling och gör så att eleven riktar och fortsätter sitt agerande, det vill säga att göra vissa saker och undvika andra (Hannula, 2006; Waege, 2007). I detta fall handlar det om att rikta sitt agerande mot en formativ återkoppling i matematik.

Tidiga forskare inom motivationsforskningen betraktade motivation som en inre drivkraft (Graham \& Weiner, 1996). Sedan har motivation mer betraktats som en produkt av elevens förväntningar om att lyckas med en uppgift och det upplevda värdet av att genomföra 
denna uppgift, det vill säga mer betraktats som ett resultat av kognitiva beslut. Till exempel "attribution theory", "self-worth theory" (se vidare Graham \& Weiner, 1996), "self-efficacy theory" (Bandura, 1994, 1997) och "goal-orientation theory" (Ames, 1992; Elliot \& Dweck, 1988; Graham \& Weiner, 1996) förutsätter att individer bara anstränger sig när de upplever att arbetet de utför kommer att resultera $i$ att deras personliga mål uppfylls. Enligt Kloosterman (2002) finns det ett behov av bättre förståelse av elevers motivation i matematik och det är viktigt att arbeta utifrån flera olika perspektiv. Här följer några olika perspektiv/dimensioner av betydelse för elevers motivation.

\section{Inre och yttre motivation att lära sig matematik}

Motivation kan delas in i olika typer beroende på varför handlingen utförs eller på de mål man har med handlingen. Som tidigare nämnts skiljer man ibland på inre och yttre motivation (t.ex. Deci \& Ryan, 2000). Exempel på detta kan man se i Goodchilds forskning (2001) där en elev anses vara yttre motiverad när hon arbetar med en aktivitet för att uppnå något som egentligen inte har med aktiviteten att göra, som till exempel erkännande. Vidare anses en elev vara inre motiverad då hon utför en handling på grund av värdet i sig självt och eleven är engagerad i uppgiften för att lära sig och förstå. Detta ligger i linje med till exempel Deci och Ryans definition.

Yttre motivation kan sedan delas in i olika underkategorier beroende på hur autonomt reglerade individens handlingar är (se vidare "selfdetermination theory" (Deci \& Ryan, 1985; Deci \& Ryan, 2000)). Många studier visar på att olika typer av motivation kan kopplas till skillnader i intresse, ansträngning, känslor samt prestationer (Deci \& Ryan, 2000). Inre motivation har hög grad av autonomi (agerande utifrån eget intresse och värderingar) och leder till större intresse, större ansträngning, mer positiva känslor och bättre prestationer. Hög grad av autonomi innebär alltså en känsla av att själv äga och styra över sina uppgifter och se meningen med dem (ibid). Då skolsituationer upplevs som intressanta och väcker elevens nyfikenhet stöds elevers upplevelser av autonomi och kompetens och detta kan i sin tur främja den inre motivationen (Grouws \& Lembke, 1996; Hannula, 2006). Även upplevelse av samhörighet är viktig för elever (Bergqvist mfl., 2009). Detta innebär att eleven känner sig trygg tillsammans 
med lärare och de andra eleverna och innebär att hon vågar ställa frågor och diskutera och därmed att riskera visa sina svagheter (Resnick mfl., 1991; Stipek mfl., 1998).

Vidare kan inre och yttre motivation för att lära matematik diskuteras i relation till begreppen I- och S-rationaliteter (Mellin-Olsen 1984, 1987). Enligt Mellin-Olsen måste en elev finna anledning att lära sig matematik, det måste finnas en rationalitet för lärandet. Denna är sammansatt av två komponenter: instrumentell (I-rationalitet) och social (S-rationalitet). Den instrumentella rationaliteten fungerar som ett instrument för eleverna; eleverna vet att de har nytta av matematik och ett betyg däri i framtiden och de behöver kunskap, eller åtminstone betyg, i matematik för bland annat fortsatta studier.

In its purest form the I-rationale will tell the pupil that he has to learn, because it will pay out in terms of marks, exams, certificates and so forth (Mellin-Olsen, 1987, s. 157).

Den sociala rationaliteten är knuten till ämnesinnehållet i sig; matematiken upplevs som rolig och intressant.

This knowledge has a value besides its importance for the external examination (Mellin-Olsen, 1987, s. 157).

Hur ett lärande kommer äga rum är beroende av elevernas värdering av inlärningssituationen. Då en handling utförs på grund av en yttre motivation $\mathrm{i}$ form av belöningar som betyg till exempel eller för att skuld och skam vill undvikas, eller för att uppnå en känsla av stolthet har den likheter med I-rationalitet. Bägge formerna av anpassning har en yttre placering av kausalitet (Waege, 2007). Om däremot en elevs handling utförs utifrån inre motivation, att hon tycker uppgiften upplevs som intressant har den likheter med S-rationalitet.

\section{Affektiva upplevelser och dess koppling till agerande och inlärning}

Elevers förväntningar på att kunna lyckas med en aktivitet eller deras självförtroende att klara av den samt värdet av denna aktivitet påverkar elevers motivation (se vidare "expectancy-value theory", t.ex. Wigfield \& Eccles, 2000). Dock har eleven kvar affektiva minnen från tidigare liknande aktiviteter, tolkningar av orsakerna till resultaten av dessa aktiviteter, egna målsättningar med lärandet, bedömningar samt 
attityder som påverkar elevens förväntningar. Även den egna kompetensen i relation till uppgiftens krav och attityder samt beteenden hos personer som av eleven anses vara viktiga i sin omgivning påverkar elevens förväntningar. En elev som ställs inför något som hon tycker är intressant och något som hon tror kan vara till hjälp för hennes lärande och som hon dessutom tror hon kommer klara av kommer troligen att gå in i denna lärandesituation med hög motivation. Men en elev som tvärtemot inte tror att hon klarar av uppgiften, inte tycker den är intressant och/eller inte tror den är lärorik kommer troligen att ha en lägre motivation till att anstränga sig för att lösa uppgiften (Bergqvist m.fl. 2009).

Banduras "self-efficacy-teori" (1994, 1997) handlar om människans upplevelse av sin förmåga att klara av saker. Det mest effektiva sättet att stärka tron på att man ska klara av något är att man lyckas med det man valt att göra. Detta har betydelse för elevers motivation och kan vara av betydelse för de mål en elev sätter upp och för den insats och uthållighet eleven tycker det är värt att satsa när uppgifterna blir för svåra.

Enligt Ryan och Deci (2000) hör motivation även ihop med olika typer av affektiva upplevelser. För att elever ska sätta igång en handling, i detta fall använda den återkoppling som de får med intention att utveckla deras prestationer och sedan fortsätta med denna aktivitet, krävs alltså att eleven är motiverad till detta. Elever med högre motivation har större drivkraft till att sätta igång handlingar som troligen leder till lärande och till att fortsätta med denna aktivitet även när det är "jobbigt" eller svårt. Elever utan motivation för ett visst lärande saknar istället drivkraft till att påbörja och fullfölja beteende mot aktiviteter som leder till uppfyllande av lärandemålen. Det finns samband mellan elevers motivation, deras lärande och prestationer (Schunk, Pintrich, \& Meece, 2008).

Undervisningens påverkan på elevers motivation att lära sig matematik

Typen av motivation, det vill säga inre eller yttre, har betydelse för elevers prestationer, beteende och känslor (Ryan \& Deci, 2000). Då elevers motivation har undersökts genom observation av ett lektionstillfälle har man sett att deras motivationstyp (inre eller yttre motivat- 
ion), lärandeorientering, deras kunskapssyn, graden av autonomistöd, lärarens förväntningar och krav på eleverna och uppgiftens värde har stor betydelse för att förklara koncentration och ansträngning (Bergqvist m.fl., 2009). Vissa faktorer är egenskaper hos eleverna själva, men dessa egenskaper har vuxit fram i samspel med omgivningen, till exempel skolan och matematikklassrummet. Dessutom är dessa egenskaper påverkbara. Det är viktigt att skapa undervisningssituationer som inte påverkar elevers självkänsla, som inte driver fram jämförelser elever emellan, där kunskapsbrister kan vara viktiga steg i lärandet och där syftet med lärandet inte är prestationen i sig utan istället kunskapsutvecklingen (ibid).

Enligt Cobb, Wood, Yackel och Perlwitz (1992) kan lärarens sätt att undervisa i hög grad påverka elevernas syn på matematik och elevernas utveckling av förståelse i matematik. Deras forskning visar också att de elever som är vana vid undersökningsbaserat arbetssätt (s.k. inquiry-based) i mindre utsträckning utvecklar prestationsmål än elever med mer traditionell undervisning.

Även Grouws och Lembke (1996) diskuterar hur matematikläraren och klassrumskulturen kan påverka elevers motivation till att lära matematik (inre motivation). Deras utgångspunkt handlar om att skolmatematik mer handlar om att tillägna sig matematiska begrepp och färdigheter. I matematikklassrummet får elever signaler om vad det innebär att kunna matematik och vad detta lärande har för social betydelse. I alla klassrum finns det en egen kultur som är baserad på den rådande interaktionen mellan elevernas syn och lärarens handlingar. Och för att eleverna ska vilja lära sig matematik är det viktigaste att matematikundervisningen överensstämmer mellan lärarens organisation av undervisningen och den gällande klassrumskulturen, annars kan det uppstå frustration hos både lärare och elever och därmed en påverkan på elevernas lärande i matematik (ibid). 


\section{Föreställningar som har betydelse för elevers motivation att lära matematik}

Enligt Kloosterman är motivation en kognitiv aktivitet och eleverna antas göra specifika val om hur och när de anstränger sig för att lära (Kloosterman, 1996; Stipek, 1996). Valen är baserade på elevernas föreställningar, det vill säga deras personliga uppfattningar, vilka medierar handling. En elevs föreställning är alltså något som en elev vet eller känner och som påverkar deras insats till att lära sig matematik (Kloosterman, 1996) eller som här till att använda den återkoppling som de får.

Elevers föreställningar om matematik ("beliefs") och matematiklärande kan ha en väsentlig påverkan på deras intresse för matematik, deras glädje av matematik och deras motivation till att lära matematik. Det finns ingen entydig definition på "beliefs" och här används Op't Eynde med fleras något breda definition:

Students' mathematics-related beliefs are the implicitly or explicitly held subjective conceptions students hold to be true, that influence their mathematical learning and problem solving (Op't Eynde m.fl., 2002, s. 17).

Vidare delar dessa författare in elevers föreställningar i matematik i tre kategorier: 1) föreställningar om matematikutbildning, 2) föreställningar om självet, och 3) föreställningar om den sociala kontexten. Föreställningar om självet är i sin tur indelad i fyra underkategorier; föreställningar om målorientering, föreställningar om uppgifternas värde, föreställningar om kontroll och föreställningar om förväntning på att klara av uppgifterna. Även Kloosterman (1996) presenterar en modell av två föreställningar som han menar har betydelse för elevers lärande i matematik: 1) föreställningar om matematik och 2) föreställningar om att lära matematik. I den senare innefattas eleven själv som matematikelev, lärarens roll och andra föreställningar om matematiklärande. Enligt Kloosterman är elevens föreställningar om matematik avgörande för vilken form av matematik hon kommer att lära sig (regler och formler utantill eller utveckla begreppsmässig förståelse och se sammanhang mellan olika områden i matematiken). Dessutom påverkar elevers föreställningar om matematiklärande deras motivation 
(Boaler, 1997; Cobb, 1985; Grouws \& Lembke, 1996; Kloosterman, 1996; Middleton \& Spanias, 1999). Elever har en föreställning om vad det innebär att lära sig matematik och de har en förväntning på vad både de själva och läraren ska göra för att de ska lära sig matematik. Skulle matematikundervisningen bryta mot dessa föreställningar kan deras motivation i hög grad påverkas. En förändring av undervisningen kan innebära en stor konflikt hos eleverna och därför är det viktigt att läraren förklarar varför hon gör som hon gör, det vill säga varför undervisningen ser ut som den gör (Kloosterman, 1996, 2002). I Boalers studie (1997) såg man att de elever som följde en traditionell matematikundervisning (läroboks- och uppgiftscentrerad undervisning) hade en föreställning om att matematik handlar om att minnas regler och formler. I litteraturen kopplas elevers föreställningar avseende motivation ofta samman med teorin om självreglerat lärande (se vidare Boekaerts, 1999; Pintrich, 1999; Butler \& Winne, 1995). En förändring av traditionell matematikundervisning, $i$ form av införande av formativ återkoppling, kan således skapa en konflikt.

Enligt både Grouws och Lembke (1996), Middleton och Spanias (1999) och, som nämnts, Kloosterman (1996) är elevers syn på matematik och matematiklärande och överensstämmelsen mellan denna syn och matematikundervisningen av stor betydelse för elevers motivation att lära matematik. Yates (2000) skiljer mellan optimistiska och pessimistiska förklaringsmodeller. En pessimistiskt orienterad elev tolkar att göra fel i matematik som en negativ händelse och det har vidare en negativ inverkan på dess målorientering i matematik. Men även Yates (2000) påpekar vikten av att göra fel i matematik och att det är oundvikligt samt att eleverna bör lära sig att betrakta sina fel på ett positivt och konstruktivt sätt.

\section{Den sociala dimensionen}

I en studie gjord av Mendick (2002) ser man att om en lärare fokuserar på slutresultat $\mathrm{i}$ form av betyg, blir detta fokus styrande för både undervisningen och elevernas och lärarens metodval samt vilka lösningar som godkänns i klassen. Under hennes matematiklektioner arbetade eleverna individuellt med uppgifter som fokuserade på att lära metoder och regler. Undervisningen innebar konkurrens mellan elever och mellan matematikklasser hon undervisade i. I detta klass- 
rum framställs inte glädje och förståelse som orsaker till att arbeta med matematik, utan eleverna måste hitta andra orsaker för att känna mening till att lära matematik som att göra bra i provsammanhang till exempel.

Även Eccles och Wigfield (2002) har ett liknande resonemang, att det är viktigt att förstå den kontext elever befinner sig i för att förstå deras motivation. Enligt dem är det även svårt för läraren att förändra en prestationskultur så länge tävling och betygsfokusering i samhället i stort premieras.

Den sociala dimensionen kan förklaras med hjälp av didaktiskt kontrakt och sociomatematiska normer, vilka förklaras djupare nedan.

\section{Didaktiskt kontrakt}

Matematikundervisningen i skolan bidrar till elevers föreställningar om vad matematik är, hur man lär sig matematik och varför man lär sig matematik (Wedege \& Skott, 2006). Detta sker bland annat genom något som man metaforiskt beskriver som kontrakt och som utvecklas via undervisningen. Kontraktet är tyst och dolt och det var den franska matematikdidaktikern Brousseau (1997) som introducerade begreppet. Det didaktiska kontraktet innefattar vilka regler som gäller för interaktionen i matematikklassrummet mellan läraren och den enskilde eleven samt mellan eleverna. I en undervisningssituation uppstår ett speciellt förhållande mellan lärare och elever i deras gemensamma möte med ämnet matematik och detta leder till ett antal regler för undervisning och lärande. Ett kontrakt kan till exempel vara en lektions uppbyggnad; Att läraren alltid inleder lektionen med att ha en kort genomgång på tavlan av det som eleverna behöver inför arbetet med dagens uppgifter och att sedan hela lektionen används till att räkna på uppgifterna varpå man slutligen har en summering på tavlan. Detta kan bidra till att eleverna i en sådan klass uppfattar matematik som något man ska lösa uppgifter med (se Blomhøj, 1995; Wedege \& Skott, 2006).

Olika typer av lärandemiljöer leder till olika typer av kontrakt (Wedege \& Skott, 2006). Ett didaktiskt kontrakt fungerar både som förutsättning och som villkor för matematikundervisningen i klassen. Detta leder till problem då eleverna har en förväntan på undervisningen och 
det inte blir som de har tänkt sig. Då behöver det didaktiska kontraktet omförhandlas (Brousseau, 1997). Kontraktet är implicit, vilket innebär att det blir synligt först när det bryts. Det didaktiska kontraktet inbegriper ömsesidiga förväntningar om att eleven lär sig och att läraren undervisar, det vill säga att läraren möjliggör lärande. Men det gäller att läraren möjliggör lärande på det sätt som eleven förväntar sig för att en omförhandling ska undvikas (ibid).

Sammanfattningsvis innefattar det didaktiska kontraktet hur lärare och elever förväntas agera. Det didaktiska kontraktet skapas med andra ord mellan personerna i klassrummet (t.ex. att läraren rättar och kommenterar proven och eleverna deltar i klassrumsdiskussioner).

\section{Sociomatematiska normer}

I ett matematikklassrum skapas sociala normer (de är generella och gäller för många olika aktiviteter, men är ämnesberoende), men även sociomatematiska normer, det vill säga det förhållningssätt till matematik som råder hos elever och lärare sinsemellan (Engvall, 2013). Om de sociala normerna, vilka utvecklas i samspel mellan lärare och elever, framhåller värdet av att eleverna kommer fram till rätt svar på uppgifter, så kommer detta att skapa ett matematikklassrum som väsentligt skiljer sig från ett klassrum där normen är att eleverna bör få diskutera olika lösningar till olika uppgifter eller problem. Skillnader i normsystem kan visa sig beroende på hur felaktiga svar från elever värderas. I vissa klassrum är det legitimt och till och med till fördel för utvecklingen av förmågorna att visa upp sina misstag (Stevenson \& Stigler, 1992). I vissa klassrum gäller det motsatta; att ett felaktigt svar ses som ett personligt nederlag och något lärarna vill hjälpa eleverna att undvika (Yackel, 2000).

Den rådande kulturen i matematikklassrummet bildar grund för de matematiska aktiviteterna i undervisningen som innefattas i de sociomatematiska normerna (se vidare Yackel \& Cobb, 1996). Dessa normer styr lärandet av exempelvis matematiska begrepp och metoder och kan vara normer för vad som utgör matematiskt acceptabel förklaring, en annorlunda lösning av ett problem eller en effektiv eller snygg lösning (Cobb \& Yackel, 1996; Yackel \& Cobb, 1996). De sociomatematiska normerna reglerar interaktionen mellan elever, lärare och ämnet. Även om det matematiska lärandet i klassrummet påverkas av 
dessa normer som redan är etablerade bland elever och lärare pågår en ständig process.

\begin{abstract}
With regard to sociomathematical norms, what becomes mathematically normative in a classroom is constrained by the current goals, beliefs, suppositions, and assumptions of the classroom participants. At the same time these goals and largely implicit understandings are themselves influenced by what is legitimized as acceptable mathematical activity (Yackel \& Cobb, 1996, s. 460).
\end{abstract}

Enligt Yackel och Cobb (1996) är de sociomatematiska normerna, elevernas mål och föreställningar om matematik och matematiklärande relaterade till varandra. Hur läraren interagerar med eleverna har stor betydelse för hur elever tolkar sin kunskap och sina förmågor. De sociomatematiska normerna, som utgör grund för den matematiska praktiken i klassrummet, skapas och förändras i denna interaktion och de är av stor betydelse för elevers lärande i matematik (Kazemi \& Stipek, 2001).

Yackel och Cobb (1996) lyfter fram en teoretisk modell för analys av undervisning och lärande i matematikklassrum. Den teoretiska modellen innefattar en samverkan mellan två perspektiv, det individuella/psykologiska och det sociala och den bygger på en kombination av att observera och analysera utvecklingen av de sociala och sociomatematiska normerna och att ur ett psykologiskt perspektiv observera den enskilde elevens aktivitet vid deltagande i klassrumsaktiviteter. Dessa två perspektiv är beroende av varandra. Varje social nivå har en motsvarande psykologisk nivå och dessa konstrueras och revideras parallellt. I föreliggande studie lyfts båda perspektiv, dels genom kontextens påverkan på eleven samt eleven själv genom målorientering, föreställningar och motivation.

Lärarens sätt att styra över själva mönstret för kommunikationen i klassrummet resulterar i att eleverna lär sig i vilken omfattning olika tillvägagångssätt är accepterade. Detta eftersom det som läraren gör är förväntat av eleverna i klassrummet (Pimm, 1987). För att andra typer av matematikklassrum ska utvecklas behövs ett medvetet arbete som uppmärksammar normer (Cobb, Wood \& Yackel, 1993). Även Sfard (2000) och Jablonka (2011a) poängterar vikten av att elever lär sig de dolda reglerna i klassrummet för att kunna utveckla nödvändiga fär- 
digheter som behövs för att kunna delta i matematikundervisningen med framgång.

The rules regulate both at the same time, the expected mathematical productions that a student has to display in order to be considered as successful, as well as the favoured behaviour, aspirations and attitudes (Jablonka, 2011a, s. 67).

Sammanfattningsvis är de sociomatematiska normerna de regler eller traditioner som gäller i klassrummet kopplat till matematik (t.ex. vad som utgör ett matematiskt bevis). Termen används för att kunna diskutera hur olika uppfattningar om matematik och olika matematiska beteenden etableras och regleras i samband med matematikundervisning.

\section{Slutsatser inför föreliggande studie}

Självreglerat lärande är ett metakognitivt styrt beteende där eleven anpassar sina strategier i uppgifter de ställs inför. Ett metakognitivt beteende innefattas av egenkontroll (övervakar sitt lärande), styrning (av det egna lärandet) och korrigering av åtgärder. Självreglerande elever lär sig mer effektivt i samband med att de genomför uppgifter i skolan genom att de återkopplar till sig själva och har kognitiva strategier för att lära, komma ihåg och förstå. De elever som använder sin återkoppling är således i vis mån självreglerande eftersom de genom återkopplingen styr sitt egna lärande. Därför har återkoppling en viktig funktion när det gäller att stärka elevens självreglerande förmåga. Med andra ord kopplas självreglering ihop med elevers användande av en formativ återkoppling i föreliggande studie. Dock kan det finnas en brist på motivation hos de elever som inte använder sin återkoppling och som därmed inte är självreglerande, eftersom motivation handlar om att göra vissa saker och undvika vissa saker. De riktar helt enkelt inte sitt agerande mot återkopplingen.

Det går alltså tydligt att se att olika aspekter är nära sammanbundna med varandra. Självreglerat lärande är nära sammanbundet med kognitiva aspekter och motivationsaspekter. I föreliggande litteraturgenomgång har kognitiva aspekter, så som till exempel målorientering, self-efficacy och självvärde, presenterats. Dock är motivation en produkt av kognitiva aspekter och dessa går inte att separera. Motivat- 
ionsaspekter är ett komplext fenomen med flera olika perspektiv och som här presenteras i form av till exempel föreställningar som har betydelse för elevers motivation till att lära matematik, vilket i sin tur är nära förknippat med didaktiskt kontrakt och sociomatematiska normer. Självreglering och andra aspekter kopplade till denna kan alltså påverkas av undervisningen som eleverna deltar i. Andra faktorer som kan inverka på elevers användande av formativ återkoppling, så som återkopplingens utformning, presenteras också. För att hjälpa elever till att använda en formativ återkoppling i matematik behöver flera olika aspekter beaktas.

I föreliggande studie undersöks om någon aspekt är mer framträdande än någon annan och varför eleverna använder respektive inte använder den återkoppling de får samt vad vi kan påverka för att eleverna ska använda den. 


\section{Metod och genomförande}

I följande avsnitt beskrivs forskningsdesignen och en förklaring ges till vilka moment som genomförts, hur de genomfördes och varför vald metod användes. Elevernas normala kontext beskrivs för att bättre kunna förstå deras uttalanden. Slutligen ges en förklaring till hur analysen genomförts och vilka etiska frågor som beaktats.

\section{Forskningsdesign}

För att kunna svara på forskningsfrågorna ((i) Hur upplever eleverna en formativ återkoppling?, (ii) Hur använder eleverna en formativ återkoppling? och (iii) Hur samverkar elevernas upplevelser, hur de använder återkopplingen och deras målorientering?) var det nödvändigt att skapa rätt förutsättningar. Det gjordes genom att undersöka vilka metoder som på bästa sätt kunde understödja det arbetet och genom att ta fram en strategi för genomförandet. För att kunna undersöka elevers upplevelse av formativ återkoppling krävdes således att det genomfördes en formativ bedömning. I dagens skolor så är det inte säkert att förutsättningen finns för att återkoppling ska fungera så som man skulle önska (Higgins m.fl., 2002). Därför fick eleverna i föreliggande studie en skriftlig formativ återkoppling som utformades enligt teorier om hur en formativ återkoppling bör se ut (se vidare i kapitlet teoretiska utgångspunkter och tidigare forskning). Genomförandet av studien skedde i ett antal steg som redovisas nedan. 


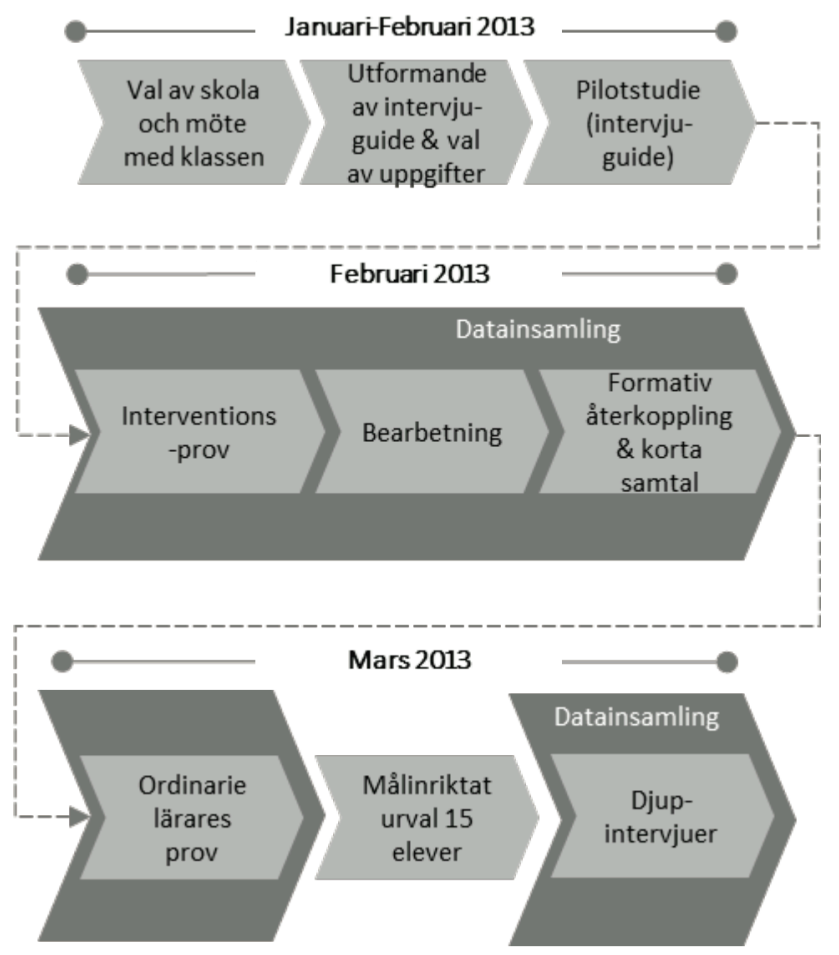

Figur 1. Tidslinje med genomförandesteg

\section{Val av skola och möte med klassen}

När forskningen presenterades för ett matematik-kollegium på en skola blev alla intresserade av att medverka. Enligt Burgess (1991) och Kvale (1997) är det oerhört viktigt att få tillgång till en grupp som är villig att dela med sig av sina erfarenheter $\mathrm{i}$ intervjusituationer och detta är en anledning till att denna skola valts. Valet att arbeta med en lärare gjordes utifrån vad som rymdes tidsmässigt inom studien.

Inför mötet med klassen var det svårt att veta hur mycket information som behövde ges till eleverna $i$ förväg. För att inte påverka deras tankar kring upplevelser av den formativa återkopplingen delgavs eleverna endast hur undersökningen skulle gå till och alltså inte någon bakgrund till studien. Däremot redovisades studiens syfte för dem, det vill säga vilka frågor det var som studien avsåg besvara. 


\section{Utformande av intervjuguide och val av uppgifter}

I arbetet med forskningsdesignen gjordes fältbesök som en utgångspunkt för utarbetande av intervjufrågor för att få en uppfattning om klassens normala återkopplingspraktik. För att på något sätt kunna förstå deras upplevelser av återkopplingen var det nödvändigt att även få en insyn i deras föreställningar om skolämnet matematik och detta gjordes i samband med intervjuerna. En intervjuguide som fokuserade på vissa teman och som innehöll förslag till frågor togs fram och därpå gjordes ett urval av provuppgifter.

Provuppgifterna var utvalda i samråd med ordinarie lärare för att passa dennes planering. Uppgifterna behandlade det centrala innehållet "samband och förändring" och för urvalet av uppgifter var det en balans mellan att eleverna skulle klara av att lösa uppgifterna och att de inte skulle vara för lätta. Detta var inte lätt eftersom en och samma uppgift kan vara olika svår för olika elever beroende på elevens förkunskaper, tidigare erfarenheter med mera (Mattson, 1989). Återkoppling kan ges i samband med olika moment beträffande matematikundervisning och lärande. Till exempel kan återkoppling ges till elever vid olika typer av projekt, konstruktion av uppgifter till lösningar från klasskamrater, teaterstycken, framställning av posters, videosekvenser med mera (Niss, 2007). På grund av elevernas vana vid att lösa uppgifter i sin lärobok på egen hand blev elevernas svar på två matematikuppgifter föremål för återkoppling eftersom situationen så mycket som möjligt skulle likna deras ordinarie undervisning.

\section{Test av intervjuguiden genom pilotstudie}

Innan undersökningens start (våren 2013) genomfördes en pilotstudie för att fastställa intervjufrågorna. Informanten var en elev på samhällsvetenskapliga programmet årskurs ett. Genom pilotstudien testades intervjufrågorna, om det framkom vad som avsågs och om frågorna gav de svar som behövdes för föreliggande studie. Eftersom halvstrukturerade intervjuer genomfördes påverkade detta inte frågeformuläret i så hög grad utan detta sätt gav möjligheter till att formulera om frågan då missförstånd upptäcktes. Pilotstudien gav därför inte upphov till några särskilda ändringar. 


\section{Interventionsprov}

Inledningsvis fick alla elever i klassen två provuppgifter av typen problemlösning där eleven inte har någon färdig lösningsmetod tillgänglig och där hon får använda redan erhållna kunskaper i nya och okända situationer (icke rutinmässig). Uppgifterna har valts från tidigare Nationella prov i matematik kurs A.

För att få tillräckligt stor urvalgrupp efter eventuella bortfall fick alla elever som var närvarande under matematiklektionen göra provet. För att inte störa den normala undervisningen och för att denna undersökning inte skulle ta eleverna ur sitt sammanhang hade vid detta tillfälle inga elever valts ut för kommande intervjuer. En annan anledning var att undvika bristande engagemang från elevernas sida. Alla elever som var närvarande fick en formativ återkoppling på sina inlämnade svar. 
Följande uppgifter gavs till eleverna:
Andreas och Lisa fick båda
löneförhöjning med lika många
kronor vardera. Andreas höjning
var $5 \%$ och Lisas var $2,5 \%$.
Undersök med beräkningar och
resonemang för vilka löner detta
kan vara möjligt. (NP, vt 2002)

\begin{abstract}
Anton ska jämföra kostnaden för att trycka reklamblad. Digitaltryckeriet tar en startkostnad på 20 kronor och sedan 24 öre per kopia. Tryckservice AB tar ingen
\end{abstract} startkostnad men tar 36 öre per kopia.

a) Skriv av tabellen och fyll i de värden som saknas. Endast svar krävs.

\begin{tabular}{|l|l|l|}
\hline Antal kopior & 100 & 500 \\
\hline $\begin{array}{l}\text { Kostnad hos } \\
\text { Digitaltryckeriet }\end{array}$ & & \\
\hline $\begin{array}{l}\text { Kostnad hos Tryckservice } \\
\text { AB }\end{array}$ & & \\
\hline
\end{tabular}

b) Anton har fått 320 kronor att använda till tryckkostnader. Hur många kopior från Digitaltryckeriet får han för denna summa?

c) Beskriv med en formel kostnaden för tryckning av $x$ reklamblad hos Digitaltryckeriet.

d) Hur många kopior måste man minst låta trycka för att Digitaltryckeriet ska bli billigare än Tryckservice $A B$ ?

Bedömningsexempel Matematik kurs 1b, PRIM-gruppen

Figur 2. Interventionsprov

Provförutsättningarna var enligt lärarens planering i fråga om tid, hjälpmedel etcetera. Lektionen var 60 minuter lång, vilket hade beräknats som tillräckligt. Emellertid visade det sig att vissa elever fick sitta över några minuter på den aktuella lektionen. 


\section{Bearbetning av elevernas svar på interventionsprovet}

Elevernas svar på provuppgifterna bedömdes utifrån vad teorier om formativ återkoppling säger om hur återkoppling bör ges till elever. Inför eleverna och för att inte förlora deras engagemang poängterades det att datainsamlingens fyra första steg var något som forskare och ordinarie lärare gjorde tillsammans. I praktiken var det dock jag som forskare som bedömde interventionsproven och läraren hjälpte mig med att plocka ut lämpliga matematikuppgifter och med att välja ut elever för intervjuer. En överenskommelse gjordes om att inga betyg eller poäng skulle delas ut på provet (se vidare i kapitlet Teoretiska utgångspunkter och tidigare forskning). Den formativa återkopplingen skrevs på dokument som bifogades elevernas inlämnade provpapper vid återlämnandet. Bedömningen fokuserade dels på de kvalitativa nivåer som finns uttryckta i kunskapskraven, dels på de förmågor som finns beskrivna i ämnesplanen, även om dessa begrepp inte levererades till eleven. Återkoppling till respektive elev skilde sig därmed åt $\mathrm{i}$ omfång och innehåll eftersom den anpassats efter elevens prestation.

\section{Skriftlig återkoppling kompletterat med muntliga frågor}

Efter att elevernas uppgifter bedömts fick de en skriftlig formativ återkoppling samt fick kort svara på hur de upplevde återkopplingen. Återkopplingen fick de en vecka efter att interventionsprovet genomförts. Det är svårt att ge några generella råd vad gäller timingen då en återkoppling bör ges (Black \& Wiliam, 1998; Brookhart, 2008; Hattie \& Timperley, 2007; Shute, 2008). Vidare kan en formativ återkoppling se ut på väldigt många olika sätt och man kan inte utifrån nuvarande forskning säga att det finns ett visst bästa sätt att ge återkoppling på (Shute, 2008). Det man har sett är att det är kvaliteten som är viktigast, det vill säga att den svarar på de tre frågorna: "Vad är målet?", "Var befinner sig elevens prestation i förhållande till målet?" samt "Hur ska eleven förbättra prestationen i riktning mot målet?". För att fånga elevernas första reaktion på återkopplingen småpratade jag med dem vid återlämnandet. Vidare ställdes frågor av typen: Hur känns det? Hur upplever du detta?

Följande kriterier har använts i utformningen av återkopplingen: Specifik, men inte för specifik, kopplad till en specifik uppgift, framåtsyftande, begriplig, levererad i rätt tid, individuellt anpassad och icke- 
värderande. Se vidare i kapitlet Teoretiska utgångspunkter och tidigare forskning.

\section{Bedömningsmatriser som grund för återkopplingen}

Elevernas lösningar har bedömts utifrån matriser med tre nivåer (A-, C-, och E-nivå), vilka har varit redskap för att ge återkoppling. Matriserna har hjälpt till med att identifiera kvaliteter i elevernas prestationer. Återkopplingen är baserad på de sju matematiska förmågorna som är framskrivna av Skolverket (Skolverket, 2011). Av dessa förmågor har sex använts, men återkoppling har inte getts i förhållande till alla eftersom det hade blivit för mycket information. För att minska informationsmängden och för att få eleven till att fokusera på det som är väsentligt har istället ett par aspekter valts ut där eleven visar på god förmåga (styrkor) och ett par aspekter där eleven visar mindre god förmåga (utvecklingsbehov). Bedömning har ofta ett stort inflytande på elevens fortsatta kunskapsutveckling och på elevens motivation och självuppfattning (Pettersson, 2005) och därför är det viktigt att visa på god förmåga.

Begrepp som står uttalade i matrisen har inte uttryckts i återkopplingen. Om till exempel en elevs lösning bedöms ligga på C-nivå i förhållande till aspekten/kriteriet problemlösning, är den generella formuleringen i matrisen: "Eleven kan formulera, analysera och lösa matematiska problem”. Dessa problem inkluderar flera begrepp och kräver avancerade tolkningar och detta kan eleven knappast förstå och omvandla till en strategi för att utveckla sin problemlösningsförmåga. Därför behöver denna bedömning transformeras till något som eleven kan förstå, till exempel genom att anpassa formuleringen till den aktuella uppgiften, liknande: "I den här uppgiften visar du att du kan ... genom att .... För att lösa den här typen av uppgifter på ett bättre sätt, kan du istället.... Detta kan du se i exemplet, där ....". Det tar oftast flera veckor för eleverna att själva lära sig tolka och förstå hur man använder en matris (Jönsson, 2010). I föreliggande studie har det inte funnits tid till att lära eleverna hur man tolkar och använder en matris och därför var det viktigt att återkopplingen var konkret.

Viktiga faktorer för att eleverna ska tillgodogöra sig återkopplingen Eftersom det visat sig att många elever inte klarar en alltför omfattande återkoppling (Shute, 2008) gjordes ett urval av kommentarer. 
Återkopplingen såg inte likadan ut för de olika uppgifterna i interventionsprovet. Dessa skilde sig angående struktur och hur pass tydligt styrkor och utvecklingsbehov var uttalade. En avvägning gjordes baserad på hur mycket information som jag trodde eleverna skulle kunna ta till sig.

För att eleverna skulle kunna tillgodogöra sig återkopplingen genomfördes följande steg:

1. Elevernas lösningar bedömdes utifrån matriser.

2. Ett par styrkor och ett par utvecklingsbehov valdes ut från bedömningen. Dessa styrkor och utvecklingsbehov gavs som en lägesbeskrivning till respektive elev.

3. Eleven fick hjälp till att kunna använda sin återkoppling för att förbättra sig. Det gjordes med hjälp av exempel som visade hur eleven skulle kunnat göra istället. Att enbart använda ord fungerar oftast betydligt sämre, speciellt om beskrivningen är generell och abstrakt (Shute, 2008).

Återkopplingen bör riktas på ett sådant sätt att man utmanar elevernas tänkande genom att tillföra andra infallsvinklar (Black m.fl., 2003; Nicol \& Macfarlane-Dick, 2006). Detta kan man göra genom att visa exempel på matematikuppgifter av olika kvalitet som eleven kan jämföra med sina egna uppgifter och diskutera dem. Lösningsexemplen på återkopplingen i föreliggande studie låg i linje med detta synsätt. I en förlängning skulle man även kunnat låta eleverna arbeta med att bedöma varandras arbeten, så kallad kamratbedömning (Nicol \& Macfarlane-Dick, 2006).

Sammanfattningsvis identifierades ett par saker som eleverna behövde förbättra genom tillämpning av följande steg:

1. Påpekande av vad det är som eleven gjort fel/mindre bra (lägesbeskrivning)

2. Beskrivning av vad eleven behövde utveckla

3. Visat exempel på hur det skulle kunnat se ut om man gjort det rätt/bättre 
Nedan ges exempel på delar av återkopplingen.

\begin{tabular}{|c|c|c|}
\hline \multicolumn{3}{|l|}{ Namn } \\
\hline 8.a.) & \multicolumn{2}{|c|}{$\begin{array}{l}\text { Digitaltryckeriet: } 44 \text { kr och } 140 \text { kr; Tryckservice: } 36 \text { kr } \\
\text { och } 180 \text { kr } \\
\text { Korrekt ifylld tabell. }\end{array}$} \\
\hline b.) & \multicolumn{2}{|c|}{$\begin{array}{l}\text { Du har ställt upp korrekt ekvation, utan att du löst den. Kolla } \\
\text { på detta lösningsförslag: } \\
y=\text { kostnad, } x=\text { antal ex } \\
y=20 \mathrm{kr}+24 \text { öre } x \\
\begin{array}{l}320=20+0,24 x \\
300=0,24 x \\
y=1250 \mathrm{st}\end{array}\end{array}$} \\
\hline c.) & \multicolumn{2}{|c|}{$\begin{array}{l}\text { K(x) }=\mathbf{2 0}+\mathbf{0 , 2 4 x} \\
\text { Inget svar. Har du ingen aning om hur du ska börja? Det är } \\
\text { okej att prova utan att veta. Kolla ovan formel. Hur känns } \\
\text { den? Kan du följa den? K(x) står för kostnad av x st reklam- } \\
\text { blad hos Digitaltryckeriet. }\end{array}$} \\
\hline d.) & \multicolumn{2}{|c|}{$\begin{array}{l}167 \text { blad } \\
\text { Se lösningsförslag för hur den elev (tidigare NP) sist i doku- } \\
\text { mentet har gjort. Vi ger tre lösningsförslag, prövning, ekvat- } \\
\text { ion och grafisk. Kolla efter och se vad som känns bäst för dig } \\
\text { att göra. }\end{array}$} \\
\hline \multicolumn{2}{|c|}{ Styrkor } & $\begin{array}{l}\text { Svårt att ange eftersom redovisning- } \\
\text { ar/uträkningar/tankar mm saknas. Du visar dock } \\
\text { att du kan ställa upp korrekt ekvation. }\end{array}$ \\
\hline \multicolumn{2}{|c|}{ Utvecklingsbehov } & $\begin{array}{l}\text { Du behöver arbeta med ekvationer. Du vet att du } \\
\text { får göra "precis" vad du vill med en ekvation så } \\
\text { länge du gör samma sak på båda sidor om lik- } \\
\text { hetstecknet va? Koncentrera dig sedan på den }\end{array}$ \\
\hline
\end{tabular}




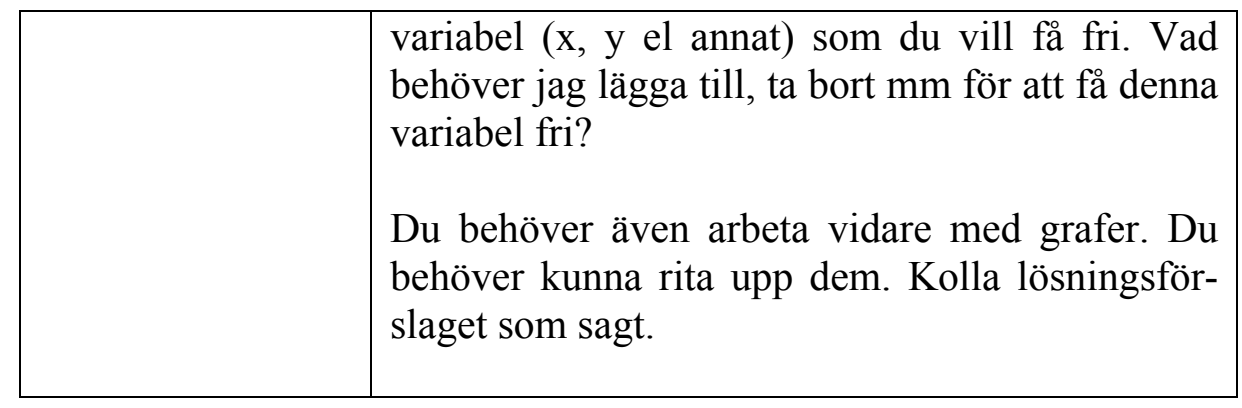

\begin{tabular}{|l|l|}
\hline Vad vi tycker du & Efter att du läst igenom kommentarerna är första \\
bör göra efter att & frågan vi tycker du ska ställa dig frågan om du \\
du fătt denna & förstått det vi skrivit. Vi tycker att du ska jämföra \\
återkoppling: & dina svar med lösningsförslagen och sedan tycker \\
& $\begin{array}{l}\text { vi att du ska göra om uppgifterna igen. Vi tycker } \\
\text { givetvis att du ska återkomma till oss om det är } \\
\text { några problem! }\end{array}$ \\
\hline
\end{tabular}

Figur 3. Delar av formativ återkoppling som eleverna fick

För mer utförlig och fler exempel på återkopplingen som eleverna fick se vidare i Bilaga 1-3.

\section{Ordinarie lärares prov}

Nästa steg i datainsamlingen var ordinarie lärares prov som gavs tre veckor efter interventionsprovet. Alla elever som var närvarande vid detta tillfälle genomförde provet, som bestod av uppgifter som matematikarbetslaget på skolan hade formulerat. För att elever ska använda sin återkoppling är det viktigt att de ges möjligheter till att använda den (t.ex. Brown \& Glover, 2006; Carless, 2006; Higgins m.fl., 2002).

\section{Urval}

Vid första steget i datainsamlingen, då provuppgifter delades ut till eleverna medverkade alla 25 elever som var närvarande vid det lektionstillfället. Efter detta tillfälle och inför bearbetning av elevernas svar valdes 15 elever ut. Antalet bestämdes med hänsyn till materialets omfång och den tid som var till förfogande. Tillsammans med läraren gjordes ett målinriktat urval med hänsyn till variation bland 
elevernas tidigare prestationer och deras prestation på interventionstestet samt elever som enligt lärarens uppfattning enbart var resultatinriktade eller inriktade på att lära sig.

Som grund för detta urval fanns en önskan om att upptäcka variation, få förståelse av och insikt i elevers upplevelser av en formativ återkoppling. Urvalet genomfördes med en önskan om att omfatta både lärandeorienterade och prestationsorienterade elever, det vill säga elever som tyckte att matematik var roligt, som ville lära sig mer och som var drivna av detta och elever som endast var prestationsintresserade, att det var prestationen i sig som var motiverande. Här var klassens lärare en viktig resurs genom att välja ut elever som matchade behovet. Elever med lärandeorientering var dock betydligt färre till antalet.

\section{Djupintervjuer}

Som det sista steget i genomförandet valdes 15 elever ut för intervjuer för att på djupet undersöka deras upplevelser kring denna formativa återkoppling. Valet av antal informanter gjorde att mer tid kunde ägnas åt förberedelse och analys av intervjuerna. I djupintervjuerna ställdes frågor med anknytning till hur eleverna kände, upplevde, uppfattade och förstod återkopplingen samt kring dess användande. Intervjuerna hade formen av vad Kvale och Brinkmann (2009) benämner den "halvstrukturerade livsvärldsintervjun", vilket i föreliggande studie innebar att målet var att få beskrivningar av elevernas upplevelser i syfte att tolka innebörden av dessa. Anledningen till att genomföra intervjuerna är att de är särskilt lämpliga när man vill beskriva människors upplevelser och styrkan ligger i anknytningen till intervjupersonens vardagliga undervisningssituation (Kvale \& Brinkmann, 2009). Intervjupersonernas svar följdes aktivt upp på ett så neutralt sätt som möjligt med ambitionen att deras uttalanden skulle klargöras och utvidgas. Den tidigare utformade intervjuguiden använde jag för djupintervjuerna. Intervjuerna skrevs ut och tillsammans med ljudinspelningen utgjorde detta det material som sedan analyserades. Jag följde guiden med avseende på de teman som togs upp, men ordningen och speciellt följdfrågorna varierade. Intervjuerna genomfördes på skolan och endast forskare och elev samtalade. Tiden vid varje tillfälle varierade mellan 30-60 minuter. Efter varje intervju ägnades några minuter 
åt att reflektera över omedelbara intryck och vad som lärts av intervjun.

\section{Hur den normala kontexten ser ut för eleverna}

För att få en bakgrund och därmed en djupare förståelse av elevernas uttalanden ges nedan en kortfattad presentation av klassen, deras ambitionsnivå samt deras ordinarie lärares försök till att arbeta med formativ bedömning. Detta ger en bild av lärarens undervisning och syn på bedömning i matematik, det vill säga en beskrivning av lärarens normala bedömningspraxis i matematik. Beskrivningen återfinns nedan och är skriven av elevernas ordinarie lärare och när det står "jag" eller "min" syftar det på läraren.

\section{Klassen}

Sammanhållningen i klassen är god och klassen som grupp är välfungerande. I klassen finns stora nivåskillnader i prestation både i matematik men även i antagningspoäng till gymnasiet. Flertalet elever i klassen nådde vid betygsättningen betyget $\mathrm{C}$ medan någon enstaka elev nådde betyget $\mathrm{B}$. Klassen tillhör en av de bättre jag har haft om man ser till betygsgenomsnittet eller antalet som nått $\mathrm{E}$ eller högre. Endast ett fåtal blev till slut underkända i kursen.

\section{Elevernas ambitionsnivå}

I många fall är ambitionsnivån ofta ganska låg. De flestas mål med kursen brukar vara att "få G". Även om det vid viss information brukar ändras till att "få E". Detta är dock inte en generell inställning utan jag har även elever i denna kurs med större ambitioner, även om dessa oftast uttrycks i termerna av vilka betyg de tänker sig. Sammanfattningsvis kan man om eleverna på skolan säga att det är bristen på motivation som är den mest avgörande faktorn till resultaten i matematik. I början av läsåret får eleverna redogöra för sina målsättningar i ämnet skriftligt. 


\section{Ordinarie lärares försök att arbeta med formativ bedömning}

Under åren har jag gjort flera olika försök till att skapa ett mer formativt arbetssätt. I min definition av detta ligger också att arbetssätten måste ligga inom vad som är möjligt för läraren att erbjuda i de ramar givna av organisationen. Det finns många aspekter om idag pockar på uppmärksamhet från läraren som man måste ta hänsyn till. Redan tidigt har jag försökt arbeta med tanken på prov som ett inlärningstillfälle där man måste på ett aktivt sätt ta del av hela produkten, provet, för att kunna se sin utveckling. Jag har provat många sätt för att åskådliggöra detta. Jag har till exempel bearbetat prov med hjälp av en matris där hela provet har varit i fokus, inte enskilda uppgifter. Intentionen i detta fall var att försöka få eleverna att se att poäng oftast är ett rätt trubbigt instrument. Det här arbetssättet har till viss del fått stryka på foten i de tidigare nivåerna av gymnasiematematiken eftersom det ofta kräver en mogenhet från eleven att känna sig trygg $i$ en egen reflektion av resultat som inte grundar sig i en konkret poängsumma och som sålunda inte ger ett skenbart objektivt svar. Min upplevelse av detta är att hur man än försöker arbeta ställer alltid eleven frågan "Men, blev jag godkänd då?" Detta gör att förändringsarbete ibland känns svårt att genomföra eftersom det blir mycket energi som går åt till att bryta ner tidigare inlärda strukturer. Speciellt på gymnasiet blir detta svårt eftersom fördomar ofta är djupt rotade och tiden man har att påverka eleverna ofta inte är längre än 80 lektionstimmar.

En del av arbetet jag gjort syftar också till att väcka elevernas självanalys vilket hos många elever känns som något väldigt ovanligt. Detta arbete har gjorts genom att eleverna själva ställer upp mål som sedan utvärderas i samband med prov. Utvärderingen har i vissa fall eleverna fătt stöd med och $\mathrm{i}$ andra fall inte. Att själv reflektera över sina fel och brister såväl som över sina starka sidor är inget de har erfarenhet av, i alla fall inte när det gäller matematik. Bilden är snarare att meningen med lektioner är att objektivt mäta dem mot en skala och placera in dem där. Ungefär som längdmätningen hos skolsköterskan. Detta har jag försökt arbeta mot genom att påpeka att inlämningsuppgifter och provs huvudsakliga syfte är att skapa ett material som syftar till självanalys. Lärarens användning av proven som betygsun- 
derlag ser jag som marginell, istället snarare som en konkret bekräftelse över vad jag redan anser om nivån. Prov blir alltså i huvudsak ett material som eleven och läraren kan mötas genom och diskutera och i vilka läraren kan exemplifiera de brister och de förtjänster som finns i elevens arbeten. Tyvärr tar detta sätt att arbeta mycket tid i anspråk och som det ser ut idag är det svårt att hinna med, inte för att arbetet inte är viktigt utan för att det tar stor enskild tid mellan lärare och elev i anspråk. Denna tid är värdefull, men som lärare är det svårt att sysselsättningen för resterande del av klassen under samma tid blir meningsfull.

För närvarande arbetar jag även inom regeringens fortbildningsprojekt matematiklyftet. Genom detta har jag fått en del nya insikter genom de samtal som förts med kollegor på arbetsplatsen.

\section{Sammanfattning av den normala kontexten}

Som man kan se ovan har läraren försökt att arbeta formativt genom olika möten med eleverna där elevernas utvecklingsbehov och förtjänster i deras arbeten diskuterats. Det arbete som gjorts har även syftat till att "väcka" elevernas självanalys, vilket har varit en svår uppgift eftersom det går åt mycket energi i form av exempelvis tid till att förändra elevernas sedan tidigare inlärda strukturer. Läraren har försökt få eleverna till att reflektera över sina fel och utvecklingsbehov samt även över sina starka sidor. Återkoppling har en nyckelroll inom formativ bedömning och en betydande roll när det gäller elevers uppfattning om sin förmåga och motivation för att lära (se t.ex. Black m.fl., 2003). Det är lärprocessen som är i fokus, det vill säga vart eleven ska och hur hon kommer dit hän hon önskar komma. I denna klass kan man dock enligt läraren se att eleverna inte primärt fokuserar på lärprocessen, utan istället på resultatet genom att ställa frågor som "men blev jag godkänd?"

\section{Analys}

Efter att intervjuerna genomförts startade en process med att försöka kategorisera elevernas uttalade upplevelser av den formativa återkopplingen. De inspelade intervjuerna (både de korta informella samtalen och djupintervjuerna) har transkriberats och det resulterade i runt 
150 sidor. Transkripten har analyserats och tolkats i flera steg. Det började med ett antal genomläsningar för att få en helhetsbild av intervjuerna och därigenom skapa en bild av varje elevs upplevelser och användande av den formativa återkopplingen. Därefter söktes och markerades utsagor som visade på elevers upplevelser och deras användande. Noteringarna var sedan ett stöd i processen för att lyfta ut relevanta uttalanden från eleverna.

En validering gjordes mot de ursprungliga transkripten för att se så att innebörden av urklippen inte tagits ur sitt sammanhang. Vid en analys kan det som i början uppfattats vara oväsentligt, senare komma att uppfattas som mycket väsentligt. Så har det inte riktigt varit här utan det som plockats ut vara väsentligt från början har fortsatt att vara väsentligt, men däremot har presentationen av detsamma ändrats en hel del allteftersom och förståelsen för det har även ändrats radikalt.

En del i studien har varit att presentera hur elever upplever fenomenet formativ återkoppling i matematik och detta har inneburit ett sökande efter innebörder istället för frekvenser. Som precis nämnts har resultatredovisningen inte handlat om att presentera resultat utifrån redan förutbestämda kategorier, utan en betydande del i forskningsprocessen har inneburit fortsatt tolkning av insamlad intervjudata. Dock har insamlad data tolkats med redan befintlig kunskap och tidigare referensramar. Studier av teorier om återkoppling och elevers motivation att lära sig matematik har varit en inspirationskälla för upptäckt av mönster som gett ökad förståelse.

Sedan har det handlat om ytterligare struktureringar av materialet som gjorts genom att jämföra och leta efter likheter och skillnader bland elevernas utsagor. Hela den analytiska processen har även pendlat mellan delar och helhet och mellan individ och grupp. Sökandet efter dessa likheter och skillnader har sedan resulterat i områden, som varit nära sammanbundna med forskningsfrågorna.

Elevernas samlade och uttalade upplevelser har analyserats och kategoriserats i olika grupper. Elevernas användande av den formativa återkopplingen har kategoriserats i grupperna Använder genom i huvudsak reflektion och Läser och reflekterar inte. Med begreppet reflektion menas huruvida eleverna gett uttryck för en eftertanke angående den egna prestationen, som till exempel "jag har missat detta i 
uträkningen, det måste jag tänka på nästa gång" eller "jag sökte inte efter hur man gör".

Elevernas målorientering har utifrån inledande allmänna frågor i intervjuerna angående matematik och undervisning i ämnet kunnat identifieras och detta har varit en primär faktor för vidare analys.

Kategoriseringen av elevernas målorientering gjordes genom en samlad bild av områdena:

- Huruvida eleverna tyckte det var viktigt att lära sig matematik

- Vad det var som drev dem till att gå till matematiklektionerna

- Vad de tyckte om ämnesinnehållet ekvationer, grafer och procenträkning (områden som behandlades på interventionsprovet)

- Om det var viktigt att lära sig det som de arbetade med i matematiken

- Om det var viktigt att klara av uppgifter med så lite arbete som möjligt

- Om det var viktigt att jämföra sig med andra

- Vad de tyckte om att visa sina uppgifter för andra

- Hur de brukar göra när de läser inför prov

En ytterligare analys har alltså sedan gjorts för att se eventuella kopplingar mellan elevernas upplevelser, hur de använt återkopplingen samt deras målorientering. Detta ger också svar på hur studiens delar, det vill säga upplevelser, användning och målorientering, samverkar och har lett till tre Elevprofiler. Elevprofilerna har konstruerats genom att gruppera elever med samma typ av målorientering och som har använt återkopplingen på motsvarande sätt. Sedan har skillnader i upplevelser både inom grupperna och mellan grupperna analyserats. Kategoriseringen är gjord utifrån hur eleverna upplevde återkopplingen och gjordes för att kunna diskutera materialet snarare än för att dra några statistiska slutsatser.

För att analysera samverkan mellan målorientering, användande och upplevelse har jag ställt dessa i avsnitt om två och två. Denna struktur underlättade analysarbetet genom minska det initiala antalet möjliga 
samband och därmed fick jag en struktur som var lättare och mindre komplex att angripa.

Studiens slutliga fyra huvudområden är elevernas upplevelser, användande, målorientering samt hur dessa faktorer samverkar.

\section{Etiska frågor}

Forskning inom utbildning innehåller ett antal etiska faktorer att förhålla sig till, bland annat förtroende, öppenhet, engagemang och sekretess. Dessa faktorer innefattar att visa respekt för individers rättigheter, vars privatliv inte ska invaderas, skadas, bedras, förrådas eller utnyttjas (Burgess, 1989). Eftersom undersökningen gjorts i en gymnasieklass har samtycke inte inhämtats från föräldrarna, utan endast eleverna har tillfrågats om de vill vara med och delta. Detta beslut har tagits enligt lagen om etikprövning (SFS 2003:406) och enligt denna lag behöver elever som fyllt 15 år inte ha föräldrarnas samtycke för att delta $\mathrm{i}$ en studie. Vid presentation av föreliggande studie för eleverna har studiens syfte delgetts. De fick information om att det var frivilligt att delta och de fick även noggrann information om att de kunde hoppa av utan att ange en anledning precis när de ville. Det insamlade materialet används endast i forskningssyfte. Elevernas och lärarens namn samt de inspelade och transkriberade intervjuerna har behandlats konfidentiellt. 


\section{Resultatredovisning}

I detta avsnitt ges en introduktion till resultatredovisningen och läsanvisningar. De följande avsnitten svarar mot studiens tre frågeställningar: 1) Hur eleverna upplever en formativ återkoppling 2) Hur eleverna använder en formativ återkoppling och 3) Hur elevernas upplevelser, deras sätt att använda återkopplingen och deras målorientering samverkar.

Först presenteras elevernas upplevelser av en formativ återkoppling i matematik. Därefter presenteras deras användning av densamma som följs av en redogörelse för elevernas målorientering. Centralt i föreliggande studie är: 1) Eleven, 2) återkopplingen och 3) individen i klassrumskontexten. Av dessa punkter har återkopplingen kunnat påverkas genom att den levererats enligt teorier om formativ återkoppling medan de andra två, det vill säga eleven och individen i klassrummet, inte har kunnat påverkas. I följande resultatredovisning redogörs för elevernas upplevelser utifrån individuella erfarenheter samt för elevernas individuella förhållningssätt (här i form av målorientering (MO)). Tre Elevprofiler konstrueras för att enklare kunna visualisera och diskutera huruvida elevernas upplevelser påverkar deras användande. I diskussions-kapitlet diskuteras klassrumskontext, individuella förhållningssätt och individuella erfarenheter som påverkar elevernas upplevelser och därmed deras användning av den formativa återkopplingen. Utgångspunkt för detta är den formativa återkopplingen som presenteras under kapitlet Metod och genomförande. Följande figur illustrerar detta samspel. 


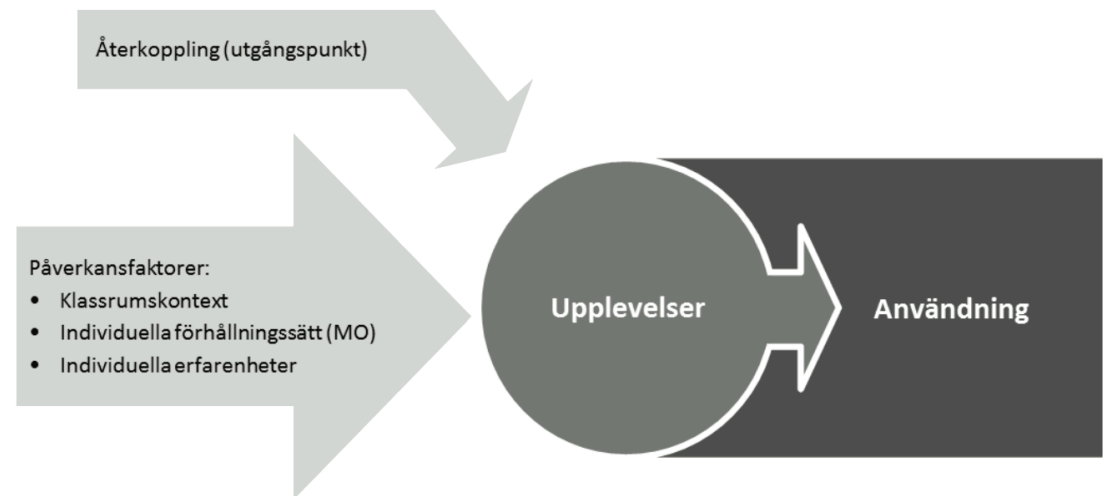

Figur 4. Påverkansfaktorer hypotiseras genom elevernas upplevelser, vilka i sin tur eventuellt påverkar användning

Man kan se att flera av citaten skulle kunna passa in i flera olika kategorier; dels beroende på att en del uttalanden i sig är flertydiga och därmed svåra att strikt klassificera, dels att uttalandena dessutom går in i varandra, vilket försvårar ytterligare. Detta kan alltså innebära att de utsagor som exemplifierar elevernas upplevelser och deras användande av återkopplingen i viss mån återkommer i mer än ett avsnitt.

Resultatredovisningen redogör för en samlad bild av elevernas upplevelser och hur de använde återkopplingen. Det fokuseras på ett brett spektrum av uttalanden istället för på hur många som sagt vad. Det är inte eleverna $i$ sig som studerats utan hur eleverna som grupp reagerade på en formativ återkoppling i matematik. Till exempel kan det finnas uttalanden från elever som upplevde att återkopplingen var användbar, även om de inte använde den under rubriken Aterkopplingen var användbar eftersom den hade fokus på vad de konkret behövde göra för att förbättra sina resultat. Individuella skillnader i upplevelser presenteras dock under avsnittet Hur elevernas upplevelser, användande och målorientering samverkar.

I citaten som följer finns två typer av markeringar. För att läsaren ska kunna skilja forskare och elever åt har eleverna fått en siffra inom parentes (avser inte antal elever) efter varje citat och forskaren ett $F$. Genom siffermarkeringen på eleven kan eleverna skiljas åt och det skapar möjlighet för läsaren att själv följa respektive elev. 


\section{Hur eleverna upplevde den formativa återkopplingen}

Upplevelse och uppfattning ligger nära varandra. Någon entydig definition av begreppet uppfattning har inte hittats i samband med föreliggande studie. Det finns de som hävdar att det utgör en del av attityder medan vissa menar att de inte alls har något gemensamt (Pehkonen, 2001). Enligt Pehkonen (1998) kan uppfattningar bland annat betraktas som individers erfarenheter och förståelse. Begreppet kan även innefatta självbild, aspekter av identitet och förtroende (Wedege \& Skott 2007). I föreliggande studie används begreppet upplevelse i form av elevers individuella erfarenheter och är $\mathrm{i}$ form av både känslor och värderingar.

Nedan grupperas och sammanfattas de olika upplevelser som eleverna hade. Grupperna återspeglar de övergripande upplevelserna och det innebär inte att alla upplevde samma sak.

\section{Återkopplingen var användbar eftersom den hade fokus på vad de konkret behövde göra för att förbättra sina resultat}

I detta avsnitt presenteras huruvida eleverna ansåg återkopplingen vara användbar eller inte. Deras faktiska användning av återkopplingen redogörs för i ett senare avsnitt.

Eleverna tyckte att denna situation kändes ny för dem, vilket gjorde att de inte visste vad de skulle göra med återkopplingen och det $\mathrm{i}$ sin tur påverkade hur de använde den. Under intervjuerna ökade deras förståelse för återkopplingen och de såg en klar användbarhet genom att den gav information om vad de behövde göra härnäst och att den gav konkreta råd för förbättring. Att den gav specifik information om elevens prestation och förslag på konkreta lösningsexempel var något som några elever tyckte var fantastiskt och ansågs vara precis det som behövdes, något som dock flera elever tyckte redan före intervjutillfället.

Några elever jämförde återkopplingen med lärarens genomgång på tavlan efter andra prov de haft och de tyckte att denna återkoppling var mycket bättre eftersom den fokuserade på den enskilda elevens prestation och inte var någon generell återkoppling som gällde för alla. Detta gav chans till att själv sitta och fundera och se efter hur 
man egentligen själv löst uppgiften. Enligt eleverna kunde lärarens provgenomgång på tavlan lätt få dem ointresserade eftersom den inte direkt är riktad mot elevens enskilda prestation. Vidare uppskattades återkopplingens koppling till särskilda uppgifter.

Många elever uttryckte att "man gör ett prov, får ett resultat och sedan går man vidare". Flera av eleverna tyckte att situationen med den formativa återkopplingen kändes som en engångsföreteelse och att "gjort är gjort". De tyckte att om de gjort ett prov och får tillbaka det och det är fel så är det inte så mycket de kan göra åt sitt resultat och då är det inte så lönt att arbeta vidare med uppgifter som man kommer lämna.

Eleverna tyckte också att återkopplingen var användbar i fråga om att rätta till fel och missuppfattningar även om det fanns ett par elever som sa att de inte behövde en sådan återkoppling, eftersom de redan visste vad de kunde och inte kunde och att det var upp till dem själva att själva ta reda på vad de behövde utveckla. Någon elev tyckte till och med att den inte var tydlig nog.

Några elever saknade att betyget inte var utskrivet, de tyckte att det medförde en osäkerhet kring var någonstans de låg på betygsskalan, men det fanns de elever som sa att det inte var så viktigt. Andra elever uttryckte istället att den formativa återkopplingen gav mer än poängsumma, som de annars var vana vid att få på prov.

Genom att den fungerade som en vägvisare (gav information om var jag är, vart jag ska och hur jag tar mig dit) och väckarklocka (pekade på det som behövdes respektive inte behövde göras härnäst) fick återkopplingen dem till att inse hur mycket den faktiskt kunde hjälpa dem till att utveckla sina prestationer. Eleverna uttryckte att det inte är lätt att göra något åt sin situation och därmed sitt slutliga resultat framöver om de inte får förklarat vad de gjorde för fel och vad de behövde förbättra. En ökad medvetenhet kring vad som krävs av dem, "vad vi som lärare vill ha" var också något som uppskattades och något som återkopplingen bidrog med.

Nedan redovisas några representativa citat:

Nej, jag tycker det är jättebra att man förklarar vad man gör fel och var man måste förbättra sig, så man vet själv. Om man inte vet det så är det inte så lätt att göra det då. (1) 
Jag ser inte mycket negativt i det. För mig var den en liten wake up call. Men det var inte negativ för mig på något sätt. Jag tyckte inte det blev något extra på det andra. Jag tyckte det var bra. Sen var det bra att göra den just då, för då behövde jag veta att jag skulle göra mer på grafer och då lärde jag mig mer om det och det var kanske det som saknades i min matte. (2)

Det står ju lite vad som krävs på uppgifterna. Och då förstod man att jag gjorde dem för simpla och då tänker man om det är så här man ska göra dem, jag har kollat väldigt mycket, i och med att jag gjorde inte alls så. Men i och med att man ska göra så här, då tänker jag, jamen då börjar jag göra så på framtida prov. Det sätter upp, just uppgifterna visar om hur man ska få nå sitt mål. (10)

Ja, alltså, det är ju större chans att jag övar på det jag behöver öva på om jag får en sådan här, för då vet jag ju mer konkret vad jag ska öva på, än när jag bara får poäng och så, så som vi brukar få. (13)

Ja det är ju bra om man behöver förbättra, om du här kan se att: "vi vill gärna se hela ovan uttryck", då vet jag, ja nästa gång måste jag uttrycka mig mer specifikt. Eller du skulle kunnat lösa denna uppgift annorlunda, så att man kan resonera kring vad man skulle kunnat göra annorlunda. (15)

\section{Elevernas motivation ökade när de blev medvetna om sin nuva- rande individuella situation}

För majoriteten av eleverna ökade motivationen när de blev medvetna om sin nuvarande individuella situation och vad som krävdes för förbättring av prestationerna. Framförallt handlar det om att det känns lättare att ta sig an uppgifter när man vet vad man ska göra. Hos vissa elever var dock den första känslan besvikelse.

Att återkopplingen angav styrkor motiverade dem. En elev uttryckte särskilt att detta är viktigt speciellt i matematik och att det skapade självförtroende till att vilja prova på uppgifter som man visste man var tvungen att ta tag i. En annan elev tyckte däremot tvärtom, att det var bra att återkopplingen inte bara fokuserade på vad som var bra, utan på vad eleven faktiskt behövde utveckla för att prestationerna i matematik skulle bli ännu bättre.

Prov som endast fokuserar på vad som var fel respektive rätt utan att ge förslag på förbättring skapar lätt en barriär för eleven till att ta tag $\mathrm{i}$ 
sina utvecklingsbehov eftersom det då känns som ett "berg som ska bestigas". Denna återkoppling banade istället väg för utveckling genom att de till exempel såg vad som hade utvecklingspotential och sedan kunde de jämföra sina behov med en alternativ lösning och därigenom se var och hur tidigt felen uppstod. Detta kändes bra eftersom det oftast inte är hela uppgifter som behöver vidareutvecklas. Preciseringen skapade även en vilja till att titta vidare på återkopplingen, på det man varit svagare på och den medförde att man mer tänkte över sina fel.

Nedan redovisas några representativa citat:

Ja det lyfter mig! Och det ger motivation till att jag vet vad jag ska jobba med, jag fick veta vad jag är bra på och vad jag ska göra för att förbättra det. (14)

Det kändes inte så att någon bara, uh, du är dålig på matte. Inte så. Men ändå att någon försökte hjälpa en. (8)

Jo mer motivation känner man, när man har varit på rätt väg. Här får man i alla fall reda på att här var det bra och där skulle du bara fortsatt lite mer så, att det kan man mer ta till sig. (12)

Det som jag tyckte var bra med detta, det var inte att nu så, ofta skriver man vad som är fel, men nu var det att man kände så att det var lönsamt när man fick detta, att det var bra du försökte lösa det grafiskt, då vet jag att jag gjorde det rätt alltså. Man blir glad, det är inte bara det negativa utan man får positiv respons om det negativa också, alltså på ett prov. (5)

\section{Det var en ny situation för eleverna och de förstod inte syftet}

Att det var en ny (kontextuell) situation skapade en förvirring som verkade leda till att syftet med återkopplingen gick eleverna förbi och gjorde en del elever tveksamma i början. Detta ändrades dock efter intervjuerna som gav tillfälle till att förklara situationen på ett djupare sätt. Ett par elever uttryckte att de inte trodde det skulle vara någon jättestor sak.

Flera av eleverna hade en syn på matematik som antingen rätt eller fel, det vill säga något som inte har olika kvaliteter som går att utveckla. Flera elever uttryckte till exempel att det bara är om svaret är rätt eller fel som räknas. De hade därmed svårt för att förstå poängen 
med återkopplingen, svårt för att tolka den och de förstod inte vad de utsattes för. Enligt någon elev kunde oförståelsen till varför de gjorde interventionsprovet vara anledning till att efterföljande återkoppling blev "konstig" och förvirrande. Några löste detta genom att prata med kompisen bredvid om hur man skulle titta. Elevernas reaktion visade att bedömning för dem inte handlar om att lära sig, utan om att visa vad man kan och att sedan få ett betyg utifrån detta. Med andra ord en summativ bedömning. Eleverna gör det "som man måste", "man gör det som räknas och syns" och i "matematiken gör man det inte för sin egen skull" och om det inte ska betygsättas förstärks detta scenario. De tyckte att det som de gjorde för deras ordinarie lärare var väl det som var det viktiga. Dessa elever såg inte att den formativa återkopplingen kunde gynna dem i sitt fortsatta lärande.

Flera elever upplevde den formativa återkopplingen som en tillfällig sak, vilket också gjorde att de inte ansträngde sig särskilt mycket. Eleverna tyckte att det kändes som att de fick återkopplingen och att det sedan inte var så mycket mer med det. En elev sa till och med att det kändes som att de endast gjorde det för forskningens skull. Enligt eleverna hade det varit önskvärt att det pratades mer med dem om återkopplingen och hur de skulle kunnat arbeta med den. I situationen då de fick återkopplingen hade de svårt för att se att den var användbar och att hela situationen var så ny för dem spelade roll.

Majoriteten av eleverna hade sett positivt på att arbeta på detta sätt framöver, men de lyfte även att det krävs en medvetenhet kring hur man ska använda återkopplingen och det var inte helt klart i detta läge eftersom de inte var vana vid denna typ av återkoppling. Eleverna efterlyste en upprepning av en sådan omfattande återkoppling och en integrering $\mathrm{i}$ den ordinarie undervisningen och därigenom skulle det bli en vana och de skulle förstått innebörden, vilket i sin tur skulle lett till en ökad användning. De efterlyste en regelbundenhet för att förändra denna, enligt eleverna, otrygga situation. Särskilt en elev lyfte vanan som trygghetsskapande och att man som elev vill känna trygghet och det gör man genom att bland annat veta hur lektionen ska se ut.

Dessutom skulle de fått tid till att ägna sig åt återkopplingen och läraren skulle poängterat hur viktigt det var och att det faktiskt skulle hjälpt dem. Eleverna var redan stressade inför det planerade provet de 
skulle ha, och för att de skulle vara i fas med lärarens planering, vilket de inte var och detta gjorde att de upplevde återkopplingen som ytterligare en sak som lades ovanpå en redan stressig situation. Eftersom det kändes som något som låg utanför deras ordinarie undervisning kunde det upplevas som att de inte behövde använda återkopplingen.

Eleverna efterlyste ett mer strukturerat arbetssätt med återkopplingen. De önskade till exempel sitta tillsammans med någon kompis och jämföra varandras återkopplingar. Vidare tyckte någon elev att det var så stökigt i klassen att hon inte kunde koncentrera sig. Andra elever sa att det sattes för liten press på att det här var viktigt.

Nedan redovisas några representativa citat:

Jag är inte så van vid det. Det kanske kan vara användbart om man vet hur man ska använda det. Men sen är det en helt ny grej, så då känns det lite främmande och då trycker man bort det helst. (3)

Det är väl så när man gjort ett prov, så känner man, åh, nu är det över. Man tänker inte, undra vad jag gjorde för fel så jag kan rätta till det. Utan det blir, jag har gjort det och kan inte ändra på det ändå. (5)

Får man detta ofta blir det en vana och då gör man det mer, alltså om det är en del av lektionen, för nu har det bara hängt här, ja kolla igenom det om ni känner för det, jag rekommenderar det, men det är ändå ert val och då blir det, jaha det har inte med lektionen att göra då behöver jag inte göra det. (5)

För jag är väl van att kolla på om jag fick fel eller rätt på provet. Det är typ det enda jag kollar på när jag får tillbaka prov. Vad fick jag rätt eller fel, vad fick jag för poäng. (10)

\section{Eleverna upplevde återkopplingen som skrämmande och de blev besvikna}

Eleverna fick formativ återkoppling utan att ha några större uppfattningar om vad det kan ge eller vad det går ut på. De fokuserade mycket på resultatet och var man inte nöjd kändes det som att man misslyckats. Några elever kände sig besvikna när de fick återkopplingen, eftersom resultatet inte var det de hade förväntat sig, de såg inte att det var den matematiska lärandeprocessen som var av vikt, utan fokus riktades mot resultatet och det var den känslan som "satte sig fast". Eleverna uttryckte att de var vana vid att man lämnar det man 
gjort och går vidare till nästa sak eller område och det medför att man inte riktigt vill tänka vidare på det som man har gjort när ett prov väl var över.

Ett par elever tyckte att det kändes "läskigt" när någon verkligen satte sig in i hur de tänkt och räknat, även om de flesta uttryckte att återkopplingen inte kändes dömande. För flera kändes det positivt att återkopplingen inte bara fokuserade på felen. I och med att den var så utförlig skapades en nyfikenhet på att se vad som hade kommenterats. Ett par elever kände dock tvärtemot att det var onödigt med en så pass utförlig återkoppling och att den inte gav dem någon ökad motivation till att titta närmre på det som hade utvecklingspotential i deras prestationer.

En elev ville "bara glömma bort" och det kändes "jobbigt" när det krävdes något av henne. Eftersom hon kände att hon inte klarade uppgifterna, att hon "failade totalt" (1) var det "jobbigt" att ta tag i återkopplingen och hon visste redan vad vi hade skrivit, det kände hon på sig.

Nedan redovisas ett par representativa citat:

Jag var lite besviken, för jag trodde jag hade fått till det bra, men det hade jag inte. Det var vad jag kände mest. (7)

Först var det lite läskigt, för man kände att någon verkligen, det är inte ofta att någon verkligen sätter sig in i det man har tänkt och räknat och så och, det här gjorde du bra och det här gjorde du inte bra. Verkligen så. Då tänkte jag, shit, detta är verkligen mycket och så, nej, nu blev det lite jobbigt. (8)

\section{Eleverna förstod inte återkopplingen}

Elevernas förståelse av återkopplingen genomsyrar studien och det finns ett tydligt mönster av att deras fokus låg på prestation och slutmål snarare än på processen att hjälpa dem till att nå en högre kunskapsnivå. Faktorer som inverkade på elevernas förståelse var återkopplingens form, struktur och innehåll, det vill säga matematiken som omfattades av återkopplingen.

Flera elever hade svårt för att tolka och förstå återkopplingen som de fick och kände sig förvirrade till en början. Efter att de hade läst ige- 
nom återkopplingen och förstått dess form och struktur så tyckte de att den var bra. Att återkopplingen var skriven på ett språk och på ett sätt som de förstod var också något som upplevdes som bra. Dock kändes det "jobbigt" att använda den eftersom det blev för mycket att hålla reda på. Någon elev efterlyste en genomgång av hur återkopplingen var upplagd. Några elever hade förslaget att de istället kanske kunde fått ett papper där det stod vad de borde tänka på eller en sammanfattning ihop med återkopplingen.

När frågor kring hur de upplevde återkopplingen ställdes så svarade de som om det gällde deras prestation på interventionsprovet och de fick ledas in på det som var av intresse för föreliggande studie.

Det är oklart huruvida eleverna fick ökad förståelse av matematiken som omfattades av återkopplingen, även om flera uttryckte att den hjälpte dem med att rätta till fel och missuppfattningar.

Nedan redovisas ett par representativa citat:

\begin{abstract}
Man hittade kanske inte var man hade gjort det och sen så måste man kontrollera där och sen så, var är den uppgiften. Det blir lite för mycket papper som man måste kontrollera. Och när det är en massa som händer runt omkring och sen fortsatta att fokusera, ja hur menar hon, vad gjorde jag för fel, att då blir det så himla mycket letande och kanske lite så, det kändes kanske lite för mycket då. (12)

Jag läste igenom först, för först fattade jag inte riktigt vad man skulle göra. Men sen så kollade jag uppgift för uppgift, vad jag skrivit och vad som var fel, vad som fattades och vad jag hade skrivit jämfört med rätta svaret. Så man fick nästan göra uppgift för uppgift för att fatta vad man själv hade gjort fel också. (9)
\end{abstract}

\title{
Eleverna upplevde det svårt att hantera återkopplingen
}

Här handlar det om hinder för att eleverna produktivt ska kunna använda den återkoppling som de fick. Eleverna gav uttryck för diffusa strategier, till exempel resonerade de att de själva måste engagera sig mer och jobba hårdare. Flera elever ville använda återkopplingen som en indikator på hur hårt man arbetat eller för att motivera sig själv. Dessutom hade de svårt för att prioritera återkopplingen eftersom de hade fokus på att hänga med i lärarens genomgångar och det som skulle arbetas med i läroboken. Någon uttryckte det som att det varit 
så många andra saker som man skulle göra, till exempel att hänga med på lektionerna och vara precis där de andra befann sig och att det var "jobbigt" att sätta sig ner själv med återkopplingen. En elev sa att han glömt bort att titta vidare på återkopplingen eftersom ingen tipsat honom om det. Istället kunde man fått tid till att sätta sig med en kompis och jämfört och samtidigt haft möjlighet till att fråga läraren och detta skulle gjorts direkt för att man inte skulle glömma bort hur man tänkt och gjort på uppgifterna. En annan elev uttryckte att "om man inte förstår så kanske man ska gå vidare till nästa sak istället" (3).

Eleverna uttryckte att det som de inte behövde göra det gjorde de inte, utan de gjorde enbart det som syntes. Majoriteten av eleverna försökte utveckla genvägar; det var inte processen som var det viktiga utan fokus låg på resultatet. Dock fanns det vissa elever som visste precis hur de skulle använda återkopplingen. Det kunde till exempel handla om att göra om uppgiften och att då tänka efter på de saker som kommenterats. En annan elev hänvisade till mängden, att hon inte tyckte det var så mycket att ta tag i så det var lika bra att göra det direkt. Vissa elever använde återkopplingen genom att göra det läraren sa till om eller det som de fått till sig.

Nedan redovisas några representativa citat:

Egentligen behöver jag jobba på mycket mer än vad jag egentligen gör. Men det är det att jag känner jag måste hänga med på lektionerna och vara precis där de andra är också, för att inte komma efter på andra punkter, och stressa och sånt. (6)

Satt för lite press på att detta var viktigt. Alltså vi fick tillbaka och sen var det inte så mycket mer med det. Man kunde kanske pratat mer om det och sånt. (3)

Alltså det är väl mest att man går vidare hela tiden, man har kanske inte tid att stanna och titta på varje, utan det går ju rätt snabbt i matten. (13)

När det gäller exempelvis matte, då känner man att man måste kunna detta, måste klara detta, och skiter i själva arbetet utan bara vill dit. (6)

Sammanfattningsvis kan det konstateras att eleverna tyckte att återkopplingen var användbar, men för att verkligen kunna använda den måste de veta vad de ska göra och hur de ska göra det. 


\section{Hur eleverna använde den formativa återkopplingen}

I följande avsnitt ges svar på elevernas faktiska användning av återkopplingen.

Alla eleverna gjorde något med återkopplingen, även om det varierade i vilken utsträckning de använt den. Variationen bestod av alltifrån att in i minsta detalj försöka förstå uppgifterna som gjorts till att läsa igenom återkopplingen sporadiskt ett visst antal gånger. Elevernas användning av den formativa återkopplingen har kategoriserats i grupperna Använder genom i huvudsak reflektion och Läser och reflekterar inte. Nedan kommer två avsnitt om hur eleverna använde sin återkoppling.

\section{Använder genom i huvudsak reflektion}

Elever i denna kategori har läst igenom återkopplingen och använt den genom att de reflekterat över och försökt förstå kommenterarna. Åtta av de elever som intervjuades använde återkopplingen på detta sätt. Det fanns ett par elever som skilde sig från de andra eleverna inom denna grupp genom att de dessutom använde återkopplingen genom att söka vidare efter ytterligare uppgifter där de kunde träna på de moment som hade utvecklingspotential eller bad de till och med deras lärare eller någon annan om hjälp. Eleverna använde återkopplingen genom att de först tittade på sina uppgifter för att se hur de räknade och sedan jämförde de med återkopplingen. För att förstå hur man kunde använda återkopplingen, vilket alltså först inte var helt lätt för de flesta, fick de först läsa igenom den och sedan kontrollerade de uppgift för uppgift. Någon uttryckte det som att "man nästan fick göra uppgift för uppgift för att förstå vad man själv hade gjort för fel", vilket kan förklaras av att återkopplingen inte enbart angav om uppgiften lösts rätt respektive fel. Det som sedan skilde mellan för eleven anpassat lösningsförslag på återkopplingen och elevens prestation reflekterade de sedan över på olika sätt. En reflektion kunde bestå av "men jag har missat den här raden i ekvationen, detta måste jag tänka på fastän det var rätt" (9). En annan kunde exempelvis lyda: "Jag brukar förklara vad jag skriver, men har nog kommit ifrån det lite. Detta kan jag nog bli noggrannare på, till exempel förklara vad $k$ och $x$ 
står för" (11). Någon uttryckte att hon i flera minuter reflekterat över vad hon gjort för fel innan hon kunde gå vidare till nästa uppgift.

Nedan kommer några citat som indikerar och illustrerar olika sätt att använda återkopplingen:

Jag läste igenom den och såg vad det var som var fel, jag kollade på alternativ man kunde göra och kände jamen just det. (1)

Jag kollade vad jag gjorde rätt och vad jag inte gjorde rätt. Även om det inte står förklarat här hur jag tänkte så får jag ändå, det är såhär man kan tänka för att. Sedan gick jag tillbaka till boken för att räkna några tal på detta. (2)

Jag läste den och sedan förstod jag hur jag skulle göra för att göra rätt. Jag gjorde inte om den. (13)

Jag försökte förstå det ni skrivit, och sen så vill man ju då få in den så snabbt $\mathrm{i}$ hjärnan så att man sen kan applicera den på något annat, det är väl det som är grejen med prov och så vidare, att man lär sig, och när man inte kan det så ska man lära det till nästa prov för att man sen ska kunna det. (15)

Men här har de tydligen gjort det här också, till exempelvis mer detaljerat och shit, då måste ju jag också göra det. Sen så bara, du behöver titta på grafiska lösningar och kunna rita upp grafer, vilket jag bara jaha, men, då gör jag det. (10)

\section{Läser och reflekterar inte}

Elever i denna grupp har endast läst igenom återkopplingen, antalet gånger skiftar dock, och de har inte gett uttryck för någon reflektion över det vi har kommenterat. Många har visserligen tänkt att i ett senare skede plocka fram återkopplingen, till exempel hemma, för att träna vidare eller inför nationella provet. Sju av eleverna hamnade i denna grupp.

Eleverna i denna kategori läste igenom resultatet och återkopplingen, men arbetade inte vidare med de saker som var av utvecklingskaraktär, även om det fanns en tanke om att göra det. Det var en elev som sa att han "inte brydde sig tillräckligt för att läsa återkopplingen en gång till” (4), men han läste igenom den två till tre gånger. En annan elev sa att hon inte hade orken till att använda återkopplingen på ett 
mer fruktbart sätt i den stunden och sedan ångrade hon sig när hon insåg att hon hade behövt det inför provet.

Nedan kommer några citat som indikerar och illustrerar olika sätt att läsa återkopplingen utan att reflektera över den:

Jag kollade på det, på lektionen, sen så tog jag hem det. Sen gjorde jag inte så mycket mer förutom att jag kollade igenom det en gång till, men det var inte så att jag sökte efter hur man gör, hur jag löser uppgifterna på nytt, när jag fick detta. (5)

Kollat på det, läste och jämförde och har sedan inte hunnit och det kändes som att jag vet vad jag ska göra och sen har jag inte gjort det. Så jag tänkte, detta var jättebra att få, för då blir det mycket lättare att se vad som, men det var svårt att, ja jag vet inte, jag gjorde bara inte det, gick inte igenom det igen. (6)

Jo, jag har ju tagit med mig lite av den, men jag har väl inte, jag har ju tittat igenom det och sen, jag vet inte, det blev liksom lite, man får den i skolan och så pratar man inte lika mkt om det längre, sen så blir det mer att man mer tänker på att fortsätta i den vanliga matteboken o sen så glömmer man bort det. (12)

Sammanfattningsvis kan det konstateras att hälften av eleverna inte använder återkopplingen utan läser den utan att reflektera och den andra hälften använder återkopplingen genom reflektion samt att det $\mathrm{i}$ sistnämnda grupp är stor spridning i hur mycket eleverna i denna grupp har använt och reflekterat kring sin återkoppling.

\section{Elevernas målorientering i matematik}

För att bättre förstå det som eleverna uttryckte, hur de sa sig uppleva återkopplingen och hur de använde den samt deras vidare tankar kring återkopplingen är det av vikt att även ha en bild över elevernas målorientering.

De flesta elever uttryckte att de hade prestationsmål, det vill säga att de hade en yttre motivation för att lära sig matematik. Flera av dem tyckte dock att det är bra att kunna matematik för framtiden, till exempel när man ska sköta sina bankärenden, men det var inte detta som i första hand drev dem till att gå till matematiklektionerna. Majoriteten av eleverna tyckte att matematik var, som de uttryckte det: "väl 
inte det roligaste precis". Flera av eleverna sa att "det som man kan är kul och tvärtom" och det var säkert en av anledningarna till det mål respektive elev hade med matematikundervisningen.

I nedanstående avsnitt ges en presentation av indelningen av eleverna med lärandemål respektive prestationsmål. I diskussionskapitlet diskuteras möjliga orsaker till elevernas målorientering.

\section{Lärandemål}

Tre av eleverna uttryckte lärandemål, det vill säga de gick till matematikundervisningen för att faktiskt lära sig, fastän vissa saker ibland kändes meningslösa, och för att de tyckte det var kul, även om detta skilde sig lite mellan eleverna. Den ena hade till exempel svårt för att se att något skulle vara onödigt att kunna i matematiken eftersom ingen vet hur framtiden kommer se ut och vad man då kommer att behöva. Två av eleverna i denna grupp tyckte alltså att matematik var "kul" medan den tredje inte tyckte det var "det roligaste som fanns". Sistnämnde elev ville lära sig för framtiden och gick till matematikundervisningen med anledning av detta. Han sa sig aldrig tänka på betyget även om han tyckte det var bra att ha bra betyg och det "får man ju om man bryr sig och om man pluggar" (15). Detta var dock inget han hade i åtanke utan "han gjorde sitt bästa" och sedan var han nöjd och visste han att han inte gjort sitt bästa fick han "plugga bättre nästa gång" så att det blev bättre.

Nedan redovisas ett par representativa citat:

Delvis för att man måste och sen för att man måste ha en grund att ligga på, alltså så att man vet vad man håller på med, sen när man blir vuxen med. Räkningar och, ja allt. Räntor, så man inte går på någon dålig fond eller sånt också. Räntor och grejer. (11)

Ja tycker det är roligt med matte, även om det är svårt ibland, så tycker jag det är roligt. Som estet så tycker jag om att se resultat. (2)

\section{Prestationsmål}

Elva elever uttryckte tydligt prestationsmål. Det mest framträdande var att de gick till matematikundervisningen eftersom de ville ha ett betyg för att kunna läsa vidare. Någon av eleverna låg lite mitt emel- 
lan. $\AA$ ena sidan pratade hon om hur viktigt betyget var för att komma in på hög-skola/universitet och att det skulle vara högt. Å andra sidan pratade hon om att hon faktiskt ville lära sig, men att hon ville lära sig behöver inte vara förknippat med att lära sig för framtiden utan att lära för att få ett betyg. Bland eleverna som uttryckte prestationsmål varierade sättet att ta sig an uppgifter. Vissa var rädda för att misslyckas, vissa ville inte visa sina uppgifter för andra, vissa tyckte inte det var lönt att försöka för att de ändå inte kunde, några orkade bara inte, någon tyckte att "det funkar" (3) och någon kände sig mest "plågad" (5) när hon gick till matematiklektionen. Några gjorde det till en tävling, till exempel sa en elev att det var jätteviktigt att jämföra sig med de andra, för "kan man matte är man smart" (10). Några ville dessutom "visa sin bästa sida" för läraren.

Nedan redovisas ett representativt citat:

Betyget. Det är efter betyget jag går. Ja, jag pluggar matte, och jag pluggar mycket för att få ett bra betyg. Jag bryr mig liksom inte om vad jag pluggar, det är bara betyget. Det är liksom inte så att jag känner shit vad glad jag är att få med detta i verkligheten, i framtiden. Utan jag hoppas jag får ett $\mathrm{C}$ nu, sen så känns det nästan som jag lägger det åt sidan. (10)

Sammanfattningsvis kan det konstateras att elva elever har prestationsmål och tre elever har lärandemål. Det förtjänar att förtydligas här att det redan i urvalet av elever ställdes önskemål om att få representanter med båda målorienteringar.

\section{Hur elevernas upplevelser, användande och målorientering samverkar}

Eleverna använde den formativa återkopplingen i olika utsträckning. Det är intressant att ta reda på vilka faktorer som verkar påverka deras användande. Jag hade en föreställning om att elevernas upplevelser av återkopplingen skulle påverka hur de använde den. Tyckte de att den var bra skulle det leda till att de använde den genom i huvudsak reflektion och vice versa. Flera av eleverna läste emellertid enbart igenom återkopplingen även om de tyckte att den var bra. Att återkopplingen upplevdes som bra innefattar att eleverna uppskattade dess fokus på styrkor, utvecklingsbehov, på elevens enskilda prestation och 
gav konkreta råd för förbättring (dvs. gav ökad motivation och var användbar). Noterbart är att det finns andra faktorer som påverkar om eleverna använder återkopplingen eller inte. Målorientering har varit en primär faktor eftersom elevernas målorientering på förhand varit bestämda. Dels genom teoretiska begrepp (på förhand definierade begrepp tillämpas) och dels genom att jag redan i urvalet av elever specificerat att jag velat ha elever med olika målorientering.

För att se hur faktorerna målorientering, användande och upplevelse samverkar har jag ställt dessa i avsnitt om två och två eftersom jag önskat fastställa huruvida det finns, respektive inte finns, samverkan mellan dessa. Detta har sedan utmynnat i tre Elevprofiler som beskriver samverkan mellan de tre faktorerna.

Nedan presenteras kopplingar mellan elevernas upplevelser, hur de använde återkopplingen samt deras målorientering.

\section{Kopplingar mellan hur eleverna upplevde och använde återkop- plingen}

Som tidigare konstaterats tyckte flera av eleverna att den formativa återkopplingen skapade en förvirring hos dem och att de inte visste hur och varför man skulle göra något med återkopplingen. Utifrån denna situation är det naturligt att återkopplingen blev något som eleverna inte prioriterade och som föll i glömska även om de egentligen tyckte att den var bra. Hos de elever som däremot inte alls uppfattade återkopplingen som förvirrande, utan bara något som var väldigt bra och något som var precis vad de behövde, det vill säga hos de elever som förstod poängen med återkopplingen, blev utfallet ett annat.

Nedanstående sammanställning visar om elevernas användande baserades på deras upplevelse eller om det fanns något annat som påverkade hur de använde återkopplingen. Sammanställningen gjorde det möjligt att se om det var någon grupp av elever som skilde sig från de andra. En grupp gjorde det och denna grupp analyserades vidare. Eleverna kategoriserades utifrån detta. Kategorierna har emellertid inte skarpa gränser utan någon elev återfinns i mer än en grupp. Grupperna skapades utifrån det mest framträdande bland elevernas uttalanden, det vill säga att återkopplingen upplevdes som bra och detta fick se- 
dan stå som modell för vidare gruppindelning. Siffrorna i parentes anger antalet elever per grupp.

\begin{tabular}{|l|l|l|}
\hline $\begin{array}{l}\text { Grupp } \\
1\end{array}$ & $\begin{array}{l}\text { Kategori } \\
\text { Upplevde återkopplingen som bra och använde den därmed }\end{array}$ & $\begin{array}{l}\text { Antal } \\
?^{*}\end{array}$ \\
\hline 2 & $\begin{array}{l}\text { Upplevde återkopplingen som bra och använde den oavsett (att } \\
\text { återkopplingen upplevdes som bra ej orsak till användning) }\end{array}$ & 2 \\
\hline 3 & $\begin{array}{l}\text { Upplevde återkopplingen neutralt (det kvittar, behöver ingen } \\
\text { sådan återkoppling och använde oavsett) }\end{array}$ & 2 \\
\hline 4 & Upplevde återkopplingen som bra, läste och reflekterade inte & $6^{* *}$ \\
\hline 5 & Upplevde återkopplingen som dålig, läste och reflekterade inte & 0 \\
\hline 6 & Upplevde återkopplingen neutralt, läste och reflekterade inte & 1 \\
\hline *: Osäkert hur många som hamnar här på grund av svårigheter med att entydigt uttyda ele- \\
vernas uttalanden \\
**: Tyder på att det är något annat som påverkar användning
\end{tabular}

Tabell 1. Sammanställning av elevernas upplevelser i olika kategorier

Fem elever placerades inte in eftersom det inte entydigt gick att uttyda deras uttalanden utifrån intervjuerna. De skulle antingen kunnat hamna i grupp 1, 2 eller 4. Man ser alltså att majoriteten av eleverna hade en positiv inställning till återkopplingen och flera av dessa elever använde den på något sätt. Det som är extra intressant är varför de elever som upplevde återkopplingen vara bra inte använde den. Det kan alltså konstateras att det inte räcker med att eleverna tycker att återkopplingen är bra. För de elever som tyckte att återkopplingen var bra, men inte använde den har det varit intressant att titta på skillnader och likheter i deras upplevelser och om dessa skilde sig från upplevelserna hos de som använde den. Vidare kan man även ställa sig frågan huruvida elevens målorientering påverkade användningen och hur detta i sin tur var kopplat till deras upplevelser.

Nedan följer en redogörelse över kopplingar mellan elevernas målorientering och användande och därefter vilka skillnader i upplevelser jag kunnat se. 


\section{Kopplingar mellan målorientering och användande}

Man kan tänka sig att elever med lärandemål är de elever som använder återkopplingen, eftersom de bland annat ser en ny möjlighet till att lära sig. Här kan det konstateras att alla elever med lärandemål använde återkopplingen. Troligen borde det även vara så att elever med prestationsmål använde återkopplingen eftersom dessa var ute efter ett bra resultat och det är 5 elever som hamnat i denna grupp. Det kan även konstateras att gruppen med prestationsmål och som inte använde återkopplingen sticker ut med 7 elever och frågan är varför dessa elever inte använde återkopplingen medan andra prestationsorienterade elever gjorde det. Detta diskuteras vidare under Vad som skilde grupperna åt. I tabellen ser man hur många elever som hamnat i respektive kategori.

\begin{tabular}{l|l|l}
\hline Målorientering & Kategori & Antal \\
\hline PM* $^{*}$ & Använde genom reflektion & 5 \\
\hline LM** $^{*}$ & Använde genom reflektion & 3 \\
\hline PM & Läste och reflekterade inte & 7 \\
\hline LM & Läste och reflekterade inte & 0 \\
\hline & \\
*: PM: prestationsmål & \\
**: LM: lärandemål &
\end{tabular}

Tabell 2. Antal elever i respektive kategori

Sammanfattningsvis använde samtliga elever med lärandemål återkopplingen. Då ingen variation återfinns i variablerna målorientering och användande skulle det kunna vara elevernas upplevelse av återkopplingen som avgör huruvida de använde återkopplingen, men detta går inte med säkerhet att fastställa.

Bland eleverna med prestationsmål kan det konstateras att återkopplingen i ungefär hälften av fallen ledde till användande medan den hos den andra hälften inte hade någon betydelse. Utifrån detta kan det konstateras att det fanns en typ av Elevprofil (Elevprofil 1), det vill säga en grupp av elever där de var lärandeorienterade, upplevde återkopplingen vara bra och som använde den i huvudsak genom reflektion. 
Det fanns alltså elever som hade samma målorientering (prestationsmål) och som upplevde återkopplingen som bra, men som ändå hanterade den olika. I nästa avsnitt presenteras skillnader i upplevelser mellan eleverna med prestationsmål (Elevprofil 2 och 3). Tanken är att ge en mer nyanserad bild för att kunna peka på skillnader i upplevelser bland dessa elever. Först kommer en sammanfattning av respektive grupps upplevelser. Det redogörs även för skillnader i upplevelser inom grupperna. Sedan görs en tolkning och därmed en presentation av skillnader av denna sammanfattning.

Sammanfattning av upplevelser från elever som använt återkopplingen genom i huvudsak reflektion (Elevprofil 2)

De elever som använde sin återkoppling genom att reflektera kring den, tyckte att återkopplingen var användbar. En elev skilde sig åt genom att inte önska upprepningar av den formativa återkopplingen eftersom hon inte tyckte att hon behövde en sådan återkoppling. Tre av eleverna tyckte att det kändes "jobbigt" av olika anledningar. Två tyckte att det var "jobbigt" av anledningen att det krävdes något av dem och en uttryckte specifikt att hon var lat. En elev tyckte det var "jobbigt" eftersom hon tyckte det var "läskigt" att någon satt sig in i vad hon gjort, även om hon sedan förstod att det var för att någon försökte hjälpa henne. En av eleverna blev besviken och ville bara glömma bort, de andra upplevde återkopplingen motiverande. En uttryckte att hon inte trodde det skulle vara någon jättestor sak och tre andra uttryckte tydligt att de inte förstod eller att de blev förvirrade då det var så nytt för dem. Endast en sa att de inte hade tid med denna typ av återkoppling och eftersom de hela tiden gick vidare enligt lärarens planering var det enligt henne viktigt att följa denna. Det var endast en som sa att det måste vara ett krav från läraren att använda återkopplingen om man ska använda den.

Sammanfattning av upplevelser från elever som läst sin återkoppling, men inte reflekterat över den (Elevprofil 3)

Även de elever som läst sin återkoppling, men inte reflekterat över den, upplevde återkopplingen som användbar, dock uttryckte de att det krävs att man förstår hur den ska användas och så var inte riktigt fallet. En sa dock att det "inte kändes lönt", eftersom han ändå inte kunde. Sex elever uttryckte att de antingen blev förvirrade eller att de inte förstod vad de skulle göra med återkopplingen eller hur de skulle 
använda den. Andra saker som uttrycktes var att det var nytt, att det kändes "konstigt", "främmande" och "ovant" och man ifrågasatte om det verkligen kunde hjälpa dem. Tiden upplevdes som ett problem för tre av dem, de ville inte ligga back i förhållande till planeringen och de tyckte att de måste få tid till att använda återkopplingen i skolan. Fyra elever sa att det kändes som att "gjort är gjort". En elev uttryckte att man gör det läraren ser, att man inte gör det för sin egen skull.

\section{Vad som skilde grupperna med prestationsmål åt}

Det som skilde grupperna åt var en tendens till att göra saker av andra skäl (för läraren eller matematiken) än för sin egen skull bland eleverna som enbart läste utan att reflektera. Tidsaspekten tycks vara viktigare för dessa elever än för eleverna som använde återkopplingen. En annan skillnad mellan grupperna är de som ser det som "gjort är gjort”. De antyder inte att de på något vis använder denna återkoppling i sin fortsatta inlärningsprocess. Det går inte att se några sådana tendenser till denna syn på återkoppling i gruppen som använde den.

Följande figur förtydligar de tre Elevprofilerna:

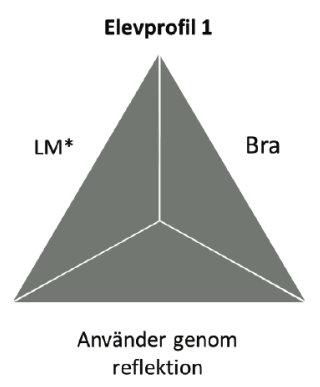

*: LM: lärandemål

**: PM: prestationsmål

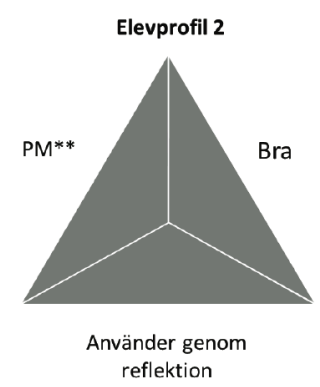

Figur 5. De tre Elevprofilerna

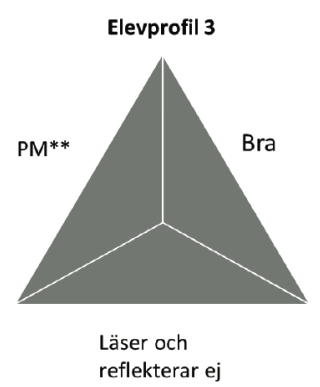

reflekterar ej

De tre elevprofilerna baseras på tre olika faktorer: (i) Vilken målorientering eleverna har, (ii) Hur eleverna använder sin återkoppling samt (iii) Hur eleverna upplever sin återkoppling. För Elevprofil 2 och 3 är variabel (i) fix (i detta fall lika med prestationsmål), variabel (ii) är dikotom (dvs. variabeln har bara två möjliga utfall) och variabel (iii) har antagit ett flertal olika värden (dvs. olika upplevelser). Givet dessa 
variabelvärden har en analys gjorts av huruvida det gick att hitta ett samband mellan variabel (iii) och variationen i variabel (ii). Det har inte gått att se några sådana samband och för att vidare kunna förstå denna skillnad har jag tagit stöd av ytterligare en teoretisk modell (Dual Processing Theory, Boekaerts, 1993), vilket diskuteras vidare i Diskussion.

\section{Kopplingar mellan målorientering och upplevelser}

Alla eleverna har inte upplevt återkopplingen på samma sätt. Det är även intressant att se om det finns någon skillnad mellan upplevelserna bland eleverna med prestationsmål respektive de med lärandemål. Eftersom det var så få elever med lärandemål är det inte så lätt att göra en jämförelse, men vissa saker kan ge en indikation.

Eleverna med prestationsmål har exempelvis upplevt återkopplingen på följande sätt:

Ville bara glömma bort, är jättebra att få förklarat vad som man gör fel och vad man måste förbättra, förvirrande, nytt, var jobbigt att läsa mycket, samma motivation som innan, kändes lönsamt att man lade all den tid, förstod inte, motiverande, läskigt, kändes som någon försökte hjälpa en, besviken, blev glad, tveksam i början.

Eleverna med lärandemål har exempelvis upplevt återkopplingen på följande sätt:

Var väldigt bra, såhär tydliga och bra återkopplingar har vi inte fått innan, skapar motivation, wake up call, precis vad man behövde då.

Eleverna med lärandemål nämnde inte några negativa upplevelser (som till exempel besvikelse, var mycket att läsa, förvirring och förstod inte) som eleverna med prestationsmål uttryckte. Dock nämnde de positiva saker (som till exempel att det skapar motivation, att det är väldigt bra att få en sådan återkoppling eftersom den är väldigt tydlig med att tala om förbättringar och hur man tar sig mot dessa förbättringar).

Uppfattningarna skilde sig inte särskilt mycket åt avseende huruvida de tyckte återkopplingen var bra eller varför den var bra.

Sammanfattningsvis var eleverna med lärandemål mer explicita vad gäller nyttoaspekten. De såg att återkopplingen gynnade dem och att 
detta var ett medel för att nå målen. Eleverna med prestationsmål lyfte saker av blandad karaktär varav mycket var av positiv karaktär, men även mer specifika upplevelser av känslomässig karaktär lyftes.

\section{De informella samtalen överensstämmer med djupintervjuerna}

Tanken med korta informella samtal var att fånga elevernas första spontana reaktioner då de fått tillbaka återkopplingen. Dessa samtal har även bidragit till en sorts kvalitetssäkring av det presenterade materialet. Innehållet i de informella samtalen skiljer sig inte nämnvärt från vad som kom fram i djupintervjuerna. Det lilla som framkom som nytt gentemot djupintervjuerna redovisas för här.

Eleverna hade inte trott att de skulle få så många kommentarer som de fick samtidigt som några uttryckte att de inte hade haft några större förväntningar eller att de inte visste vad de hade haft för förväntningar. Att det var "jobbigt" att bläddra mellan så många papper, mellan sitt eget och återkopplingen, togs också upp. 


\section{Diskussion}

Syftet med denna studie var att undersöka elevers upplevelser och användande av formativ återkoppling i matematik samt att se hur dessa samverkar tillsammans med elevernas målorientering. I detta kapitel diskuteras studiens resultat. Några aspekter, såsom klassrumskontext och elevens individuella erfarenheter samt dess individuella förhållningssätt, som visat sig ha betydelse för elevers användande av formativ återkoppling presenteras. Det finns en problematik i att veta vad som påverkar vad, till exempel påverkar individuella erfarenheter kontexten eleverna befinner sig i och vice versa, och därför har det i studien fokuserats på individen i kontexten istället för att separera dessa två. För diskussionsändamål fokuseras det här dock på antingen individuella eller kontextuella påverkansfaktorer. Sedan förs en diskussion kring studiens design och metoder. Slutligen följer summerande svar på forskningsfrågorna samt slutsatser och implikationer för undervisning och vidare forskning.

Vilken betydelse olika aspekter har för elevers användning av formativ återkoppling

De mest framträdande aspekterna - den individuella eleven, återkopplingens karaktär och kontexten eleverna befinner sig i - diskuteras nedan var för sig. Detta har gjorts för att få en tydlighet i diskussionen, men det bör påpekas att uppdelningen inte är helt trivial eftersom dessa aspekter har betydande inverkan på varandra.

\section{Den individuella eleven}

Vill vi få eleverna till att använda en formativ återkoppling måste vi få eleverna mer självreglerande, vilket innebär att de är autonoma och styr sitt eget lärande mot sina uppsatta mål (Butler \& Winne 1995; Hattie \& Timperley 2007; Black \& Wiliam 1998; Nicol \& Macfarlane-Dick 2006) Självregleringen består av elevernas målorientering uppdelat på lärandeorientering och prestationsorientering, motivation och värdering av uppgiften (Boekaerts, 1993). Självreglerande elever som förstod att återkopplingen kunde gynna dem i sitt lärande fann den användbar, även om vissa däremot inte kände sig beroende av så 
pass specifik återkoppling som gavs. De självreglerande eleverna berördes inte av kontextuella hinder (Corno, 1989) och de värderade uppgiften som positiv, vilket ligger i linje med Boekaerts teori (2001) om elevers värdering av matematikuppgifter och investering av möda.

\section{Målorientering - Prestationsinriktning}

Eleverna uttryckte framförallt prestationsmål, deras handlande utfördes på grund av yttre faktorer i lärandemiljön, istället för att vara lärandeorienterade (Boekaerts, 2001). Detta hör troligen ihop med deras ordinarie undervisning. En undervisning som har fokus på prestation, till exempel i form av poängsummor, betyg eller att man klarar proven, riskerar att driva fram en "prestationskultur" (Mendick, 2002). En undervisning som istället präglas av ett fokus på förståelse och formativ bedömning tenderar tvärtom att skapa annan motivation hos eleverna och därigenom andra typer av målorientering (Yates, 2000).

En elev med prestationsmål fokuserar på att visa sin kompetens (Dweck, 1986; Waege, 2007) och detta var framträdande i det empiriska materialet genom till exempel uttalanden om att det viktiga är om uppgiften är rätt eller fel och att det viktiga med undervisningen är att få ett betyg och gärna ett bra sådant. Dessutom gjordes uttalanden som "inom matematik gör man inte så mycket för sin egen skull", "det är något som man bara måste klara av" och då utan att fokusera på själva arbetet, utan istället på att uppnå resultat i form av betyg. Detta är exempel på det som Mellin-Olsen (1987) benämner instrumentell rationalitet, vilket betyder att eleverna vet att de behöver ha kunskap för framtiden eller åtminstone betyg i matematik för eventuella fortsatta studier. Med andra ord är det inte kompetensen som man vill utveckla, utan det handlar om att visa sin kompetens (Deci \& Ryan, 2000) och för några av eleverna är det dessutom viktigt att jämföra sig med andra. Detta är speciellt viktigt i matematik, eftersom man då anses som en kompetent person, eller som eleverna uttrycker det "väldigt smart". Begåvning anses vara något som är oföränderligt (Dweck, 2000). Alla elever med prestationsmål var inte lika, det vill säga deras användande av återkopplingen var olika autonomt reglerat och hälften av eleverna med prestationsmål använde återkopplingen och hälften läste utan att reflektera. En yttre påverkansfaktor hos elever med prestationsmål främjar dock inte den inre motivationen, vilket medför att dessa elever generellt har mindre intresse, svårare för ansträngning, 
får mindre positiva känslor och det leder till sämre prestationer (t.ex. Grouws \& Lembke, 1996; Hannula, 2006) och kan därmed vara en förklaring till att eleverna inte använde den formativa återkopplingen. Det kan konstateras att gruppen av elever med prestationsmål skilde sig åt och man kan också konstatera att det inom denna grupp fanns ett större motstånd gällande användande av formativ återkoppling, men där några av eleverna inte hindrades av detta motstånd.

Även om det inte har gått att precist särskilja de prestationsinriktade vad gäller prestationsinriktning med avoidance eller prestationsinriktning med approach (Elliot \& Harackiewicz, 1996) kan man se att vissa av eleverna inte hade tillit till sin förmåga och alltså hade sämre självförtroende. Vissa var rädda för att misslyckas och ville inte visa sina uppgifter för andra, vissa tyckte inte ens det var lönt och någon uttryckte till och med att det var "en plåga att gå till matematikundervisningen". Detta kan också vara en anledning till att återkopplingen inte använts eftersom deras föreställningar om den egna förmågan var negativa (Bandura, 1994).

Klassrumskulturen har en avsevärd roll (Harlen, 2006). Idag är det ett stort fokus på att klara av prov istället för att bli medveten om användbarheten och att skapa intresse för det som man lärt sig eller, för den delen, inte lärt sig. Läggs stort fokus på summativ bedömning och om återkopplingen består av betyg eller poäng på uppgifter som eleverna gör blir de prov- eller betygsorienterade snarare än lärandeorienterade, vilket i sin tur har en inverkan på deras motivation (Harlen, 2006).

\section{Målorientering - Lärandeinriktning}

De lärandeorienterade eleverna hade fokus på att utveckla sin kompetens, vilket stödjs av Deci och Ryans (2000) teorier om lärandeorienterade individer och de använde och implementerade återkopplingen i deras fortsatta lärande. Lärandemål tycks vara sammankopplat med hög kvalitet i lärandet gällande metakognition, ihärdighet och benägenhet att revidera befintlig kunskap vid osäkerhet (Ames, 1992; Pintrich \& De Groot, 1990), och lärandeorienterade elever har med andra ord inga problem med att exponera sin kunskap för att upptäcka och korrigera brister, vilket även gällde de lärandeorienterade eleverna $\mathrm{i}$ studien. 
De lärandeorienterade eleverna nämnde inte känslomässiga aspekter förutom motivation utan drog istället nytta av återkopplingen för att rätta till fel och missuppfattningar. Önskvärt är att få elever lärandeorienterade och detta är enligt Stipek med flera (1998) fullt möjligt. Detta leder i sin tur till att formativa återkopplingar används, i alla fall utifrån tidigare forskning som visar att dessa elever är mer benägna till att revidera missuppfattningar (t.ex. Ames, 1992) och så även i föreliggande studie.

Användandet av återkopplingen upplevdes som tillfredsställande på grund av värdet i sig självt eller för att man ville lära sig och förstå, vilket ligger i linje med Deci och Ryans (2000) definition på inre motivation. Vidare går detta att kopplas till social rationalitet (MellinOlsen, 1987), eftersom deras handlingar var knutna till ämnesinnehållet i sig, de fann matematik roligt eller intressant. Dock uppstår det en tveksamhet här då dessa elever visste att de hade nytta av matematik $\mathrm{i}$ framtiden och ett betyg däri och att de därmed behövde kunskapen.

\section{Motivation - Self-efficacy och positiva kommentarer}

Om en elev tror sig kunna gynnas av något så kommer hon gå in $\mathrm{i}$ lärandesituationen med hög motivation (Bergqvist mfl., 2009), vilket bekräftas av det empiriska materialet. Enligt litteraturen är även elevens tro på sig själv av betydelse (Bandura, 1984; Österholm, 2006), vilket i föreliggande studie visade sig när det handlade om att ta sig an uppgifter som återkopplingen berörde snarare än återkopplingen i sig. Några elever som läste igenom återkopplingen utan att reflektera var elever som "inte tyckte det var lönt eftersom de ändå inte kan", de kände besvikelse och en känsla av att ha misslyckats och det kan ha lett till undvikande beteende (performance avoidance goal, Elliot \& Harackiewicz, 1996). Detta stödjs även av Weimar (1985) som anser att det är viktigt att på sikt ha en god självkänsla inför sina prestationer, eftersom det bidrar till intresse för fortsättning och ansträngning i matematikstudierna. Förutom denna besvikelse kände eleverna förvirring inför återkopplingen eftersom det var en ny situation. Däremot fanns det elever som upplevde återkopplingen som positivt laddad och "pushande", men de använde inte den. I tidigare forskning har man sett att återkoppling i form av positiva kommentarer visat sig leda till färre ändringar (Ferris, 1997). 
Majoriteten av eleverna fick en ökad motivation eftersom de blev medvetna om sin nuvarande situation och vad som krävdes för förbättring av sina prestationer. Detta torde enligt Connell (1985) ha bidragit till att eleverna arbetade vidare med återkopplingen på grund av deras vetande angående orsaken till sina framgångar och misslyckanden. Så var däremot inte fallet bland alla elever. Att också ha en medvetenhet om styrkor borde också öka deras "self-efficacy" (deras föreställningar om sin förmåga) och därmed skapa motivation (Bandura, 1984). Avseende medvetenheten om styrkor respektive utvecklingsbehov går det att dra paralleller med Rakoczy med fleras (2013) syn på hur en formativ återkoppling i matematik kan stödja elevers lärande i matematik, nämligen genom att ge information om vilka av de matematiska strategier som behövs för att lösa en uppgift som har tillämpats korrekt av eleven samt om hur de matematiska lösningarna kan bli bättre. Som en parallell med Rakoczy med fleras (2013) studie kan det konstateras att ökad "self-efficacy" inte ledde till ökat användande av återkopplingen. Ökad upplevelse av användbarhet ledde till ökat användande för alla de elever som hade lärandeorientering samt för hälften av dem som hade prestationsorientering.

Det mest effektiva sättet att stärka tron på att man ska klara av något, enligt Bandura, är att vara med om saker som man klarar av. En återkoppling med klargörande av styrkor ger troligen en känsla av att man lyckats och därmed stärks ens upplevelse av förmågan att klara av saker och i sin tur även motivationen och flera elever tyckte sig uppleva detta. Flera elever tyckte också det var bra att återkopplingen fokuserade på vad som kunde utvecklas för att förbättra prestationen. Dessutom skapades självförtroende och en vilja till att prova på uppgifter som man visste att man måste ta tag i. Elevernas uttalanden går dock isär och utifrån detta går det inte att dra några slutsatser beträffande vad som påverkade vad.

Hittills har ett antal faktorer nämnts, som verkar ha haft betydelse för elevers användande av återkopplingen, men dessa är i sig självt inte tillräckliga.

Flera elever önskade en återkoppling med positiva kommentarer, i detta fall kommentarer som visade deras styrkor och den formativa 
återkopplingen uppfyllde detta. Tidigare forskning (Lipnevich \& Smith, 2009) har visat detta och då särskilt bland elever med låg självkänsla (t.ex. Pitts, 2005). Dessutom lyftes den utförliga responsen och engagemanget i elevernas prestationer som positivt.

\section{De tre Elevprofilerna}

Eleverna har använt den formativa återkopplingen i olika utsträckning. Det är intressant att ta reda på vilka egenskaper hos elever och undervisningssituationer som ger elever bra förutsättningar för lärande. Återkopplingen ledde antingen till att eleverna använde och reflekterade eller till att de läste utan att reflektera och eleverna har kunnat delas in i tre profiler. De elever som använde och reflekterade över återkopplingen var antingen lärandeorienterade eller prestationsorienterade och deras upplevelser skilde sig inte åt gällande återkopplingens användbarhet. Dock var eleverna med lärandemål mer explicita angående denna nyttoaspekt. De såg att återkopplingen gynnade dem och den var ett medel för att nå målen (Elevprofil 1). Som konstaterades ovan så ser man i föreliggande studie samma samband som i Rakoczy med fleras (2013) studie, att lärandeorienterade elever finner formativ återkoppling användbar och att de eventuellt därmed använder sin återkoppling.

Eleverna med prestationsmål lyfte saker av blandad karaktär varav mycket var av positiv karaktär, men även mer specifika upplevelser av känslomässig karaktär lyftes. Det som skilde eleverna som använt återkopplingen åt var deras målorientering. Man ser att eleverna med lärandemål drevs av inre motivation så som intresse och en vilja att lära sig, medan eleverna med prestationsorientering aktiverades av yttre faktorer, som betyg exempelvis. Vissa av dessa elever var trots allt självreglerande eftersom de använde återkopplingen och implementerade den i sitt fortsatta lärande men att de antog vägen som Boekaerts i "dual processing model" (1993) kallar "well-beingpathway" eftersom det handlade om ett undvikande av icke önskat resultat. Självregleringen skedde här "bottom-up" eftersom handlingen inte styrdes utifrån elevens egen vilja. Här är uppgiftens värde $\mathrm{i}$ förhållande till arbetsinsats av vikt (Eccles m.fl., 1983) och man ser att de elever som inte upplever återkopplingen som värd att investera $\mathrm{i}$ och därmed inte förstår dess potential därför inte nyttjar den i sitt fortsatta lärande utan bara väljer att läsa igenom den utan att reflektera 
(Elevprofil 3). Eleverna med lärandemål antog istället vägen "growthpathway" eftersom målet för dem var ökad kompetens (Boekaerts, 1993).

Man ser också att eleverna med prestationsmål och som använt återkopplingen investerade olika mycket i den och enligt Deci och Ryan (2000) finns det olika former av yttre motivation beroende på grad av autonomi eller självbestämmande målet skapar för eleven. Dock var det även några elever som inte använde och reflekterade över återkopplingen. När en elev inbjuds att delta $i$ en aktivitet värderar hon uppgifter utifrån nuvarande uppfattningar, kunskap och föreställningar, men även klassrumskontexten eleverna befinner sig i spelar en viktig roll för främjandet av självreglerat lärande (Zimmerman, 2002). Med tanke på detta är det inte konstigt att nya undervisningssituationer inte alltid faller helt väl ut. Dessutom visar tidigare forskning på att många matematikklassrum är annorlunda än andra klassrum genom att det bland annat finns ett stort fokus på korrekt svar och att dessa klassrum inte alltid främjar självreglerande elever (Havnes m.fl., 2012; Pintrich \& Wolters, 1998).

Skillnader man ser mellan Elevprofil 2 (prestationsinriktning och självreglerande) och 3 (prestationsinriktning och icke självreglerande) är att elever i profil 3 hade en tendens till att göra saker av andra skäl (för läraren eller matematiken, s.k. instrumentell rationalitet för lärandet (Mellin-Olsen, 1984, 1987)) än för sin egen skull, tidsaspekten tycks varit viktigare och det didaktiska kontraktet verkade vara viktigare med tanke på icke uppfyllda förväntningar. Vidare såg de på återkopplingen som "gjort är gjort", vilket troligen också har att göra med hur deras normala undervisning är uppbyggd eftersom de är vana vid att man går vidare från moment till moment. De visade med andra ord inte på något vis att de implementerade den formativa återkopplingen $\mathrm{i}$ sin fortsatta inlärningsprocess och denna syn kan inte ses i Elevprofil 2.

Något som också skilde grupperna åt var förmågan att kunna hantera och övervinna kontextuella hinder (Corno, 1989). Det verkar alltså främst vara den kontext eleverna befinner sig inom som är den faktor som hindrar eleverna i elevprofil 3 att utnyttja återkopplingen - framförallt verkar det inte vara eleverna som personer eller deras känslor. 
Utifrån föreliggande studie skulle man kunna tro att eleverna i Elevprofil 3 inte är intresserade av att lära sig och att det därmed inte spelar någon roll vilken återkoppling de får, vilket är fallet i Rakoczy med fleras (2013) studie. Däremot ser man i föreliggande studie att flera av eleverna som i början inte fann återkopplingen användbar och därmed inte implementerade den i sitt fortsatta matematiklärande fann den användbar när de väl förstod syftet med återkopplingen. Att arbeta mot vad Havnes (2012) med flera kallar "bedömning-för-lärandekultur" skulle kunna få dessa elever till att ta formativ återkoppling på allvar.

Sammanfattningsvis har det betydelse hur pass självreglerande den individuella eleven är. Självregleringen består i huvudsak av delarna målorientering, motivation och värdering av uppgiften. De lärandeorienterade eleverna var självreglerande och implementerade återkopplingen i sitt fortsatta lärande. Hälften av de prestationsorienterade eleverna gjorde samma sak. Den andra halvan gjorde det troligen inte på grund av kontextens negativa inverkan.

\section{Återkopplingens karaktär}

Att en återkoppling bör ges på både uppgifts- och processnivå, det vill säga att den ger svar på de tre frågorna ("Vart", "Var", "Hur") bekräftas i föreliggande studie (Hattie \& Timperley, 2007). Eleverna uppskattade en återkoppling som fokuserade på vad de behövde göra för att förbättra sina resultat. När eleverna blev medvetna om deras nuvarande prestationsnivå och vad de behövde göra för att förbättra densamma, det vill säga ett tydliggörande av Hattie och Timperleys tre frågor ökade motivationen för majoriteten av eleverna. Återkopplingen upplevdes som användbar i fråga om att rätta till fel och missuppfattningar och vad de behövde göra härnäst. Dock gäller det att eleverna får en möjlighet till att använda återkopplingen (vilket de i föreliggande studie fick) och att den erbjuder tillräckligt med information att agera utifrån, vilket också bekräftar tidigare forskning (Jönsson, 2012). Dock är inte detta tillräckligt. Flera elever uttryckte att man gör ett prov, får ett resultat och sedan går man vidare. De elever som först efteråt insåg dess användbarhet förstärker kontextens betydelse för elevers föreställningar om matematik och bedömning (Kloosterman, 
1996) och som därmed påverkade deras användande av formativ återkoppling. Genom ovan nämnda uttalanden om att lämna och gå vidare uttrycktes en brist på återkoppling på metakognitiv nivå där deras förmåga till att själva ta ansvar för att få återkoppling stärks (Hattie \& Timperley, 2007).

Återkopplingen innehöll alltså information som eleven kunde använda samt fokuserade på hur eleven skulle komma vidare (Wiliam, 2010), men har inte automatiskt lett till användande. Tidigare forskning tyder på att elever föredrar mycket återkoppling även om längden inte säger något om användande (Jönsson, 2012) och i föreliggande studie tyckte några av eleverna att det var mycket information att hålla reda på. Vilken betydelse detta har är däremot oklart.

En önskan om individuell återkoppling bekräftas från tidigare forskning (Jönsson, 2012). Däremot fanns det önskemål om att arbeta vidare med den tillsammans med någon annan och inte individuellt, eftersom de då inte lämnas ensamma att hantera återkopplingen. En regelbunden formativ återkoppling som är integrerad med undervisningen skulle troligen bidragit till detta önskemål.

Sammanfattningsvis kan återkopplingens karaktär beskrivas som dess användbarhet, det vill säga att skillnaden mellan elevernas matematikkunskaper och förväntade matematikkunskaper tydliggörs, den rättar till fel och missuppfattningar och är individuellt anpassad.

\section{Kontexten eleverna befinner sig i}

Kontexten har betydelse för elevers målorientering. Till exempel undervisningsmiljöer med tillåtande klimat gällande misstag eller otillräckliga lösningar främjar lärandeorientering och denna orientering utmanar i sin tur eleverna till att arbeta med utmanande uppgifter och till att våga ta risker (Resnick mfl., 1991; Stipek mfl., 1998). Därmed skapas en känsla av kompetens (Stipek, m.fl., 1998). Vad undervisningen lägger vikt vid har således betydelse. I föreliggande studie kan man i intervjuerna främst se att kontexten eleverna befinner sig i spelar roll eftersom det handlade om att visa vad man kan, det vill säga att ha rätt på uppgifterna. Vid fel på uppgifterna uttryckte flera elever besvikelse. Eleverna hade med andra ord fokus på resulta- 
tet snarare än på processen, vilket kan innebära att de befann sig i en kontext där inte misstag eller otillräckliga lösningar främjades.

Summativt förhållningssätt - Sociomatematiska normer och didaktiska kontraktet

Det rådde ett summativt förhållningssätt i klassrummet. Flera elever gjorde det som räknades och syntes, t.ex. uttrycktes "I matte gör man det inte för sin egen skull". Är svaret fel så "failar man totalt" och man vill "glömma bort det helt" och så vidare. Ett sådant fokus på resultat kan leda till undvikande av något negativt (Elliot \& $\mathrm{Mu}-$ rayama, 2008) och hör troligen samman med undervisningen eftersom det förhållningssätt till matematik, de sociomatematiska normer, som råder hos elever och lärare skapas $\mathrm{i}$ just matematikklassrummet (Engvall, 2013). Det mindre önskade resultatet leder också till minskad självtillit och därmed minskad motivation (Bandura, 1977).

Det fanns även elever som tyckte att det var lättare att veta var man befann sig i sitt lärande om man fick ett betyg utskrivet på provet och flera av dem sökte efter att använda den som en indikator på hur hårt man arbetat eller för att motivera sig själv, vilket även syns i Jönssons (2012) forskning. Då blir det också problematiskt om man varken får poäng eller betyg utsatta på återkopplingen. Denna önskan om betyg finner man i tidigare forskning (Brown, 2007), men i föreliggande studie är den inte särskilt uttalad. Dessutom fanns det elever som tyckte att den formativa återkopplingen gav mer än några poäng, vilket då i viss mån motsäger tidigare forskning.

Troligen är inte en återkoppling utan betyg eller en poängsumma av stor betydelse för dessa elevers användande, utan troligen är det andra faktorer, som till exempel ett summativt förhållningssätt som är avgörande. Detta summativa förhållningssätt leder som ovan nämnts till minskad självtillit och därmed minskad motivation. Man kan alltså se en samverkan mellan två perspektiv, det individuella/psykologiska och det sociala (Kazemi \& Stipek, 2001). Det summativa förhållningssättet måste utmanas, lärare och elever måste skapa ett nytt didaktiskt kontrakt eftersom denna kontextuella faktor verkar vara den som främst hindrar elevernas utnyttjande av en formativ återkoppling. Bedömning har alltså inget med lärande att göra och de har en syn på matematik som antingen rätt eller fel, det vill säga inte något som har 
olika kvaliteter som kan utvecklas. Detta gör det även svårt för eleverna att tolka och förstå den formativa återkopplingen.

Att eleverna hävdar "att det sattes för liten press på dem" motsäger tidigare hinder att överbrygga om att auktoritär återkoppling inte är produktiv (Jönsson, 2012). Dock kan även detta tolkas som tecken på att eleverna inte förstod återkopplingens syfte, som var att utveckla deras lärande, samt på deras föreställningar om matematik och bedömning som något som var rätt eller fel och att det inte handlade om att lära sig, utan om att visa vad man kunde och utifrån det få ett betyg, med andra ord summativ bedömning. Det kan även handlat om en önskan om att få dess vikt förklarad för sig, vilket åter hör ihop med förståelse. Elevernas föreställningar kan relateras till den undervisning de utsätts för (Cobb m.fl., 1992). Sammantaget verkar det i svenska matematikklassrum finnas ett fokus på procedurer i matematik och denna kultur påverkar elevernas syn på kunskap och lärande (Bergqvist m.fl., 2009; Björklund Boistrup, 2010; Skolinspektionen, 2009; Skolverket, 2003). Läggs istället fokus på processinriktat arbetssätt, vilket är fallet i vissa klassrum, skapas mer självreglering bland eleverna (Björklund Boistrup, 2010). Ett processinriktat arbetssätt ökar därmed möjligheter för att eleverna ska använda sin återkoppling, vilket i sin tur skapar möjlighet för ökat lärande i matematik.

Eleverna upplevde återkopplingen som en engångsföreteelse och de efterlyste en regelbundenhet, vilket visar på vikten av en återkopplings integrering i den ordinarie matematikundervisningen och dessutom var eleverna inte helt främmande vad gäller formativ bedömning. Havnes med flera (2012) bekräftar betydelsen av återkopplingspraktikens integrering i matematikundervisningen, men påpekar att en bedömningskultur med fokus på hur återkoppling bäst kan användas tar lång tid att utveckla. Eleverna hade problem med att veta hur de skulle hantera återkopplingen och tidigare forskning pekar på hur viktigt det är att elever lär sig hur man använder återkoppling (Burke, 2007), dessutom behöver tid ges för att stressade elever ska inse dess nytta, vilket i föreliggande studie yttrade sig genom ökad förståelse för återkopplingens användbarhet allt eftersom intervjuerna genomfördes eller hade genomförts. Denna förändring kändes otrygg eftersom det didaktiska kontraktet bröts (Brousseau, 1997) och bedömningen genom återkopplingen motsvarade inte det förhållningssätt med ett fokus 
på resultat och matematik som antingen rätt eller fel som normalt rådde och därmed bröts även de sociomatematiska normerna (Yackel \& Cobb, 1996).

\section{Det didaktiska kontraktet i praktiken}

Denna nya undervisningssituation skapade ett antal nya regler för undervisning och lärande i matematik och elevernas förväntningar stämde inte överens med denna nya situation. Elevernas "återkopplingsmiljö" behöver omarbetas så att lärarens och elevernas ömsesidiga förväntningar överensstämmer. Eftersom man så tydligt ser att kontexten har betydelse för hur eleverna använder sin återkoppling kan man dra slutsatsen att det inte bara är den enskilda "återkopplingsmiljön" som behöver förändras, utan hela undervisningsmiljön. Det handlar om att förändra faktorer i de didaktiska situationerna som kan framkalla de förändringar i elevens agerande som behövs för att det önskade lärandet ska äga rum.

Det är svårt att bedriva en undervisning som matchar alla elevers intressen och som ökar chanserna för användning av formativ återkoppling. Frågan är istället huruvida vi kan utföra aktiviteter, återkoppling i detta fall, utifrån yttre motivation, vilken bidrar till hög grad av autonomi och en känsla av kompetens och läraren har här en viktig roll. Att ge en återkoppling som formulerats enligt teorier om formativ återkoppling och som därmed bör gynna elever i deras lärande (t.ex. Shute, 2008) är grundläggande, men det finns även andra saker som vi bör tänka på om vi vill få återkoppling att fungera.

Sammanfattningsvis påverkade kontexten eleverna befann sig i deras föreställningar om matematik och bedömning negativt, genom att den tenderade att driva fram en prestationskultur som gjorde att eleverna hade fokus på resultat istället för på att lära sig.

\section{Styrkor och svagheter med studiens design och metoder}

I detta avsnitt resoneras kring studiens tillförlitlighet i relation till val av metoder, närhet $\mathrm{i}$ studiens fält och presentation av resultatet. Ett resonemang förs även om intervjun som metod och dess problematik. Empirins komplexitet har varit påtaglig och den beskrivs så utförligt som möjligt i analysavsnittet. 
Som forskare gäller det att sträva efter känslighet i fråga om fördomar (Kvale \& Brinkmann, 2009) och det gäller därför att beakta sin egen roll i den kvalitativa analysen av materialet så att den inte färgar resultatet och detta har jag tagit i beaktande genom att jag $\mathrm{i}$ alla delsteg försökt agera medvetet med detta $\mathrm{i}$ åtanke.

I föreliggande studie deltog 15 elever och på grund av det låga antalet deltagare gäller det att vara försiktig med att generalisera resultatet. Även om elever respektive klassrum är olika, finns det som tidigare nämnts en någorlunda gemensam bild över hur svenska matematikklassrum ser ut. Utifrån det resonemanget skulle liknande resultat sannolikt kunnat upprepas.

\section{Styrkor}

Att jag är lärare i matematik har hjälpt till i studiens designarbete genom att jag sedan tidigare har gett återkoppling och skrivit kommentarer till elever. Jag har således en tidigare förvärvad kunskap om matematik och bedömning i matematik, vilket har krävts för att kunna följa upp intervjupersonernas svar. Genom att kontrollera informationen med hjälp av följdfrågor stärks även validiteten. Att redan ha en förvärvad kunskap inom matematik och bedömning i matematik har dessutom bidragit till en kännedom om innehållet som man inte bara skaffar sig genom litteratur och teoretiska studier. Som Kvale (2009, s. 123) skriver: "Genom att hålla till $\mathrm{i}$ den miljö där undersökningen ska genomföras kommer man in i den lokala jargongen, de dagliga rutinerna och maktstrukturerna". Sammantaget har detta gett mig en känsla för vad intervjupersonerna talat om och jag tror att jag kunnat bemöta dem med en förståelse som inte skulle varit möjlig annars. I föreliggande studie sätts elevperspektivet $\mathrm{i}$ fokus och eleverna fick som undersökningspersoner komma till tals.

Liksom att det finns svagheter med intervjuer finns det även styrkor, till exempel att metoden uppmuntrar till längre och mer utförliga svar (Kvale, 2009), vilket är fallet här. Genom intervjuerna har jag fått djup och detaljer om elevernas upplevelser och tidigare erfarenheter kring återkoppling, som jag genom andra metoder (t.ex. enkät) inte skulle fătt. Detta djup har bidragit till ökad förståelse för elevers användande av återkoppling, som varit en komplex frågeställning, genom att jag fått ta del av elevernas resonemang kring frågan. Att ob- 
servera hur eleverna använde sin återkoppling skulle också varit svårt eftersom det inte skulle gett eleverna utrymme för att använda återkopplingen på det sätt som var naturligt för dem.

I studien presenteras data från olika moment - $\mathrm{i}$ form av provuppgifter, korta informella samtal och djupintervjuer - som tillsammans använts för att besvara forskningsfrågorna. I en kvalitativ studie gäller det att utförligt beskriva ställningstaganden gällande metodval, analys och så vidare, som forskaren gör under forskningsprocessen och förhoppningsvis förmedlas dessa så att hållbarheten kan bedömas (Kvale \& Brinkmann, 2009).

Att jag själv har formulerat återkoppling till eleverna istället för att använda lärarens återkoppling är en annan styrka eftersom det, som tidigare nämnts, inte alltid är säkert att förutsättningen finns för att återkopplingen ska fungera så som man skulle önska. Det är till exempel inte så att återkopplingen alltid beaktar Hattie och Timperleys (2007) tre frågor (vad, var, hur) och andra av de dimensioner som presenterats i föreliggande studie.

Genom att analysera elevernas målorientering, kontexten eleverna befinner sig i och deras upplevelser och användande av återkopplingen kan jag se hur dessa samverkar och få en stark empirisk studie.

För att säkerställa studiens validitet och reliabilitet har handledare och andra externa personer varit en viktig resurs i fråga om identifiering och tolkning av fenomen.

\section{Svagheter}

Jag behövde vara aktsam på att eleverna inte misstolkade intervjufrågorna, att de svarade på det som efterfrågades. När till exempel frågan "Hur kändes detta?" ställdes i samband med att de fått tillbaka den formativa återkopplingen fick jag vara observant på att det var upplevelsen av återkopplingen och inte upplevelsen av hur det gick på provuppgifterna som efterfrågades. Detta uppdagades dock under intervjuerna och i de fallen blev det tillfällen till att fråga om och ställa frågan på ett annat sätt. Jag har även fătt se upp med att inte ställa ledande frågor. 
Vad gäller reliabiliteten i intervjustudier bör man vara medveten om att intervjupersonerna kan komma att förändra sina svar under en intervju och de kan komma att ge olika svar till olika intervjuare (Kvale, 2009). Det kan till exempel vara så att elever svarar på ett sätt som de tror sig förväntas att svara. I föreliggande studie har jag inte kunnat validera elevernas svar utan fått utgå ifrån att deras svar var ärliga.

En annan svaghet kan vara kategoriseringen av till exempel elevernas målorientering och upplevelser där tolkningar utifrån elevernas uttalanden fått stå för respektive indelning. Detta är dock en del av forskningsprocessen och jag hoppas att en någorlunda klar bild förmedlas över hur kategoriseringarna är gjorda och att jag på så sätt mött denna problematik.

Även forskningskontexten kan relateras till det didaktiska kontraktet och elevernas normala kontext. För eleverna var det ett problem att jag inte var deras lärare och de ansåg sig inte ha tid med denna återkopplingssituation nu, eftersom det kändes som något som lades ovanpå deras ordinarie undervisning. Jag var inte deras lärare, men jag och deras ordinarie lärare försökte komma undan detta problem genom att vi tydligt inför eleverna poängterade att detta var något som vi gjorde tillsammans. Deras förväntningar på undervisningen krockade med det som skedde och därmed bröts det didaktiska kontraktet. Man kan diskutera hur stor påverkan jag som forskare hade på elevernas användande eller vilken effekt elevernas föreställningar om bedömning och deras syn på matematik hade. Eleverna uttryckte sig om att det inte var jag som skulle sätta betyget och utifrån detta kan man åter igen konstatera att ett resultatinriktat förhållningssätt rådde och att eleverna hade svårt för att tolka och förstå den formativa återkopplingen. Detta pekar på vikten av att förklara för eleverna varför arbetet är viktigt och det kan inte göras på annat sätt än att implementera formativ återkoppling i den ordinarie undervisningen.

Att som eleverna uttryckte det "det sattes för lite press på dem", att det inte var någon (helst läraren) som talade om för dem hur pass viktigt detta var och att det faktiskt skulle hjälpa dem kan också varit en metodologisk påverkansfaktor samt att det sedan dessutom inte följdes upp mer än vad som gjordes i intervjuerna. Dock tror jag att detta hör ihop med undersökningens faktiska resultat. Eftersom eleverna inte var vana vid att arbeta processinriktat förstod de inte återkopplingens 
syfte och att detta var något som kunde hjälpa dem framåt vad gällde den enskilda prestationen samt att detta inte är något som vid ett enskilt tillfälle kan påpekas och frambringa användande.

Till följd av detta kan man också diskutera huruvida man egentligen borde förklarat mer för eleverna hur de kunde arbetat med återkopplingen. Att eleverna inte förstod återkopplingen handlade inte så mycket om återkopplingens struktur och strategier för användande av densamma. Att ha en förståelse för återkopplingen leder troligen till ett utvecklande av strategier för användande. För att skapa förståelsen behöver återkopplingen vara nära sammanbundet med den normala undervisningskontexten och inget som man vid ett enstaka tillfälle kan uppnå.

Det fanns en osäkerhet redan från början angående hur mycket jag som forskare skulle prata om studien med eleverna så att forskningskontexten inte allt för mycket skulle separeras från deras vanliga undervisningskontext. I efterhand önskade jag att det varit möjligt att lägga en större vikt vid att följa upp återkopplingen, men detta är som sagt också en del av resultatet. Eleverna kände inte att de hade tid med något utöver det som de redan höll på med och flera påpekade att man hellre lade sin kraft på det som deras vanliga lärare hade planerat för. Trots dessa eventuella metodologiska påverkansfaktorer får man $\mathrm{i}$ empirin syn på många spännande tankar och upplevelser elever har kring en formativ återkoppling i matematik och på vad det är som krävs för att få en formativ återkoppling att fungera.

\section{Möjliga brister $i$ återkopplingens utförande}

Även om det inte finns något svar på hur en återkoppling bör se ut, finns det vissa saker i återkopplingen som är värda att lyftas. Texten "Efter att du läst igenom kommentarerna är första frågan vi tycker du ska ställa dig frågan om du förstått det vi skrivit" borde kanske ha uttryckts annorlunda eftersom det eventuellt kan uppfattas ha en nedlåtande ton. Eleverna borde kanske inte heller betts att göra om de uppgifter som kommenterats då det kan kännas som en bestraffning att räkna om en uppgift, som man dessutom fått facit på. Istället kunde vi hellre bett dem att till exempel skriva två saker på en lapp, som de skulle försökt tänka på nästa gång, och visat lappen för oss. Lösningarna som gavs på återkopplingen kan också ha uppfattats som det rätta svaret och inte som ett (bland flera) sätt att lösa uppgiften på. 
Tanken var först att välja ut "rika problem" (problem som är uppbyggda i olika steg och kan lösas på olika sätt och som skapar möjligheter till djupare diskussioner av matematiska begrepp, se vidare Hagland, Hedrén \& Taflin, 2005), men eftersom eleverna enligt läraren inte var vana vid att arbeta med denna typ av uppgifter valdes sådana uppgifter bort. 
Summerande svar på forskningsfrågorna samt slutsatser

- Hur upplever eleverna en formativ återkoppling?

Eleverna kunde uppleva återkopplingen som:

- Användbar, eftersom den hade fokus på vad de konkret behövde göra för att förbättra sina resultat

- Motiverande, eftersom de blev medvetna om sin nuvarande individuella situation

- Förvirrande, eftersom det var en ny situation för eleverna och de inte förstod syftet

- Skrämmande, eftersom någon på djupet analyserade deras svar

- En besvikelse, eftersom de hade fokus på resultatet och inte såg att det var den matematiska lärandeprocessen som var av vikt

- Svår att förstå, eftersom den var så omfattande och inte utformad på ett sätt de var vana vid

- Svår att hantera, eftersom de saknade strategier för att produktivt använda återkopplingen

Dessa upplevelser är i sig självt inte tillräckliga för att svara på varför eleverna använder respektive inte använder sin återkoppling. Se svaren på nästkommande forskningsfrågor.

- Hur använder eleverna en formativ återkoppling?

Av eleverna i studien använder hälften av eleverna återkopplingen genom reflektion och den andra hälften använder inte återkopplingen utan läser den utan att reflektera.

För majoriteten av eleverna ökar motivationen när de blir medvetna om sin nuvarande situation och vad som krävs för förbättring av prestationerna. För flera av eleverna handlar deras föreställningar om matematik och bedömning om att matematik är något som är rätt eller fel och inget som har olika kvaliteter som kan utvecklas. I de fall eleverna använder återkopplingen beror det i huvudsak på att de är självreglerande 
och inte hindras av kontextuella hinder såsom förändringar i undervisningen eller tidspress. De implementerar återkopplingen i sitt fortsatta lärande eftersom detta är målet för handlingen, antingen genom att man är intresserad eller för att man inser vikten av att lära sig för framtiden, men det kan även handla om att målet är att få betyg i ämnet.

I de fall eleverna inte använder återkopplingen beror det i huvudsak på att de inte är självreglerande och att de hindras av kontextuella hinder såsom förändringar i undervisningen och tidspress. De implementerar därmed inte återkopplingen i sitt fortsatta lärande.

- Hur samverkar elevernas upplevelser, hur de använder återkopplingen och deras målorientering?

Elever med lärandeorientering använde återkopplingen i huvudsak genom reflektion. Elever med prestationsmål hanterade återkopplingen på två olika sätt: (1) de läste och reflekterade inte eller, (2) de använde genom i huvudsak reflektion. Alla elever, oavsett målorientering, upplevde att återkopplingen var bra genom att den gav ökad motivation och att den var användbar.

För att använda återkopplingen verkar även andra faktorer påverka, så som att övervinna kontextuella hinder och att vara självreglerande genom att implementera återkopplingen i sitt fortsatta lärande.

Implikationer för undervisning och fortsatt forskning

Baserat på resultatet i denna forskning föreslås följande aspekter att ta $i$ beaktning för att få användande av en formativ återkoppling i undervisningen:

- Undervisningen behöver fokusera på processen istället för på prestationen (poängsummor, betyg etc).

- Återkopplingen måste vara väl integrerad i den dagliga undervisningen.

- Återkopplingen måste ges regelbundet. 
- Eleverna behöver ges möjlighet till att utveckla strategier för användning och därmed också till att göra rätt prioriteringar.

- Eleverna måste få en möjlighet till att använda den återkoppling de får och att de dessutom förstår syftet med densamma.

Det är viktigt att se om återkopplingen ger inverkan på elevernas framtida lärande och baserat på resultatet i denna forskning föreslås följande område för fortsatt forskning:

- Huruvida eleverna lärde sig något av återkopplingen, vilket skulle innebära en identifiering av situationer där eventuellt förbättrad förståelse synes vara en mer eller mindre direkt effekt av den formativa återkoppling eleverna fick. 


\section{Referenser}

Ames, C. (1992). Classrooms: Goals, Structures, and Student Motivation. Journal of Educational Psychology, 84(3), 261-271.

Bandura, A. (1977). Self-efficacy: Towards a unifying theory of behavioral change. Psychological Review, 84(2), 191-215.

Bandura, A. (1994). Self-efficacy. I V. S. Ramachaudran (Red.), Encyclopedia of human behavior (s. 71-81). New York: Academic Press.

Bandura, A. (1997). Self-efficacy: The exercise of control. New York: Freeman.

Bergqvist, E., Bergqvist, T., Boesen, J., Helenius, O., Lithner, J., Palm, T., \& Palmberg, B. (2010). Matematikutbildningens mål och undervisningens ändamålsenlighet: Gymnasieskolan hösten 2009. Göteborg: Nationellt centrum för matematikutbildning, Göteborgs universitet.

Björklund Boistrup, L. (2010). Assessment discourses in mathematics classrooms: a multimodal social semiotic study. Doktorsavhandling, Stockholm: Stockholms universitet.

Björklund Boistrup, L. (2012). Bedömning i matematikklassrum - för elevers engagemang och lärande (film). Hämtad 2012-12-15, från http://matematikutvecklare.ncm.gu.se/?q=node/165.

Björklund Boistrup, L., \& Selander, S. (2009). Coordinating multimodal social semiotics and an institutional perspective in studying assessment actions in mathematics classrooms. I V. Durand-Guerrier, S. Soury-Lavergne \& F. Arzarello (Red.), Proceedings of CERME 6, Sixth Conference of European Research in Mathematics Education (s. 1565-1574). Lyon, France: Institut national de recherche pédagogique.

Black, P., \& Wiliam, D. (1998). Assessment and classroom learning. Assessment in Education: Principles, Policy \& Practice, 5(1), 7-73.

Black, P., \& Wiliam, D. (1998). Assessment and classroom learning. Assessment in education, 5(1), 7-74. 
Black, P., \& Wiliam, D. (2006). Developing a theory of formative assessment. I J. Gardner (Red.), Assessment and Learning (s. 81-100). London: Sage.

Black, P., \& Wiliam, D. (2009). Developing the theory of formative assessment. Educational Assessment, Evaluation and Accountability, 21(1), 5-31.

Black, P., Harrison, C., Lee, C., Marshall, B., \& Wiliam, D. (2003). Assessment for learning: Putting it into practice. Buckingham: Open University Press.

Blomhøj, M. (1995). Den didaktiske kontrakt i matematikundervisningen. Kognition og poedagogik, 4(3), 15-25.

Boaler, J. (1997). Experiencing school mathematics. Buckingham: Open University Press.

Boekaerts, M. (1993). Being concerned with well-being and with learning. Educational Psychologist, 28(2), 149-167.

Boekaerts, M. (1999). Self-regulated learning: Where we are today. International Journal of Educational Research, 31(6), 445457.

Boekaerts, M. (2001). Context sensitivity: Activated motivational beliefs, current concerns and emotional arousal. I S. Volet \& S. Järvelä (Red.), Motivation in learning contexts: Theoretical advances and methodological implications (s. 17-31). Oxford, England: Pergamon.

Boekaerts, M. (2006). Self-regulation and effort investment. I K.A. Renninger \& I.E. Sigel (Red.), Handbook of child psychology: Vol. 4. Child psychology in practice (6th ed., s. 345-377). New York: Wiley.

Brookhart, S.M. (2007). Expanding Views About Formative Classroom Assessment: A Review of the Literature. I J.H. McMillan (Red.), Formative Classroom Assessment: theory into practice. New York: Teachers college, Columbia University.

Brookhart, S.M. (2008). How to give effective feedback to your students. Alexandria, VA: Association of Supervision and Curriculum Development. 
Brousseau, G. (1997). The theory of didactical situations in mathematics. Dordrecht: Kluwer Academic Publishers.

Brown, E., \& Glover, C. (2006). Evaluating written feedback. I C. Bryan \& K. Clegg (Red.), Innovative Assessment in Higher Education (s. 81-91). London: Routledge.

Brown, J. (2007). Feedback: The student perspective. Research in Post-Compulsory Education, 12(1), 33-51.

Burgess, R. G. (1989). Grey areas: Ethical dilemmas in educational ethnography. I R. G. Burgess (Red.). The Ethics of Educational Research (s. 60-76). London: Falmer Press.

Burgess, R. G. (1991). In the Field. An introduction to Field Research. London: Routledge.

Burke, D. (2007). Engaging Students in Personal Development Planning: Profiles, Skills Development and Acting on Feedback. Discourse, Learning and Teaching in Philosophical and Religious Studies, 6(2), 107-142.

Butler, D. \& Winne, P. (1995). Feedback and self-regulated learning: A theoretical synthesis. Review of Educational Research, 65(3), 245-274.

Butler, R. (1988). Enhancing and undermining intrinsic motivation: the effects of task-involving and ego-involving evaluation on interest and performance. British Journal of Educational Psychology, 58(1), 1-14.

Carless, D. (2006). Differing perceptions in the feedback process. Studies in Higher Education, 31(2), 219-233.

Chanock, K. (2000). Comments on essays: Do students understand what tutors write? Teaching in Higher Education, 5(1), 95105.

Cobb, P. \& Yackel, E. (1996). Constructivst, Emergent, and Sociocultural Perspectives in the Context of Developmental Research. Educational Psychologist, 31(3-4), 175-190.

Cobb, P. (1985). Two children's anticipations, beliefs, and motivations. Educational Studies in Mathematics, 16(2), 111-126. 
Cobb, P., Wood, T., \& Yackel, E. (1993). Discourse, mathematical thinking and classroom practice. I E. A. Forman, N. Minick, \& C. A. Stone (Red.), Contexts for learning: Sociocultural dynamics in children's development (s. 91-119). New York: Oxford University Press.

Cobb, P., Wood, T., Yackel, E., \& Perlwitz, M. (1992). A follow-up assessment of a second-grade problem-centered mathematics project. Educational Studies in Mathematics, 23(5), 483-504.

Corno, L. (1989). Self-regulated learning: A volitional analysis. I B.J. Zimmerman \& D.H. Schunk (Red.), Self-Regulated Learning and Academic Achievement: Theory, Research, and Practice (s. 111-141). New York: Springer-Verlag.

Corno, L. (2001). Volitional aspects of self-regulated learning. I B.J. Zimmerman \& D.H. Schunk (Red.), Self-regulated learning and academic achievement: Theoretical perspectives (2:a upplagan, s. 191-226). Mahwah, NJ: Lawrence Erlbaum.

Covington, M. V. (2000). Goal theory, motivation, and school achievement: An integrative review. Annual review of psychology, 51(1), 171-200.

Deci, E. L. (1975). Intrinsic motivation. New York: Plenum Press.

Deci, E. L., \& Ryan, R. M. (1985). Intrinsic motivation and selfdetermination in human behavior. New York: Plenum.

Deci, E. L., \& Ryan, R. M. (2000). The "What" and "Why" of Goal Pursuits: Human needs and the Self-Determination of Behavior. Psychological Inquiry, 11(4), 227-268.

Deci, E.L., \& Ryan, R.M. (1994). Promoting self-determined education. Scandinavian Journal of Educational Research, 38(1), 314.

Dweck, C. S. (1986). Motivational Processes Affecting Learning. American Psychologist, 41(10), 1040-1048.

Dweck, C.S. (2000). Self-theories: Their role in motivation, personality and development. Philadelphia: Psychology Press.

Dweck, C.S., \& Legget, E.L. (1986). Motivational processes affecting learning. American Psychologist, 41(10), 1040-1048. 
Eccles, J. S., \& Wigfield, A. (2002). Motivational beliefs, values, and goals. Annual review of psychology, 53(1), 109-132.

Eccles, J.S. (1983). Expectancies, values, and academic behavior. I J.T. Spence (Red.), Achievement and Achievement Motives (s. 75-146). San Francisco: Freeman.

Eccles, J.S. (1984). Sex differences in achievement patterns. I T. Sonderegger (Red.), Nebraska Symposium on Motivation, (Vol. 32, s. 97-132). Lincoln, NE: University of Nebraska Press.

Elliot, A. J. \& Murayama, K. (2008). On the measurement of achievement goals: Critique, illustration, and application. Journal of Educational Psychology, 100(3), 613-628.

Elliot, A. J. (2005). A Conceptual History of the Achievement Goal Construct. I A. J. Elliot \& C. S. Dweck (Red.), Handbook of Competence and Motivation (s. 52-72). New York: The Guilford Press.

Elliot, A. J., \& Harackiewicz, J. M. (1996). Approach and Avoidance Achievement Goals and Intrinsic Motivation: A Mediational Analysis. Journal of Personality and Social Psychology, 70(3), 461-475.

Elliott, E. S., \& Dweck, C. S. (1988). Goals: an approach to motivation and achievement. Journal of personality and social psychology, 54(1), 5.

Engström, A. (2004). Lärarkunskap och matematikdidaktisk kompetens. Paper presenterat vid LUMA 2004, Göteborg, september, 22-24. Hämtad 2014-09-10, från http://ncm.gu.se/media/ncm/komputv/luma04/LUMA\%202004\%20engstrom.pdf.

Engvall, M. (2013). Handlingar i matematikklassrummet. En studie av undervisningsverksamheter på lågstadiet då räknemetoder för addition och subtraktion är i fokus. Doktorsavhandling. Linköping: Linköpings universitet. 
Wedege, T., \& Evans, J. (2004). Motivation and resistance to learning mathematics in a lifelong perspective. I J. Evans, \& T. Wedege (Red.), TSG6 Adult and Lifelong Mathematics Education.

Ferris, D. (1997). The influence of teacher commentary on student revision. TESOL Quarterly 31(2), 315-39.

Gibbs, G. \& Simpson C. (2004). Conditions under which assessment supports students' learning. Learning and Teaching in Higher Education 1(1), 3-31.

Gipps, C. V. (1994). Beyond Testing: Towards a Theory of Educational Assessment. London: RoutledgeFalmer.

Goodchild, S. (2001). Students' Goals. A case study of activity in a mathematics classroom. Norway: Caspar Forlag.

Goodman, J., Wood, R. E., \& Hendrickx, M. (2004). Feedback Specificity, Exploration, and Learning. Journal of Applied Psychology, 89(2), 248-262.

Graham, S., \& Weiner, B. (1996). Theories and principles of motivation. I D. C. Berliner \& R. C. Calfee (Red.), Handbook of educational psychology (s. 63-84). New York: Simon \& Schuster Macmillan.

Grossman, P. \& Stodolsky, S. (1994). Considerations of content and the circumstances of secondary school teaching. I L. DarlingHammond (Red.), Review of Research in Education, (Vol. 20, s. 179-221). Washington, DC: American Educational Research Association.

Grossman, P. \& Stodolsky, S. (1995). Content as context: The role of school subjects in secondary teaching. Educational Researcher 24(8), 5-11.

Grouws, D. A., \& Lembke, L. O. (1996). Influential factors in student motivation to learn mathematics: The teacher and classroom culture. I M. Carr (Red.), Motivation in mathematics (s. 3962). Cresskill, USA: Hampton Press, Inc.

Hagland, K., Hedrén, R., \& Taflin, E. (2005). Rika matematiska problem - inspiration till variation. Stockholm: Liber. 
Hannula, M. S. (2006a). Affect in mathematical thinking and learning. Towards integration of emotion, motivation, and cognition. I J. Maasz \& W. Schloeglmann (Red.), New Mathematics Education Research and Practice (s. 209-232). Rotterdam, Nederländerna: Sense Publishers.

Hannula, M. S. (2006b). Motivation in mathematics: Goals reflected in emotions. Educational Studies in Mathematics, 63(2), 165178.

Hattie, J. (2009). Visible learning: A synthesis of over 800 metaanalyses relating to achievement. New York: Routledge.

Hattie, J., \& Timperley, H. (2007). The Power of Feedback. Review of Educational Research, 77(1), 81-112.

Hattie, J., Biggs, J., \& Purdie, N. (1996). Effects of learning skills interventions on student learning: A meta-analysis. Review of educational research, 66(2), 99-136.

Havnes, A., Smith, K., Dysthe, O., Ludvigsen, K. (2012). Formative assessment and feedback: Making learning visible. Studies in Educational Evaluation 38(2012), 21-27.

Hiebert, J., \& Lefevre, P. (1986). Conceptual and Procedural Knowledge in Mathematics: An Introductory Analysis. I J. Hiebert (red), Conceptual and procedural knowledge: The case of mathematics (s. 3-27). Hillsdale: Lawrence Erlbaum Associates, Inc., Publishers.

Higgins, R., Hartley, P. \& Skelton, A. (2002). The conscientious consumer: reconsidering the role of assessment feedback in student learning. Studies in Higher Education 27(1), 53-64.

Higgins, R., Hartley, P., \& Skelton, A. (2001). Getting the message across: the problem of communicating assessment feedback. Teaching in higher education, 6(2), 269-274.

Hounsell, D. (2003). Student feedback, learning and development. I M. Slowey \& D. Watson (Red.), Higher Education and the Lifecourse (s. 67-78). Buckingham: SRHE and Open University Press. 
Jablonka, E, (2011a). The (hidden) rules in a mathematics classroom. I G. Brandell \& A. Pettersson (Red.), Matematikundervisning: vetenskapliga perspektiv (s. 65-91). Stockholm: Stockholms universitets förlag.

James, D. (2000). Making the graduate: Perspectives on student experience of assessment in higher education. I A. Filer (Red.), $A s-$ sessment: Social Practice and Social Product (s. 151-167).

London \& New York: RoutledgeFalmer.

Jönsson, A. (2010). Lärande bedömning. Malmö: Gleerups.

Jönsson, A. (2012). Facilitating productive use of feedback in higher education. Active Learning in Higher Education, 14(1), 63-76.

Jönsson, A., Ekborg, M., Lindahl, B., \& Löfgren, L. (2013). Bedömning $i \mathrm{NO}$ - grundskolans tidiga år. Malmö: Gleerups.

Kamins, M. L. \& Dweck, C. S. (1999). Person Versus Process Praise and Criticism: Implications for Contingent Self-Worth and Coping. Developmental Psychology, 35(3), 835-847.

Kazemi, E., \& Stipek, D. (2001). Promoting Conceptual Thinking in Four Upper-Elementary Mathematics Classrooms. The Elementary School Journal, 102(1), 59-80.

Kjellström, K. (2005). Bedömningsmatriser - en metod för analytisk bedömning. I L. Lindström \& V. Lindberg (Red.), Pedagogisk bedömning. Om att dokumentera, bedöma och utveckla kunskap (s. 193-217). Stockholm: HLS Förlag.

Kloosterman, P. (1996). Students' Beliefs About Knowing and Learning Mathematics: Implications for Motivation. I M. Carr (Red.), Motivation in Mathematics (s. 131- 156). Cresskill: Hampton Press, Inc.

Kloosterman, P. (2002). Beliefs about mathematics and mathematics learning in the secondary school: measurement and implications for motivation. I G. C. Leder, E. Pehkonen \& G. Törner (Red.), Beliefs: A hidden variable in mathematics education (s. 247-269). Dordrecht, The Netherlands: Kluwer Academic Publishers. 
Kloosterman, P., \& Gorman, J. (1990). Building motivation in the elementary mathematics classroom. School Science and Mathematics, 90(5), 375-382

Kluger, A.N. \& DeNisi, A. (1996). The effects of feedback interventions on performance: A historical review, a meta-analysis, and a preliminary feedback intervention theory. Psychological Bulletin, 119(2), 254-284.

Kvale, S. (1997). Den kvalitativa forskningsintervjun. Lund: Studentlitteratur.

Kvale, S., \& Brinkmann, S. (2009). Den kvalitativa forskningsintervjun. Lund: Studentlitteratur.

Lee, C. (2006). Language for Learning Mathematics: Assessment for Learning in Practice. New York: Open University Press.

Lemos, M. S. (1999). Students' goals and self-regulation in the classroom. International Journal of Educational Research, 31(6), 471-485.

Lindström, L. (2005). Pedagogisk bedömning. I L. Lindström \& V. Lindberg (Red.), Pedagogisk bedömning. Om att dokumentera, bedöma och utveckla kunskap (s. 11-27). Stockholm: HLS Förlag.

Linnenbrink, E. A., \& Pintrich, P. R. (2000). Multiple Pathways to Learning and Achievement: The Role of Goal Orientation in Fostering Adaptive Motivation, Affect, and Cognition. I C. Sansone \& J. M. Harackiewicz (Red.), Intrinsic and Extrinsic Motivation. The Search for Optimal Motivation and Performance (s. 195-227). San Diego, California, USA: Academic Press.

Lipnevich, A.A. \& Smith, J.K. (2009). "I really need feedback to learn": Students' perspectives on the effectiveness of the differential feedback messages. Educational Assessment, Evaluation and Accountability 21(4), 347-367.

Lundahl, C. (2011). Bedömning för lärande. Stockholm: Norstedts. 
MacDonald, R. (1991). Developmental students' processing of teacher feedback in composition instruction. Review of Research in Developmental Education, 8(5), 1-5.

MacLellan, E. (2001). Assessment for Learning: The differing perceptions of tutors and students. Assessment \& Evaluation in Higher Education, 26(4), 307-318.

Marton, F. \& Säljö, R. (1984). Approaches to learning. I F. Marton, D. Hounsell \& N. Entwistle (Red.), The experience of learning (s. 36-55). Edinburgh: Schottish Academic Press.

Mattson, H. (1989). Proven i skolan sedda genom lärarnas ögon. Licentiatavhandling. Umeå: Umeå universitet.

Mellin-Olsen, S. (1984). Eleven, matematikken og samfunnet. En undervisningsloere. Bekkestua, Norge: NKI Forlaget.

Mellin-Olsen, S. (1987). The politics of mathematics education. Dordrecht: Kluwer Academic Publisher.

Mendick, H. (2002). "Why are we doing this?": A case study of motivational practices in mathematics class. I A. D. Cockburn \& E. Nardi (Red.), Proceedings of the $26^{\text {th }}$ Conference of the International group for the Psychology of Mathematics Education (Vol. 3, s. 329-336). Norwich: School of Education and Professional Development, University of East Anglia.

Middleton, J. A., \& Spanias, P. A. (1999). Motivation for Achievement in Mathematics: Findings, Generalizations, and Criticism of the Research. Journal for Research in Mathematics Education, 30(1), 65-88.

Nicholls, J. G. (1984). Achievement Motivation: Conceptions of Ability, Subjective Experience, Task Choice, and Performance. Psychological Review, 91(3), 328-346.

Nicol, D. J., \& MacFarlane-Dick, D. (2006). Formative assessment and self-regulated learning: a model and seven principles of good feedback practice. Studies in Higher Education, 31(2), 199-218.

Niss, M. A. (2007). Opgavediskursen i matematikundervisningen. MONA: Matematik og Naturfagsdidaktik, 2007(1), 7-17. 
Nyquist, J.B. (2003). The benefits of reconstruing feedback as a larger system of formative assessment: A meta-analysis. Opublicerad masteruppsats, Vanderbilt University, TN, USA.

Op't Eynde, P., De Corte, E., \& Verschaffel, L. (2002). Framing students' mathematics-related beliefs. I G. C. Leder, E. Pehkonen \& G. Törner (Red.), Beliefs: A hidden variable in mathematics education? (s. 13-37). Dordrecht: Kluwer Academic Publishers.

Pehkonen, E. (1998). On the concept 'mathematical belief'. I E.

Pehkonen \& G. Törner (Red.), The state-of-art in mathematics-related belief research. Results of the MAVI activities (s. 37-72). University of Helsinki. Department of Teacher Education, Research report 195.

Pehkonen, E. (2001). Lärares och elevers uppfattningar som en dold faktor i matematikundervisningen. I B. Grevholm (Red.), $M a-$ tematikdidaktik - ett nordiskt perspektiv (s. 230-256). Lund: Studentlitteratur.

Pettersson, A. (2005). Bedömning - varför, vad och varthän? I L. Lindström \& V. Lindberg (Red.), Pedagogisk bedömning. Om att dokumentera, bedöma och utveckla kunskap (s. 31-42). Stockholm: HLS Förlag.

Pimm, D. (1987). Speaking mathematically: communication in mathematics classrooms. London: Routledge \& Kegan Paul Ltd.

Pintrich, P. R. (1999). The role of motivation in promoting and sustaining self-regulated learning. International Journal of Educational Research, 31(6), 459-470.

Pintrich, P. R., \& De Groot, E. V. (1990). Motivational and SelfRegulated Learning Components of Classroom Academic Performance, Journal of Educational Psychology, 82(1), 33-40.

Pintrich, P.R. \& Schrauben, B. (1992). Students' motivational beliefs and their cognitive engagement in classroom tasks. I D.H. Schunk \& J. Meece (Red.), Student Perceptions in the Classroom: Causes and Consequences (s. 149-183). Hillsdale, NJ: Lawrence Erlbaum Associates. 
Pintrich, P.R., \& Wolters, C.A (1998). Contextual differences in student motivation and self-regulated learning in mathematics, English, and social studies classrooms. Instructional Science 26(1-2) 27-47.

Pitts, S.E. (2005). "Testing, testing." How do students use written feedback? Active Learning in Higher Education, 6(3), 218-29.

PRIM-gruppen. Bedömningsexempel Matematik kurs 1b. Hämtad 2013-12-01, från http://www.upgrades.se/wpcontent/uploads/NaP/ma_1b_ex.pdf

Rakoczy, K., Harks, B., Klieme, E., Blum, W., Hochweber, J. (2013). Written feedback in mathematics: Mediated by students' perception, moderated by goal orientation. Learning and Instruction, 27(13), 63-73.

Ramsden, P. (2003). Learning to Teach in Higher Education (2:a upplagan.). London: RoutledgeFalmer.

Resnick, L. B., Bill, V. L., Lesgold, S. B., \& Leer, M. N. (1991). Thinking in arithmetic class. I B. Means, C. Chelemer \& M. S. Knapp (Red.), Teaching advanced skills to at-risk students: Views from research and practice (s. 27-67). San Fransisco: Jossey-Bass Inc, Publishers.

Ryan, R. M., \& Deci, E. L. (2000). Self-Determination theory and the Facilitation of Intrinsic Motivation, Social Development, and Well-Being. American Psychologist, 55(1), 68- 78.

Ryan, R. M., \& Deci, E. L. (2002). Overview of Self-Determination Theory: An Organismic Dialectical Perspective. I E. L. Deci \& R. M. Ryan (Red.), Handbook of Self-Determination Research (s. 3-33). New York: The University of Rochester Press.

Sadler, R. (1989). Formative assessment and the design of instructional systems. Instructional Science, 18(2), 119-144.

Schunk, D. H., Pintrich, P. R., \& Meece, J., L. (2008). Motivation in education (3:e upplagan). Upper Saddle River, NJ: Pearson Merrill Prentice Hall. 
Sfard, A. (2000). On Reform Movement and the Limits of Mathematical Discourse. Mathematical Thinking and Learning, 2(3), 157-189.

Sfard, A. (2000). Steering (Dis)Course between Metaphors and Rigor: Using Focal Analysis to Investigate an Emergence of Mathematical Objects. Journal for Research in Mathematics Education, 31(3), 296-327.

SFS (2003:460). Lag om etikprövning av forskning som avser människor. Stockholm: Riksdagen.

Shute, V. J. (2008). Focus on formative feedback. Review of Education-al Research, 78(1), 153-189.

Sinclair, H.K., \& Cleland, J.A. (2007). Undergraduate medical students: Who seeks formative feedback? Medical Education 41(6), 580-2.

Skolinspektionen (2009). Kvalitetsgranskning. Rapport 2009:5. Undervisningen i matematik: undervisningens innehåll och ändamålsenlighet. Stockholm: Skolinspektionen.

Skolverket. (2002). Gymnasieskolans kursprov vårterminen 2002. Stockholm: Skolverket.

Skolverket. (2003). Lusten att lära-med fokus på matematik: Nationella kvalitetsgranskningar 2001-2002. Stockholm: Skolverket.

Skolverket. (2011). Läroplan, examensmål och gymnasiegemensamma ämnen för gymnasieskola. Stockholm: Skolverket.

Steinbring, H. (1998). Elements of epistemological knowledge for mathematics teachers. Journal of Mathematics Teacher Education, 1(2), 157-189.

Stevenson, H.W. \& Stigler, J.W. (1992). The learning gap: Why our schools are failing and what we can learn from Japanese and Chinese education. New York: Summit Books.

Stipek, D. J. (1996). Motivation and instruction. I D. C. Berliner \& R. C. Calfee (Red.), Handbook of educational psychology (s. 85 113). New York: Simon \& Schuster Macmillan. 
Stipek, D., Salmon, J. M., Givvin, K. B., \& Kazemi, E. (1998). The Value (and Convergence) of Practices Suggested by Motivation Research and Promoted by Mathematics Education Reformers. Journal for Research in Mathematics Education, 29(4), 465- 488.

Stodolsky, S. \& Grossman, P. (1995). The impact of subject matter on curricular activity: An analysis of five academic subjects. American Educational Research Journal 32, 227-249.

Stodolsky, S. (1988). The Subject Matters: Classroom Activity in Math and Social Studies. Chicago: The University of Chicago Press.

Tytler, R., Osborne, J., Williams, G., Tytler, K., \& Cripps Clarke, J. (2008). Opening up pathways: Engagement in STEM across the Primary-Secondary school transition.

Waege, K. (2007). Elevenes motivasjon for å loere matematikk og undersøkende matematikkundervisning. Doktorsavhandling, Trondheim: NTNU.

Wedege, T., \& Skott, J. (2007). Potential for Change of Views in the Mathematics Classroom? I D. Pitta-Pantazi \& G. Philippou (Red.), Proceedings of the Fifth Congress of the European Society for Research in Mathematics Education (CERME5), Cypern, 22-26 February, 2007.

Wedege, T., Skott, J., Henningsen, I., \& Waege, K. (2006). Changing views and practices? A study of the KappAbel mathematics competition. Norwegian Center for Mathematics Education, NTNU.

Wigfield, A. \& Eccles, J.S. (1992). The development of achievement task values: A theoretical analyses. Developmental Review $12(3), 265-310$.

Wigfield, A. \& Eccles, J.S. (1994). Children's competence beliefs, achievement values, and general self-esteem change across elementary and middle school. Journal of Early Adolescence 14(2), 107-138. 
Wigfield, A. (1994). Expectancy-value theory of achievement motivation: A developmental perspective. Educational Psychology Review 6(1), 49-77.

Wigfield, A., \& Eccles, J. S. (2000). Expectancy-value theory of achievement motivation. Contemporary educational psychology, 25(1), 68-81.

Wiliam, D. (2010). An integrative summary of the research literature and implications for a new theory of formative assessment. I H.A. Andrade \& G. J.Cizek (Red.), Handbook of formative assessment (s.18-40). New York \& London: Routledge.

Wiliam, D. (2011). What is assessment for learning? Studies in Educational Evaluation, 37(2011), 3-14.

Winne, P.H. (1996). Metacognitive view of individual differences in self-regulated learning. Learning and Individual Differences, $8(4), 327-353$.

Yackel, E. (2000). Creating a Mathemtics Classroom Environment that Fosters the Development of Mathematical Argumentation. Ninth International Congress of Mathematical Education. Tokyo/Makuhari, Japan:

http://www.nku.edu/ sheffield/eyackel.html.

Yackel, E., \& Cobb, P. (1996). Sociomathematical norms, argumentation and autonomy in Mathematics. Journal for Research in Mathematics Education, 27(4), 458-477.

Yates, S. M. (2000). Student optimism, pessimism, motivation and achievement in mathematics: A longitudinal study. I T. Nakahara \& M. Koyama (Red.), Proceedings of the 24th Conference of the International Group for the Psychology of Mathematics Education (Vol. 4, s. 297-304). Japan: Hiroshima University.

Yorke, M. (2003). Formative assessment in higher education: Moves towards theory and the enhancement of pedagogic practice. Higher education, 45(4), 477-501.

Zimmerman, B.J. (2002). Becoming a Self-Regulated Learner: An Overview. Theory into practice 41(2), 64-70. 
Österholm, M. (2006). Kognitiva och metakognitiva perspektiv på läsförståelse inom matematik. Doktorsavhandling, Linköping: Linköpings universitet. 


\section{Bilagor}

I bilagorna redovisas fyra elevers återkopplingar. En bilaga ges för varje elev och redovisar två exempel på återkoppling per elev.

\section{Bilaga 1}

\section{Exempel 1}

- Vi har tittat på om ni kan säga ngt om deras löner från början:

De har inte samma lön från början. Lisa har högre lön eftersom hon får mindre ökning. Andreas har fătt större ökning, dvs. han hade mindre lön från början.

- Om ni kan ge ngt räkneexempel på detta:

Låt oss anta att Lisa från början hade $200 \mathrm{kr}$ i timlön och Andreas hade $100 \mathrm{kr}$. När Lisas lön höjs med 2,5\% (0,025 · 200) höjd den med $5 \mathrm{kr}$. Andreas lön höjs med $5 \%(0,05 \cdot 100)$ alltså $5 \mathrm{kr}$. Bägges löner höjs lika mycket eftersom Lisa från början fick dubbelt så mycket $\mathrm{i}$ lön jämfört med Andreas.

- Om ni kan ge en mera generell lösning på problemet:

Lisas gamla lön: $\mathrm{x} \mathrm{kr}$, Lisas löneökning: $0,025 \cdot \mathrm{x}$ kr.

Andreas gamla lön: y kr, Andreas löneökning: 0,05 · y kr.

Om lönehöjningen är lika är $0,025 \cdot \mathrm{x} \mathrm{kr}=0,05 \cdot \mathrm{y} \mathrm{kr} ; \mathrm{x}=2 \mathrm{y}$, dvs. Lisas lön är dubbelt så stor som Andreas från början.

: Du har fixat de två ovan första punkterna! Dock tycker vi du ska titta på den tredje punkten som visar en generell lösningsmetod som skulle tagit dig högre i kunskapsnivå. Hur känns den? 


\section{Exempel 2}

Om det är något som ni inte förstår med återkopplingen (vilket vi förmodar är fallet(:)) på era testuppgifter ber vi er att fråga oss! /Jenny och .......

\begin{tabular}{|c|c|c|}
\hline Namn & \\
\hline 8.a.) & \multicolumn{2}{|c|}{$\begin{array}{l}\text { Digitaltryckeriet: } 44 \text { kr och } 140 \text { kr; Tryckservice: } 36 \text { kr } \\
\text { och } 180 \text { kr } \\
\text { Korrekt ifylld tabell. }\end{array}$} \\
\hline b.) & \multicolumn{2}{|c|}{$\begin{array}{l}\text { Du har ställt upp korrekt ekvation, utan att du löst den. Kolla } \\
\text { på detta lösningsförslag: } \\
\mathrm{y}=\text { kostnad, } \mathrm{x}=\text { antal ex } \\
\mathrm{y}=20 \mathrm{kr}+24 \text { öre } \mathrm{x} \\
320=20+0,24 \mathrm{x} \\
\begin{array}{l}300=0,24 \mathrm{x} \\
\mathrm{y}=1250 \mathrm{st}\end{array}\end{array}$} \\
\hline c.) & \multicolumn{2}{|c|}{$\begin{array}{l}\text { K(x) }=\mathbf{2 0}+\mathbf{0 , 2 4 x} \\
\text { Inget svar. Har du ingen aning om hur du ska börja? Det är } \\
\text { okej att prova utan att veta. Kolla ovan formel. Hur känns } \\
\text { den? Kan du följa den? K(x) står för kostnad av x st reklam- } \\
\text { blad hos Digitaltryckeriet. }\end{array}$} \\
\hline d.) & \multicolumn{2}{|c|}{$\begin{array}{l}\mathbf{1 6 7} \text { blad } \\
\text { Se lösningsförslag för hur den elev (tidigare NP) sist i doku- } \\
\text { mentet har gjort. Vi ger tre lösningsförslag, prövning, ekvat- } \\
\text { ion och grafisk. Kolla efter och se vad som känns bäst för dig } \\
\text { att göra. }\end{array}$} \\
\hline \multicolumn{2}{|c|}{ Styrkor } & \\
\hline \multicolumn{2}{|c|}{ Utvecklingsbehov } & \\
\hline
\end{tabular}




\begin{tabular}{|l|l|}
\hline & $\begin{array}{l}\text { hetstecknet va? Koncentrera dig sedan på den } \\
\text { variabel (x, y el annat) som du vill få fri. Vad } \\
\text { behöver jag lägga till, ta bort mm för att få denna } \\
\text { variabel fri? }\end{array}$ \\
$\begin{array}{l}\text { Du behöver även arbeta vidare med grafer. Du } \\
\text { behöver kunna rita upp dem. Kolla lösningsför- } \\
\text { slaget som sagt. }\end{array}$ \\
\hline
\end{tabular}

\begin{tabular}{|l|l|}
\hline Vad vi tycker du & Efter att du läst igenom kommentarerna är första \\
bör göra efter att & frågan vi tycker du ska ställa dig frågan om du \\
du fătt denna & förstått det vi skrivit. Vi tycker att du ska jämföra \\
återkoppling: & dina svar med lösningsförslagen och sedan tycker \\
& $\begin{array}{l}\text { vi att du ska göra om uppgifterna igen. Vi tycker } \\
\text { givetvis att du ska återkomma till oss om det är } \\
\text { några problem! }\end{array}$ \\
\hline
\end{tabular}




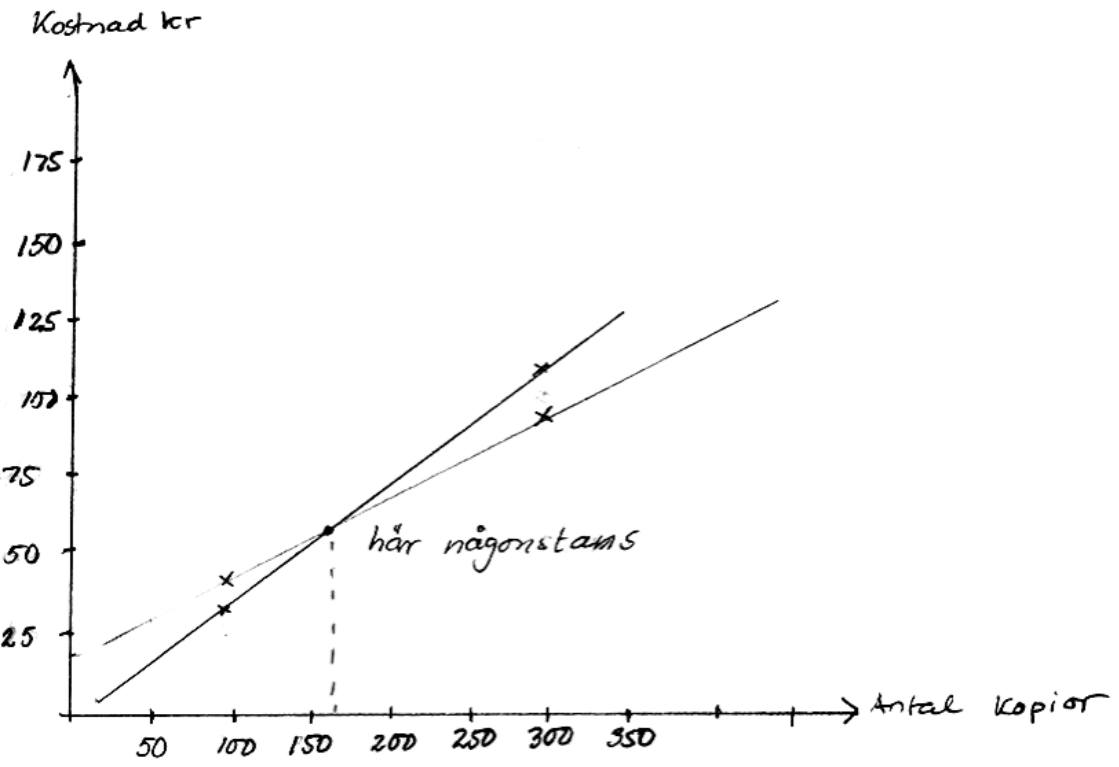

$100 \mathrm{kop}$. hos Digitalt. $20+0,24 \cdot 100 \mathrm{kr}=44 \mathrm{kr}$

$300 \mathrm{kop}$ hos - u $20+0,24 \cdot 300 \mathrm{kr}=92 \mathrm{kr}$

$\begin{array}{ll}100 \mathrm{kop} \text { hrs Tryck } A B & 100 \cdot 0,36 \mathrm{kr}=36 \mathrm{kr} \\ 300 \mathrm{kp} & 300 \cdot 0,36 \mathrm{kr}=108 \mathrm{kr}\end{array}$

Srar: Ca 170 kopior 
Fler añ 100 tryck!!

250st Digitaltryckeriet: $250.0,24 \mathrm{kr}+20 \mathrm{kr}=80 \mathrm{kr}$ Tryckservice $A B: 0,36 \cdot 500 \mathrm{kr}=180 \mathrm{kr}$

20057

$$
\begin{aligned}
& D . t=68 \mathrm{kr} \\
& T A B=72 \mathrm{kr} \\
& D t=60,8 \mathrm{kr} \\
& T A B=61,2 \mathrm{kr}
\end{aligned}
$$

170 st

Srar: Ca 170 tryck

$x=$ antalet blad díkostriaded är lika

$$
\begin{aligned}
20+0,24 x & =0,36 x \\
20 & =0,12 x \\
\frac{20}{0,12} & =x \\
x & \approx 167
\end{aligned}
$$

Srar: Da' antalet kopior ä 167 eller fler.

141 


\section{Bilaga 2}

\section{Exempel 1}

- Vi har tittat på om ni kan säga ngt om deras löner från början:

De har inte samma lön från början. Lisa har högre lön eftersom hon får mindre ökning. Andreas har fătt större ökning, dvs. han hade mindre lön från början.

- Om ni kan ge ngt räkneexempel på detta:

Låt oss anta att Lisa från början hade $200 \mathrm{kr}$ i timlön och Andreas hade $100 \mathrm{kr}$. När Lisas lön höjs med 2,5 \% (0,025 · 200) höjd den med $5 \mathrm{kr}$. Andreas lön höjs med $5 \%(0,05 \cdot 100)$ alltså $5 \mathrm{kr}$. Bägges löner höjs lika mycket eftersom Lisa från början fick dubbelt så mycket $\mathrm{i}$ lön jämfört med Andreas.

- Om ni kan ge en mera generell lösning på problemet:

Lisas gamla lön: $\mathrm{x}$ kr, Lisas löneökning: $0,025 \cdot \mathrm{x}$ kr.

Andreas gamla lön: y kr, Andreas löneökning: $0,05 \cdot \mathrm{y} \mathrm{kr}$.

Om lönehöjningen är lika är $0,025 \cdot \mathrm{x} \mathrm{kr}=0,05 \cdot \mathrm{y} \mathrm{kr}$; $\mathrm{x}=2 \mathrm{y}$, dvs. Lisas lön är dubbelt så stor som Andreas från början.

: Det är svårt att följa dina beräkningar! Du måste titta på förändringsfaktorn en gång till. En ökning med $5 \%$ t.ex. ger förändringsfaktorn 1,05, inte 1,5. I princip har du klarat de två översta punkterna. Skriver i princip eftersom din redovisning inte är helt korrekt. 


\section{Exempel 2}

Om det är något som ni inte förstår med återkopplingen (vilket vi förmodar är fallet(:) på era testuppgifter ber vi er att fråga oss!

/Jenny och .......

\begin{tabular}{|c|c|c|}
\hline \multicolumn{3}{|l|}{ Namn } \\
\hline 8.a.) & \multicolumn{2}{|c|}{$\begin{array}{l}\text { Digitaltryckeriet: } 44 \text { kr och } 140 \text { kr; Tryckservice: } 36 \text { kr } \\
\text { och } 180 \text { kr } \\
\text { Fel angivna svar. (Lösningsförslag för } 100 \text { st kopior - se om } \\
\text { du kan räkna för } 500 \text { kopior själv) } \\
\text { Kostnad Digitaltryckeriet }=20 \mathrm{kr}+0,24 \mathrm{kr} \cdot 100=44 \mathrm{kr} \\
\text { Kostnad Tryckeriservice } \mathrm{AB}=0,36 \mathrm{kr} \cdot 100=36 \mathrm{kr}\end{array}$} \\
\hline b.) & \multicolumn{2}{|c|}{$\begin{array}{l}\text { Bristfällig redovisning. Jag kan inte ge dig någon återkopp- } \\
\text { ling på det som du gjort eftersom jag inte kan följa hur du } \\
\text { tänkt. Skriv vad det är du räknar ut! Ett annat förslag på hur } \\
\text { du kunnat göra: } \\
y=\text { kostnad, } x=\text { antal ex } \\
y=20 \mathrm{kr}+24 \text { öre } x \\
\begin{array}{l}320=20+0,24 x \\
300=0,24 x \\
y=1250 \mathrm{st}\end{array}\end{array}$} \\
\hline c.) & \multicolumn{2}{|c|}{$\begin{array}{l}\mathbf{K}(\mathbf{x})=\mathbf{2 0}+\mathbf{0 , 2 4 x} \\
\text { Godtagbar formel, men ange gärna vad dina variabler står för } \\
(\text { dvs. k och } \mathrm{x}) \text {. }\end{array}$} \\
\hline d.) & \multicolumn{2}{|c|}{$\begin{array}{l}167 \text { blad } \\
\text { Fel angivet svar. Se lösningsförslag för elev (tidigare NP) sist } \\
\text { i dokumentet. Prövning, ekvation och grafisk lösning. }\end{array}$} \\
\hline \multicolumn{2}{|c|}{ Styrkor } & \\
\hline & & \\
\hline
\end{tabular}




\begin{tabular}{|l|l|}
\hline $\begin{array}{l}\text { ter. Svårt för oss som lärare att ge dig återkopp- } \\
\text { ling på det som du gjort när du inte skriver hur } \\
\text { du tänker. Vi tror även att det framöver kommer } \\
\text { bli lättare för dig att nå en högre kunskapsnivå } \\
\text { om du redovisar dina uppgifter, det gör det alltså } \\
\text { inte bara lättare för din lärare att följa dig utan } \\
\text { framför allt för dig själv! }\end{array}$ \\
$\begin{array}{l}\text { Hur känner du det med ekvationer? Du vet att du } \\
\text { får göra "precis" vad du vill med en ekvation så } \\
\text { länge du gör samma sak på båda sidor om lik- } \\
\text { hetstecknet va? Koncentrera dig sedan på den } \\
\text { variabel (x, y el annat) som du vill få fri. Vad } \\
\text { behöver jag lägga till, ta bort mm för att få denna } \\
\text { variabel fri? } \\
\text { Hur har du det med grafer? Du måste kunna rita } \\
\text { upp grafer. Se lösningsförslaget. }\end{array}$ \\
\hline
\end{tabular}

\begin{tabular}{|l|l|}
\hline Vad vi tycker du & Efter att du läst igenom kommentarerna är första \\
bör göra efter att & frågan vi tycker du ska ställa dig frågan om du \\
du fått denna & förstått det vi skrivit. Vi tycker att du ska jämföra \\
återkoppling: & dina svar med lösningsförslagen. Vidare tycker vi \\
& $\begin{array}{l}\text { att du ska göra uppgifterna igen. Vi tycker givetvis } \\
\text { att du ska återkomma till oss om det är några pro- } \\
\text { blem! }\end{array}$ \\
\hline
\end{tabular}




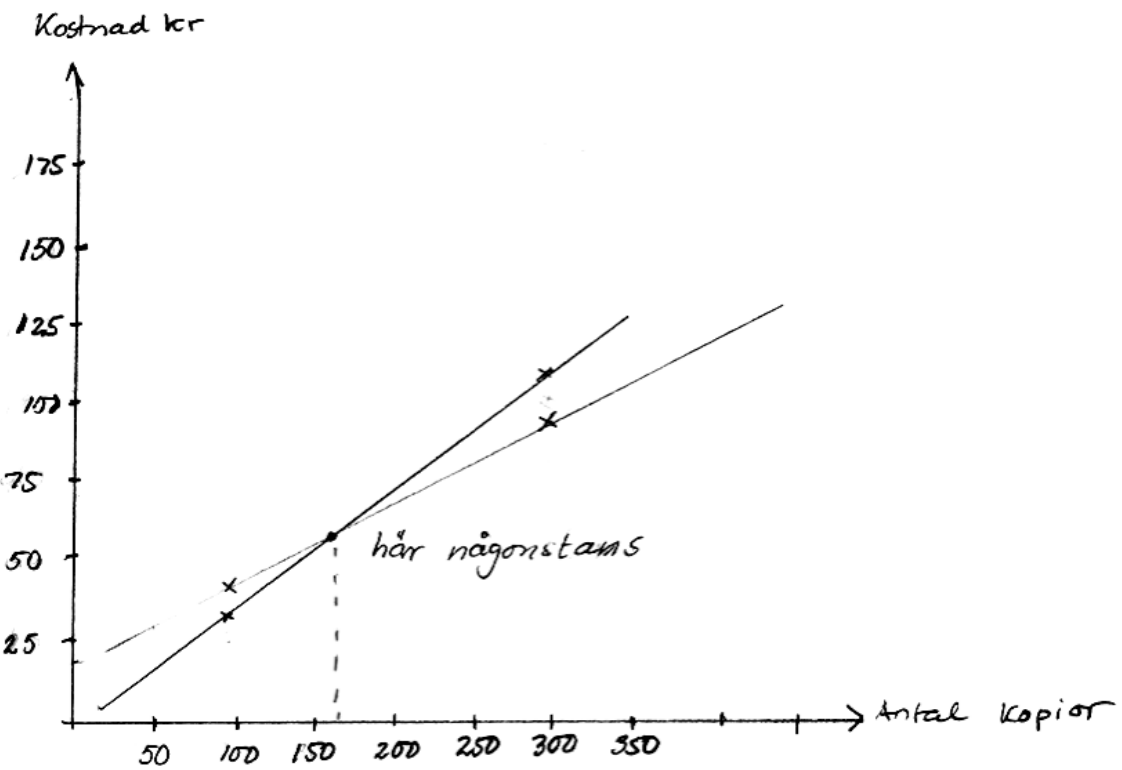

$100 \mathrm{kop}$. hos Digitalt. $20+0,24.100 \mathrm{kr}=44 \mathrm{kr}$

$300 \mathrm{kop}$ hos - u $\quad 20+0,24 \cdot 300 \mathrm{kr}=92 \mathrm{kr}$

$\begin{array}{ll}100 \mathrm{kop} \text { hos Tryck AB } & 100 \cdot 0,36 \mathrm{kr}=36 \mathrm{kr} \\ 300 \mathrm{kp} \text { hos } & 300 \cdot 0,36 \mathrm{kr}=108 \mathrm{kr}\end{array}$

Srar: Ca 170 kopior 
Fler añ 100 tryck!!

250st Digitaltryckeriet: $250 \cdot 0,24 \mathrm{kr}+20 \mathrm{kr}=80 \mathrm{kr}$ Tryckservice $A B: 0,36 \cdot 500 \mathrm{kr}=180 \mathrm{kr}$

20057

$$
\text { 200SA) } \begin{aligned}
D . t & =68 \mathrm{kr} \\
T A B & =72 \mathrm{kr} \\
\text { (170 st } D t & =60,8 \mathrm{kr} \\
T A B & =61,2 \mathrm{kr}
\end{aligned}
$$

Srar: ca 170 tryck

$x=$ antalet blad däkosmaden är lika

$$
\begin{aligned}
20+0,24 x & =0,36 x \\
20 & =0,12 x \\
\frac{20}{0,12} & =x \\
x & \approx 167
\end{aligned}
$$

Srar: Dä antalet kopior ä 167 eller fler.

146 


\section{Bilaga 3}

\section{Exempel 1}

- Vi har tittat på om ni kan säga ngt om deras löner från början:

De har inte samma lön från början. Lisa har högre lön eftersom hon får mindre ökning. Andreas har fått större ökning, dvs. han hade mindre lön från början.

- Om ni kan ge ngt räkneexempel på detta:

Låt oss anta att Lisa från början hade $200 \mathrm{kr}$ i timlön och Andreas hade $100 \mathrm{kr}$. När Lisas lön höjs med 2,5\% (0,025 · 200) höjd den med $5 \mathrm{kr}$. Andreas lön höjs med $5 \%(0,05 \cdot 100)$ alltså $5 \mathrm{kr}$. Bägges löner höjs lika mycket eftersom Lisa från början fick dubbelt så mycket $\mathrm{i}$ lön jämfört med Andreas.

- Om ni kan ge en mera generell lösning på problemet:

Lisas gamla lön: $\mathrm{x} \mathrm{kr}$, Lisas löneökning: $0,025 \cdot \mathrm{x} \mathrm{kr}$. Andreas gamla lön: y kr, Andreas löneökning: $0,05 \cdot \mathrm{y}$ kr.

Om lönehöjningen är lika är $0,025 \cdot \mathrm{x} \mathrm{kr}=0,05 \cdot \mathrm{y} \mathrm{kr} ; \mathrm{x}=2 \mathrm{y}$, dvs. Lisas lön är dubbelt så stor som Andreas från början.

: Du har fixat ovan två första punkter. Titta på den tredje punkten som visar en generell lösningsmetod. Du är på väg på den. Fundera en gång till på din förklaring $20 \mathrm{x}=20 \mathrm{x}$, det är ju rimligt, men förklarar det detta samband? Hur känns $\mathrm{x}=2$ y som i tredje punkten? Du redovisar på ett bra sätt, tydligt och du anger vad det är du beräknar. 


\section{Exempel 2}

Om det är något som ni inte förstår med återkopplingen (vilket vi förmodar är fallet(:) på era testuppgifter ber vi er att fråga oss!

/Jenny och .......

\begin{tabular}{|c|c|}
\hline & \\
\hline 8.a.) & $\begin{array}{l}\text { Digitaltryckeriet: } 44 \text { kr och } 140 \text { kr; Tryckservice: } 36 \text { kr } \\
\text { och } 180 \text { kr } \\
\text { Korrekt ifylld tabell. }\end{array}$ \\
\hline b.) & $\begin{array}{l}1250 \text { st. } \\
\text { Du tecknar division och anger rätt svar. Dock saknar vi en } \\
\text { tydligare redovisning. Du anger uträkningen, men inte vad det } \\
\text { är du räknar ut. Detta kommer att hjälpa dig vid svårare upp- } \\
\text { gifter. } \\
\text { Kolla detta lösningsförslag, hur känns det? } \\
y=\text { kostnad, } x=\text { antal ex } \\
y=20 \mathrm{kr}+24 \text { öre } x \\
320=20+0,24 x \\
300=0,24 x \\
y=1250 \mathrm{st}\end{array}$ \\
\hline c.) & $\begin{array}{l}\mathbf{K}(\mathbf{x})=\mathbf{2 0}+\mathbf{0 , 2 4 x} \\
\text { Du har i princip uttrycket, men vi vill gärna se hela ovan ut- } \\
\text { tryck. Ange vad dina "obekanta", dvs. variablerna står för. } \\
\text { Tycker att det varit ok att skriva y istället för K(x). }\end{array}$ \\
\hline d.) & $\begin{array}{l}167 \text { blad } \\
\text { Godtagbart svar. Du använder dig av prövning, tror dock att } \\
\text { du skulle kunnat fixa generell lösningsmetod, dvs. genom en } \\
\text { ekvation t.ex. Det hade gått fortare och tagit dig till en högre } \\
\text { kunskapsnivå. Kolla lösningsförslag för hur den elev (tidigare } \\
\text { NP) sist i dokumentet har gjort. De två lösningsförslagen vi- } \\
\text { sar lösning med hjälp av ekvation och grafiskt. }\end{array}$ \\
\hline & \\
\hline
\end{tabular}




\begin{tabular}{|l|l|}
\hline & band. Du visar förmåga på att lösa ekvationer. \\
\hline Utvecklingsbehov & $\begin{array}{l}\text { Du behöver titta på grafiska lösningar. Du måste } \\
\text { kunna rita upp grafer. Du behöver även titta vi- } \\
\text { dare på ekvation som generell metod (som i } \\
\text { uppg d t.ex.). }\end{array}$ \\
\hline
\end{tabular}

\begin{tabular}{|l|l|}
\hline Vad vi tycker du & Efter att du läst igenom kommentarerna är första \\
bör göra efter att & frågan vi tycker du ska ställa dig frågan om du \\
du fătt denna & förstått det vi skrivit. Vi tycker att du ska jämföra \\
återkoppling: & $\begin{array}{l}\text { dina svar med lösningsförslagen och sedan tycker } \\
\text { vi att du ska göra om de uppgifter som vi kom- } \\
\text { menterat. }\end{array}$ \\
\hline
\end{tabular}




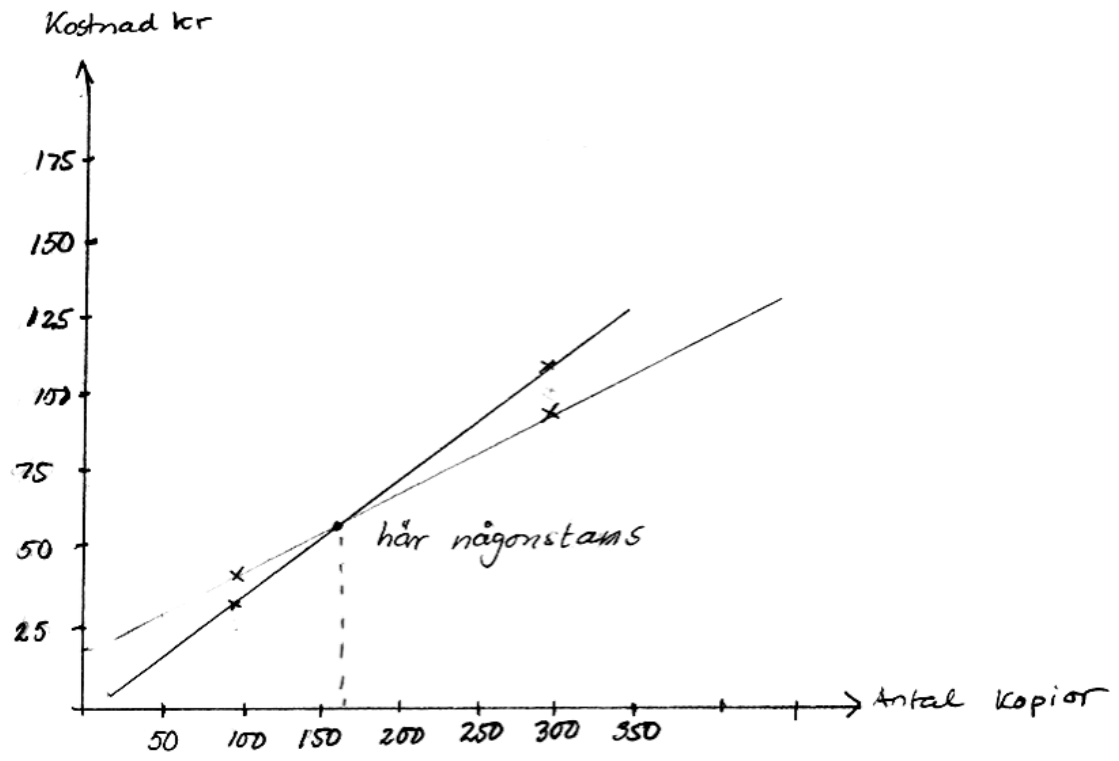

$\begin{array}{ll}100 \mathrm{kop} . \text { hos Digitalt. } & 20+0,24 \cdot 100 \mathrm{kr}=44 \mathrm{kr} \\ 300 \mathrm{kop} \text { hos }-4- & 20+0,24 \cdot 300 \mathrm{kr}=92 \mathrm{kr} \\ 100 \mathrm{kop} \text { hos Tryck AB } & 100 \cdot 0,36 \mathrm{kr}=36 \mathrm{kr} \\ 300 \mathrm{kp} \text { hos } & 300 \cdot 0,36 \mathrm{kr}=108 \mathrm{kr}\end{array}$

Srar: Ca 170 kopior

$$
\begin{gathered}
x=\text { antalet blad di kostraded ä lika } \\
\begin{aligned}
20+0,24 x & =0,36 x \\
20 & =0,12 x \\
\frac{20}{0,12} & =x \\
x & \approx 167
\end{aligned}
\end{gathered}
$$

Srar: Dä antalet kopior ä 167 eller fler. 
Studies in Science and Technology Education

ISSN 1652-5051

\section{rontP}

1. Margareta Enghag (2004): MINIPROJECTS AND CONTEXT RICH PROBLEMS - Case studies with qualitative analysis of motivation, learner ownership and competence in small group work in physics. (licentiate thesis) Linköping University

2. Carl-Johan Rundgren (2006): Meaning-Making in Molecular Life Science Education - upper secondary school students' interpretation of visualizations of proteins. (licentiate thesis) Linköping University

3. Michal Drechsler (2005): Textbooks', teachers', and students' understanding of models used to explain acid-base reactions. ISSN: 1403-8099, ISBN: 91-85335-40-1. (licentiate thesis) Karlstad University

4. Margareta Enghag (2007): Two dimensions of Student Ownership of Learning during Small-Group Work with Miniprojects and context rich Problems in Physics. ISSN: 1651-4238, ISBN: 91-85485-31-4. (Doctoral Dissertation) Mälardalen University

5. Maria Åström (2007): Integrated and Subject-specific. An empirical exploration of Science education in Swedish compulsory schools. (Licentiate thesis) Linköping university

6. Ola Magntorn (2007): Reading Nature: developing ecological literacy through teaching. (Doctoral Dissertation) Linköping University

7. Maria Andreé (2007): Den levda läroplanen. En studie av naturorienterande undervisningspraktiker i grundskolan. ISSN: 1400-478X, HLS Förlag: ISBN 978-91-7656-632-9 (Doctoral Dissertation, LHS)

8. Mattias Lundin (2007): Students' participation in the realization of school science activities.(Doctoral Dissertation) Linköping University

9. Michal Drechsler (2007): Models in chemistry education. A study of teaching and learning acids and bases in Swedish upper secondary schools ISBN 978-91-7063-112-2 (Doctoral Dissertation) Karlstad University 
Studies in Science and Technology Education

ISSN 1652-5051

\section{rontP}

10. Proceedings from FontD Vadstena-meeting, April 2006.

11. Eva Blomdahl (2007): Teknik i skolan. En studie av teknikundervisning för yngre skolbarn. ISSN: 1400-478X, HLS Förlag: ISBN 978-91-7656-635-0 (Doctoral Dissertation, LHS)

12. Iann Lundegård (2007): På väg mot pluralism. Elever i situerade samtal kring hållbar utveckling. ISSN:1400-478X, HLS Förlag: ISBN 978-91-7656-642-8 (Doctoral Dissertation, LHS)

13. Lena Hansson (2007): "Enligt fysiken eller enligt mig själv?" - Gymnasieelever, fysiken och grundantaganden om världen. (Doctoral Dissertation) Linköping University.

14. Christel Persson (2008): Sfärernas symfoni i förändring? Lärande i miljö för hållbar utveckling med naturvetenskaplig utgångspunkt. En longitudinell studie i grundskolans tidigare årskurser. (Doctoral Dissertation) Linköping University

15. Eva Davidsson (2008): Different Images of Science - a study of how science is constituted in exhibitions. ISBN: 978-91977100-1-5 (Doctoral Dissertation) Malmö University

16. Magnus Hultén (2008): Naturens kanon. Formering och förändring av innehållet i folkskolans och grundskolans naturvetenskap 1842-2007. ISBN: 978-91-7155-612-7 (Doctoral Dissertation) Stockholm University

17. Lars-Erik Björklund (2008): Från Novis till Expert: Förtrogenhetskunskap i kognitiv och didaktisk belysning. (Doctoral Dissertation) Linköping University.

18. Anders Jönsson (2008): Educative assessment for/of teacher competency. A study of assessment and learning in the "Interactive examination" for student teachers. ISBN: 978-91977100-3-9 (Doctoral Dissertation) Malmö University

19. Pernilla Nilsson (2008): Learning to teach and teaching to learn - primary science student teachers' complex journey from learners to teachers. (Doctoral Dissertation) Linköping University 
Studies in Science and Technology Education

ISSN 1652-5051

FontD

20. Carl-Johan Rundgren (2008): VISUAL THINKING, VISUAL SPEECH - a Semiotic Perspective on Meaning-Making in Mlecular Life Science. (Doctoral Dissertation) Linköping University

21. Per Sund (2008): Att urskilja selektiva traditioner i miljöundervisningens socialisationsinnehåll - implikationer för undervisning för hållbar utveckling. ISBN: 978-91-85485-88-8

(Doctoral Dissertation) Mälardalen University

22. Susanne Engström (2008): Fysiken spelar roll! I undervisning om hållbara energisystem - fokus på gymnasiekursen Fysik A. ISBN: 978-91-85485-96-3 (Licentiate thesis) Mälardalen University

23. Britt Jakobsson (2008): Learning science through aesthetic experience in elementary school science. Aesthetic judgement, metaphor and art. ISBN: 978-91-7155-654-7. (Doctoral Dissertation) Stockholm university

24. Gunilla Gunnarsson (2008): Den laborativa klassrumsverksamhetens interaktioner - En studie om vilket meningsskapande år 7-elever kan erbjudas i möten med den laborativa verksamhetens instruktioner, artefakter och språk inom elementär ellära, samt om lärares didaktiska handlingsmönster i dessa möten. (Doctoral Dissertation) Linköping University

25. Pernilla Granklint Enochson (2008): Elevernas föreställningar om kroppens organ och kroppens hälsa utifrån ett skolsammanhang. (Licentiate thesis) Linköping University

26. Maria Åström (2008): Defining Integrated Science Education and putting it to test (Doctoral Dissertation) Linköping University

27. Niklas Gericke (2009): Science versus School-science. Multiple models in genetics - The depiction of gene function in upper secondary textbooks and its influence on students' understanding. ISBN 978-91-7063-205-1 (Doctoral Dissertation) Karlstad University 
Studies in Science and Technology Education

ISSN 1652-5051

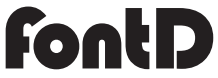

28. Per Högström (2009): Laborativt arbete i grundskolans senare år - lärares mål och hur de implementeras. ISBN 978-91-7264755-8 (Doctoral Dissertation) Umeå University

29. Annette Johnsson (2009): Dialogues on the Net. Power structures in asynchronous discussions in the context of a web based teacher training course. ISBN 978-91-977100-9-1 (Doctoral Dissertation) Malmö University

30. Elisabet M. Nilsson (2010): Simulated "real" worlds: Actions mediated through computer game play in science education. ISBN 978-91-86295-02-8 (Doctoral Dissertation) Malmö University

31. Lise-Lotte Österlund (2010): Redox models in chemistry: A depiction of the conceptions held by upper secondary school students of redox reactions. ISBN 978-91-7459-053-1 (Doctoral Dissertation) Umeå University

32. Claes Klasander (2010): Talet om tekniska system - förväntningar, traditioner och skolverkligheter. ISBN 978-91-7393332-2 (Doctoral Dissertation) Linköping University

33. Maria Svensson (2011): Att urskilja tekniska system - didaktiska dimensioner i grundskolan. ISBN 978-91-7393-250-9 (Doctoral Dissertation) Linköping University

34. Nina Christenson (2011): Knowledge, Value and Personal experience - Upper secondary students' use of supporting reasons when arguing socioscientific issues. ISBN 978-91-7063340-9 (Licentiate thesis) Karlstad University

35. Tor Nilsson (2011): Kemistudenters föreställningar om entalpi och relaterade begrepp. ISBN 978-91-7485-002-4 (Doctoral Dissertation) Mälardalen University

36. Kristina Andersson (2011): Lärare för förändring - att synliggöra och utmana föreställningar om naturvetenskap och genus. ISBN 978-91-7393-222-6 (Doctoral Dissertation) Linköping University 
Studies in Science and Technology Education

ISSN 1652-5051

PontD

37. Peter Frejd (2011): Mathematical modelling in upper secondary school in Sweden An exploratory study. ISBN: 978-917393-223-3 (Licentiate thesis) Linköping University

38. Daniel Dufåker (2011): Spectroscopy studies of few particle effects in pyramidal quantum dots. ISBN 978-91-7393-179-3 (Licentiate thesis) Linköping University

39. Auli Arvola Orlander (2011): Med kroppen som insats: Diskursiva spänningsfält i biologiundervisningen på högstadiet. ISBN 978-91-7447-258-5 (Doctoral Dissertation) Stockholm University

40. Karin Stolpe (2011): Att uppmärksamma det väsentliga. Lärares ämnesdidaktiska förmågor ur ett interaktionskognitivt perspektiv. ISBN 978-91-7393-169-4 (Doctoral Dissertation) Linköping University

41. Anna-Karin Westman (2011) Samtal om begreppskartor - en väg till ökad förståelse. ISBN 978-91-86694-43-2 (Licentiate thesis) Mid Sweden University

42. Susanne Engström (2011) Att vördsamt värdesätta eller tryggt trotsa. Gymnasiefysiken, undervisningstraditioner och fysiklärares olika strategier för energiundervisning. ISBN 978-917485-011-6 (Doctoral Dissertation) Mälardalen University

43. Lena Adolfsson (2011) Attityder till naturvetenskap. Förändringar av flickors och pojkars attityder till biologi, fysik och kemi 1995 till 2007. ISBN 978-91-7459-233-7 (Licentiate thesis) Umeå University

44. Anna Lundberg (2011) Proportionalitetsbegreppet i den svenska gymnasie-matematiken - en studie om läromedel och nationella prov. ISBN 978-91-7393-132-8 (Licentiate thesis) Linköping University 
Studies in Science and Technology Education

ISSN 1652-5051

\section{rontP}

45. Sanela Mehanovic (2011) The potential and challenges of the use of dynamic software in upper secondary Mathematics. Students' and teachers' work with integrals in GeoGebra based environments. ISBN 978-91-7393-127-4 (Licentiate thesis) Linköping University

46. Semir Becevic (2011) Klassrumsbedömning i matematik på gymnasieskolans nivå. ISBN 978-91-7393-091-8 (Licentiate thesis) Linköping University

47. Veronica Flodin (2011) Epistemisk drift - genbegreppets variationer i några av forskningens och undervisningens texter $\mathrm{i}$ biologi. ISBN 978-91-9795-161-6 (Licentiate thesis) Stockholm University

48. Carola Borg (2011) Utbildning för hållbar utveckling ur ett lärarperspektiv - Ämnesbundna skillnader i gymnasieskolan. ISBN 978-91-7063-377-5 (Licentiate thesis) Karlstad University

49. Mats Lundström (2011) Decision-making in health issues: Teenagers' use of science and other discourses. ISBN 978-9186295-15-8 (Doctoral Dissertation) Malmö University

50. Magnus Oscarsson (2012) Viktigt, men inget för mig. Ungdomars identitetsbygge och attityd till naturvetenskap. ISBN:

978-91-7519-988-7 (Doctoral Dissertation) Linköping University

51. Pernilla Granklint Enochson (2012) Om organisation och funktion av människo-kroppens organsystem - analys av elevsvar från Sverige och Sydafrika.

ISBN 978-91-7519960-3 (Doctoral Dissertation) Linköping University

52. Mari Stadig Degerman (2012) Att hantera cellmetabolismens komplexitet - Meningsskapande genom visualisering och metaforer. ISBN 978-01-7519-954-2 (Doctoral Dissertation) Linköping University 
Studies in Science and Technology Education

ISSN 1652-5051

PontD

53. Anna-Lena Göransson (2012) The Alzheimer A $\beta$ peptide: Identification of Properties Distinctive for Toxic Prefibrillar Species. ISBN 978-91-7519-930-6 (Licentiate thesis) Linköping University

54. Madelen Bodin (2012) Computational problem solving in university physics education

- Students' beliefs, knowledge, and motivation. ISBN 978-917459-398-3 (Doctoral Dissertation) Umeå University

55. Lena Aretorn (2012) Mathematics in the Swedish Upper Secondary School Electricity Program: A study of teacher knowledge. ISBN 978-91-7459-429-4 (Licentiate thesis) Umeå University

56. Anders Jidesjö (2012) En problematisering av ungdomars intresse för naturvetenskap och teknik i skola och samhälle - Innehåll, medierna och utbildningens funktion. ISBN 978-917519-873-6 (Doctoral Dissertation) Linköping University

57. Thomas Lundblad (2012) Simulerad verklighet i gymnasieskolans fysik: en designstudie om en augmented reality simulerinmed socio-naturvetenskapligt innehåll. ISBN 978-917519-854-5 (Licentiate thesis) Linköping University

58. Annie-Maj Johansson (2012) Undersökande arbetssätt i NOundervisningen i grundskolans tidigare årskurser. ISBN 97891-7447-552-4 (Doctoral Dissertation) Stockholm University

59. Anna Jobér (2012) Social Class in Science Class. ISBN 97891-86295-31-8 (Doctoral Dissertation) Malmö University

60. Jesper Haglund (2012) Analogical reasoning in science education - connections to semantics and scientific modeling in thermodynamics. ISBN 978-91-7519-773-9 (Doctoral Dissertation) Linköping University

61. Fredrik Jeppsson (2012) Adopting a cognitive semantic approach to understand thermodynamics within science education. ISBN 978-91-7519-765-4 (Doctoral Dissertation) Linköping University 
Studies in Science and Technology Education

ISSN 1652-5051

\section{ronk}

62. Maria Petersson (2012) Lärares beskrivningar av evolution som undervisningsinnehåll i biologi på gymnasiet.ISBN 97891-7063-453-6 (Doctoral Dissertation) Karlstad University

63. Henrik Carlsson (2012) Undervisningsform, klassrumsnormer och matematiska förmågor. En studie av ett lokalt undervisningsförsök för elever med intresse och fallenhet för matematik. ISBN 978-91-86983-89-5 (Licentiate thesis) Linnaeus University)

64. Anna Bergqvist (2012) Models of Chemical Bonding. Representations Used in School Textbooks and by Teachers and their Relation to Students' Understanding. ISBN 978-91-7063463-5 (Licentiate thesis) Karlstad University

65. Nina Kilbrink (2013) Lära för framtiden: Transfer i teknisk yrkesutbildning. ISBN 978-91-7063-478-9 (Doctoral Dissertation) Karlstad University

66. Caroline Larsson (2013) Experiencing Molecular Processes. The Role of Representations for Students' Conceptual Understanding. ISBN 978-91-7519-607-7 (Doctoral Dissertation) Linköping University

67. Anna-Karin Carstensen (2013) Connect Modelling Learning to Facilitate Linking Models and the Real World through Labwork in Electric Circuit Courses for Engineering Students ISBN 978-91-7519-562-9 (Doctoral Dissertation) Linköping University

68. Konferensproceeding: 10-year Anniversary Meeting with the Scientific Committee

69. Marie Bergholm (2014) Gymnasieelevers kommunikativa strategier i matematikklassrummet. En fallstudie av ett smågruppsarbete om derivata ISBN 978-91-7519-306-9 (Licentiate thesis) Linköping University

70. Ingrid Lundh (2014) Undervisa Naturvetenskap genom Inquiry - En studie av två högstadielärare. ISBN 978-91-7519-285-7 (Licentiate thesis) Linköping University 
Studies in Science and Technology Education

ISSN 1652-5051

Ponts

71. Nils Boman (2014) Personality traits in fish - implications for invasion biology

ISBN:978-91-7601-097-6 (Licentiate thesis) Umeå University

72. Torodd Lunde (2014) När läroplan och tradition möts - lärarfortbildning och syften med undersökande aktiviteter inom den laborativa NO-undervisningen i grundskolans senare del.

ISBN: 978-91-7063-577-9 (Licentiate thesis) Karlstad University

73. Martin Eriksson (2014) Att ta ställning - gymnasieelevers argumentation och beslutsfattande om sociovetenskapliga dilemman. ISBN 978-91-7063-588-5 (Licentiate thesis), Karlstad University

74. Annalena Holm (2014) Mathematics Communication within the Frame of Supplemental Instruction. Identifying Learning Conditions. ISBN 978-91-7623-112-8 (Licentiate thesis) Lund University

75. Daniel Olsson (2014) Young people's 'Sustainability Consciousness' - Effects of ESD implementation in Swedish schools. ISBN 978-91-7063-594-6. (Licentiate thesis) Karlstad University

76. Marlene Sjöberg (2014) Möjligheter I kollegiala samtal om NO-undervisning och bedömning.

https://gupea.ub.gu.se/handle/2077/24063 (Licentiate thesis) Gothenburg University.

77. Teresa Berglund (2014) Student 'Sustainability Consciousness' and Decision-Making on Sustainability Dilemmas. Investigating effects of implementing education for sustainable development in Swedish upper secondary schools. ISBN 97891-7063-599-1 (Licentiate thesis) Karlstad University

78. Elisabet Mellroth (2014) High achiever! Always a high achiever? A comparison of student achievements on mathematical tests with different aims and goals. ISBN 978-917063-607-3 (Licentiate thesis) Karlstad University 
Studies in Science and Technology Education ISSN 1652-5051

FontD

79. Jenny Green (2014) Elevers användande av formativ återkoppling i matematik. ISBN 978-91-7519-164-5 (Licentiate thesis) Linköping University 